
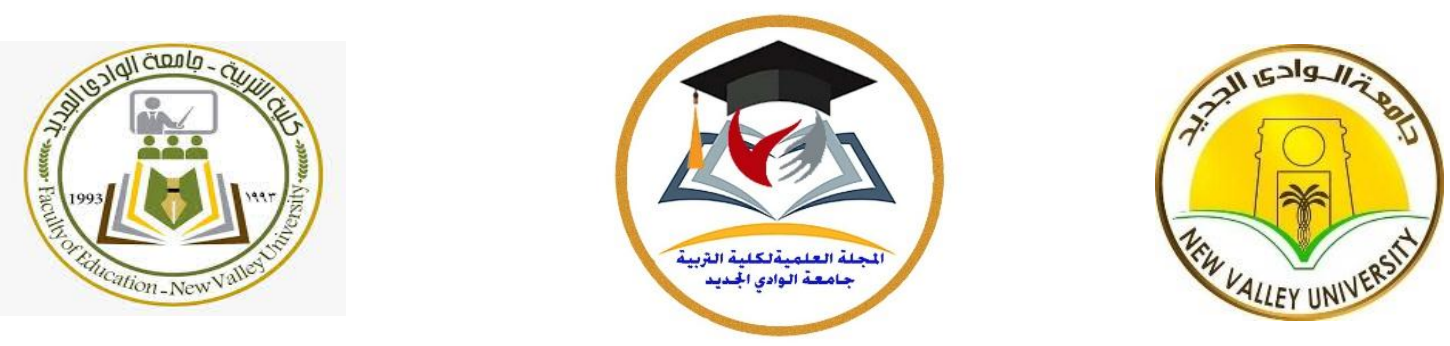

قسم أصول التربية

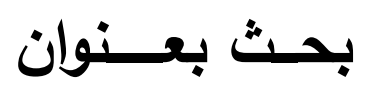

\title{
دور مؤسسات التعليم الثانوي في تحقيق التربية الأمنية "دراسة ميدانية بمحافظة الوادي الجديد"
}

\author{
إعداد \\ راندا منير مهدي \\ حاصلة على بكالوريوس التجارة شعبة "محاسبة" \\ جامعة قناة السويس
}

أ.م.د/ اماني محمد الثريف

أستاذ أصول التربية المساعد

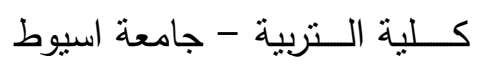

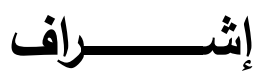

أ.د// ناصر محمد عامر

أستاذ التربية المقارنة والإدارة التعليمية

وعميد كليةالتربية - جامعة الوادي الجديد

$$
\text { Tr.r. }
$$


يعد الأمن هاجس الثعوب على مر العصور ، فما من أمة إلا وتسعى إلى تحقيق أمنها بشنى بإنى

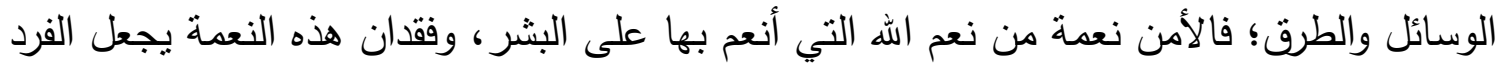
فريسة للمخاوف التي تتعكس على شنى جوانب الحياة.

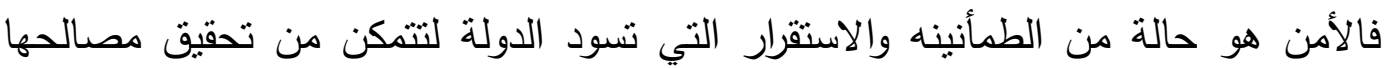

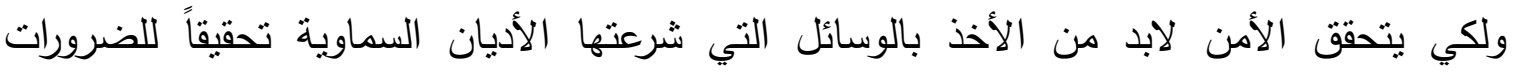

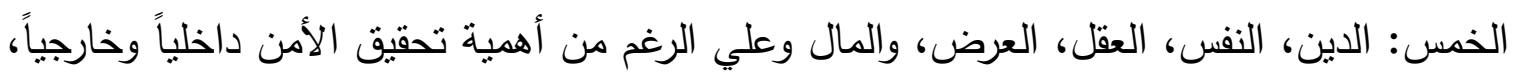

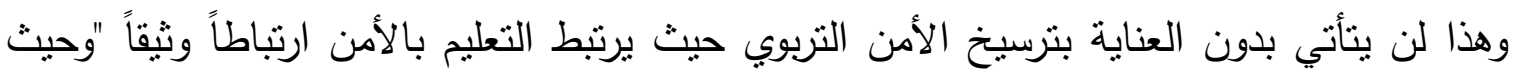

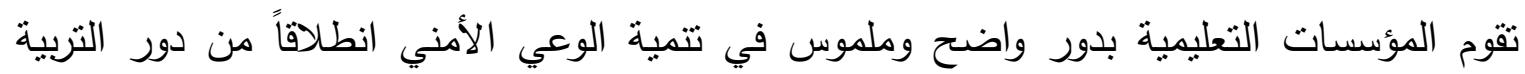

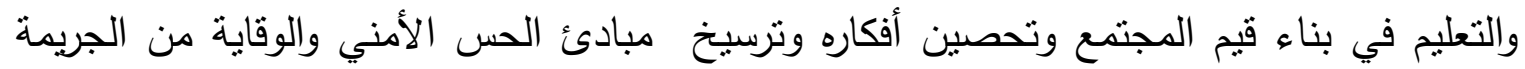

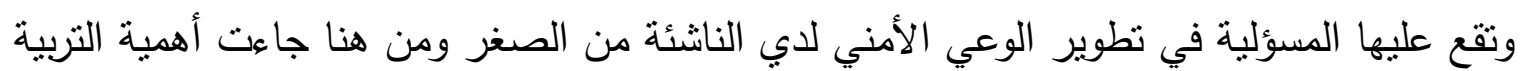

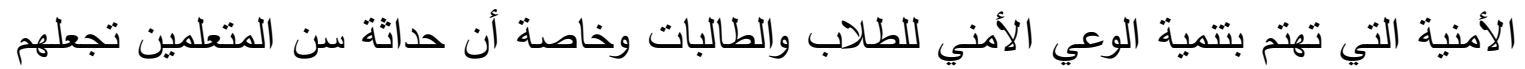

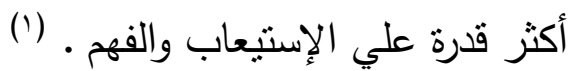

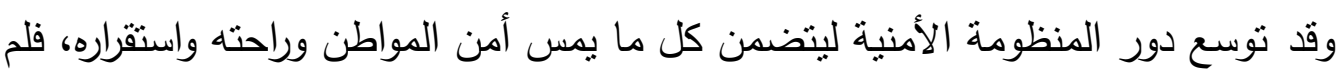

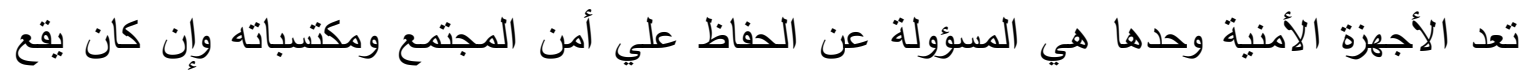

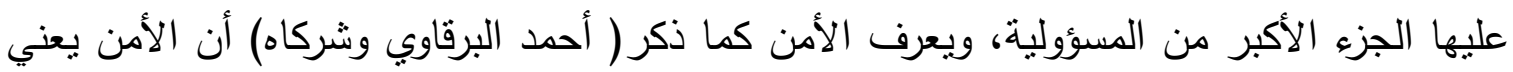

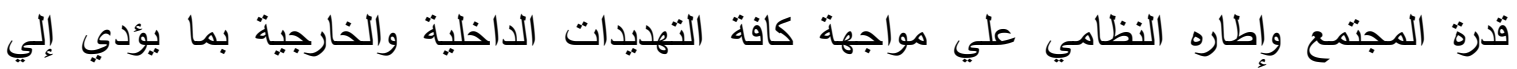

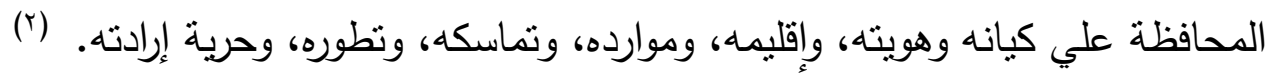

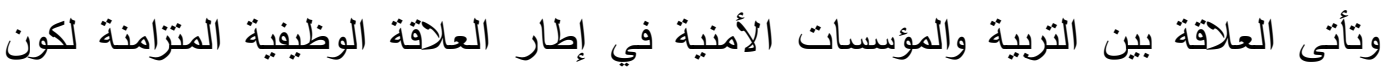

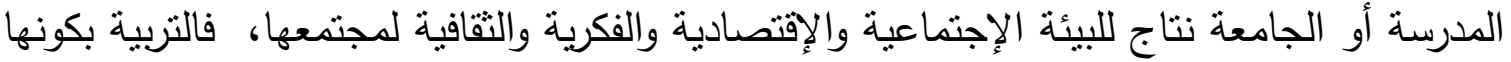

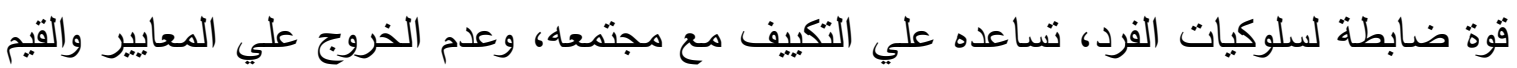

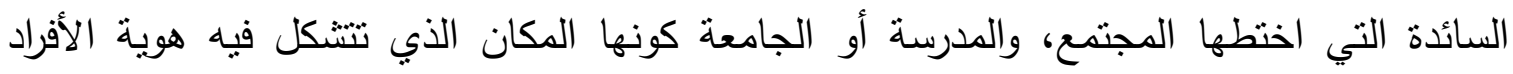

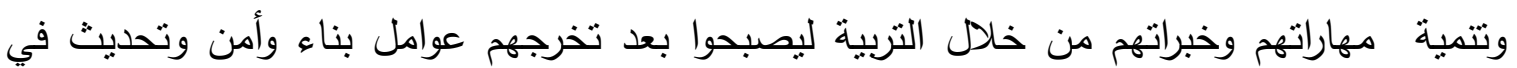

(') تركي العتيبي ، إسهامات الإدارة المدرسية في تنمية الوعي الأمني، دراسة تطبيقية علي مدارس التعليم العام الثانوي الحكومي

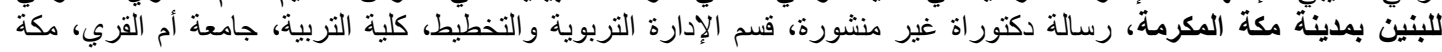

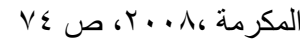

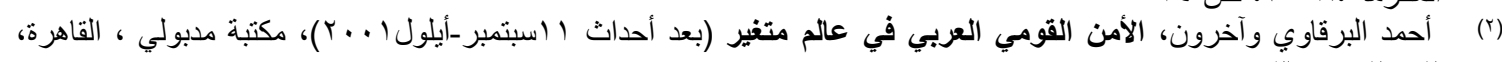

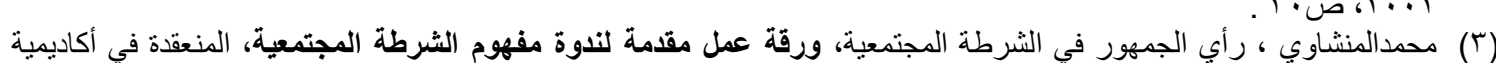

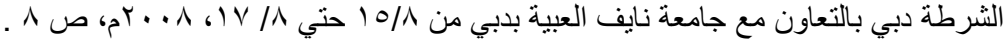


كما أكدت (آمال محمد إبراهيم،9 (ب) علي"أن المؤسسات التربوية علي كافة أثنكالها المنبع الرئيسي الذي يكسب الطالب من خلاله العلم والمعرفة وتتمو مهاراته وتتطور سلوكياته

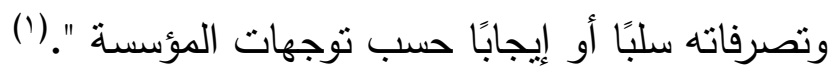

ويمكن القول أن الحاجه إلي التربية الأمنية وتطبيقها في المؤسسات التعليمية تدعم الأمن

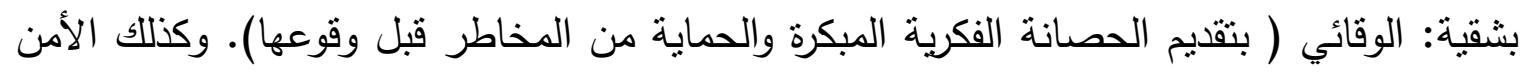

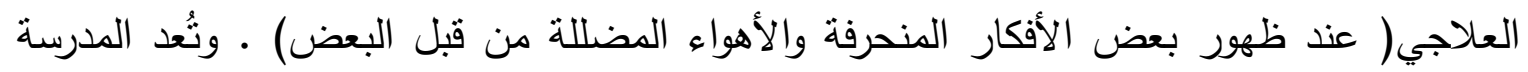

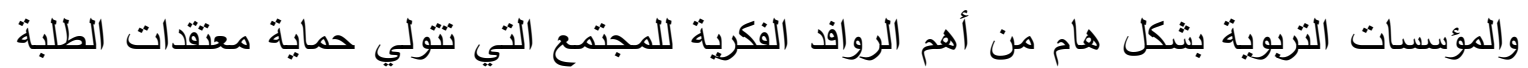

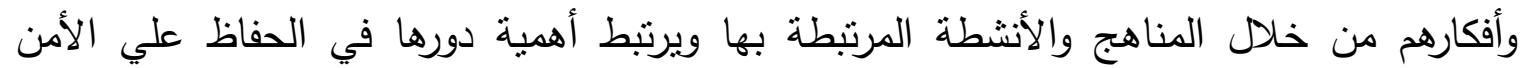
الفكري، كونها تضم فئة من أهم فئات المجتمع، وثروة من أغلي الثروات للأمم ألا وهي الطلبة .

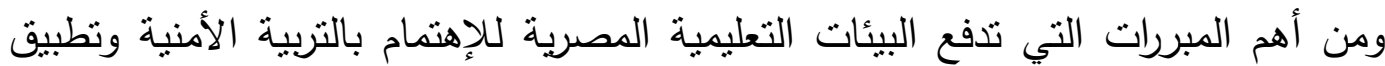

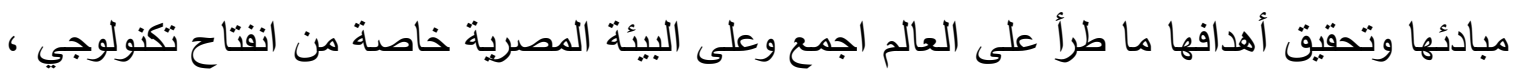
دفع الصغار والكبار للإنخراط في ثقافات غير مطابقة للعادات والتقاليد المصرية تولد عنها سلوكيات منحرفة وتتمر بين الصغار والكبار، وهذه السلوكيات المنحرفة من عنف وشللية وانحراف اخلاقي عبر مواقع التواصل الإجتماعي ينتشر ويتوغل في الددارس المصرية جميعها. و من أهم المراحل التعليمية التي ينبغي التركيز عليها هي مرحلة التعليم الثانوي بإعتبارها محضنا لجيل الثباب المقبل علي الحياة بكل ما فيها من خير وشر ، حيث تتميز هذه المرحلة بتحولات فكرية تتسم بالاضطراب وكثرة التساؤلات والرغبة في اكتثاف ماهو غامض او متتاقض ، مما يستلم العمل علي تحقيق الطمأنينة والأمان في نفوسهر ، ومخاطبة عقولهم ووجدانهم خطابا

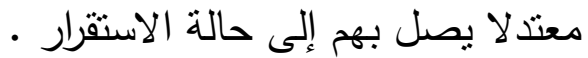
ولعل ظهور بعض المخاطر بين طلاب المرحلة الثانوية بمحافظة الوادي الجديد مؤشر علي ضعف تحقق التربية الأمنية لدي الطلاب وضعف في تحقيق الحصانه الأمنية التربوية لهوُلاء

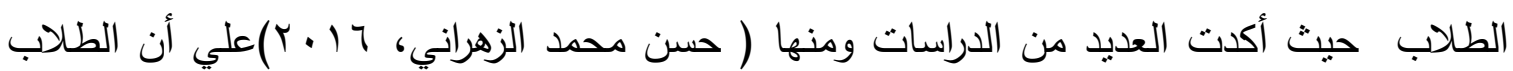

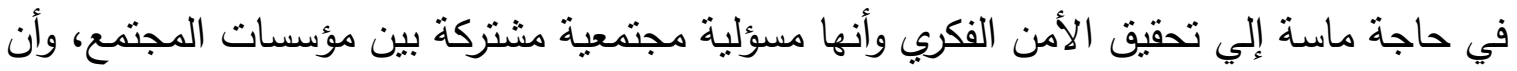

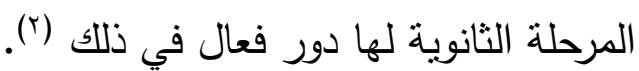
كما أن التربية في عمومها تؤدي دورًا مهمًا في الحفاظ علي نقافة دورة المجتمع العامة، ونقلها عبر

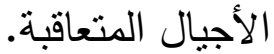

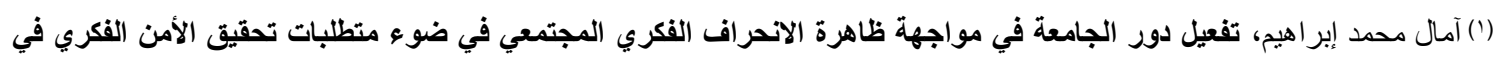

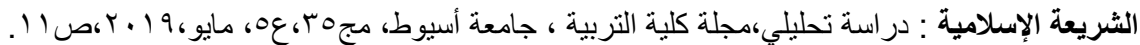

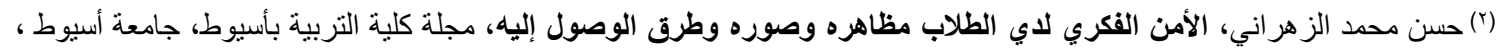

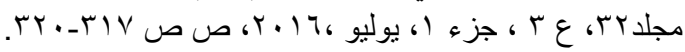


كذلك تعمل علي تتمية وعي أفراد المجتم، كما أن لها دورًا في تطوير هذه الثقافة وتجديدها

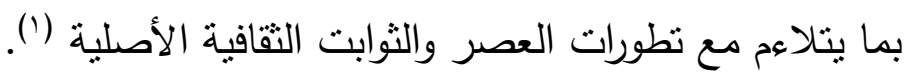

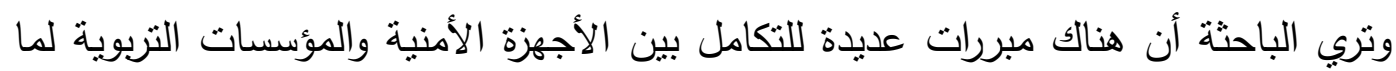

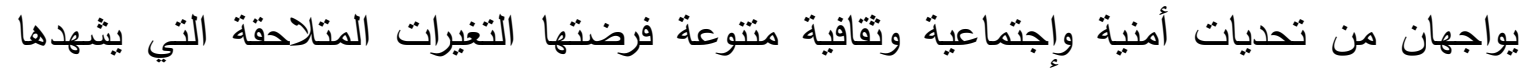
المجتمع المصري في مختلف المجالات لعل من أهمها التيارات الفكرية المنطرفة والحملات

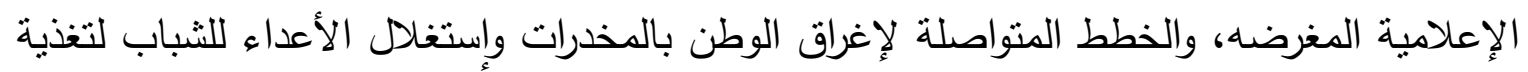

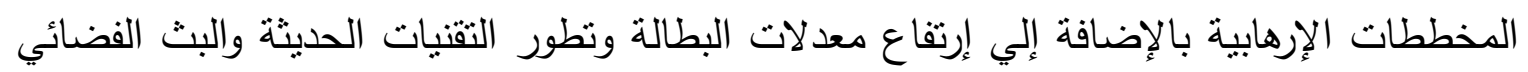
وما يترتب عليها من أخطار مادية ومعنوية وتقرض هذه التحديات تكاتف الجهود لوقاية الثريحة

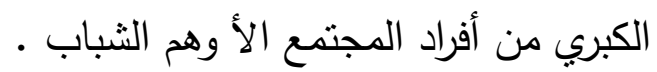
وتأسيساً علي ما سبق فإن الدراسة الحالية تسعى إلي التحقق من دور مدارس التعليم الثانوي في تحقيق النزبية الأمنية

\section{مشكلة الاراسة}

على الرغم من أن مفهوم التربية الأمنية أضحى مفهوماً تربوياً دولياً شائعاً، وامتدت تطبيقاته في كثير

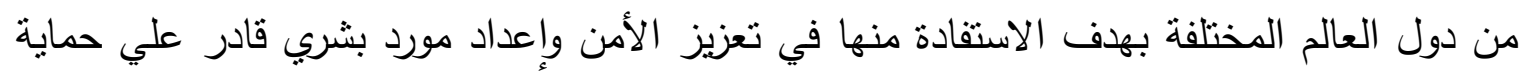

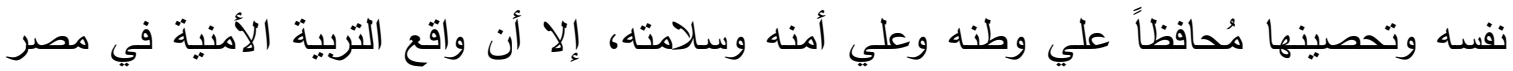

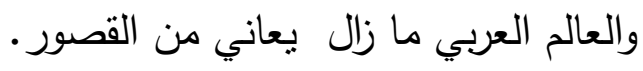

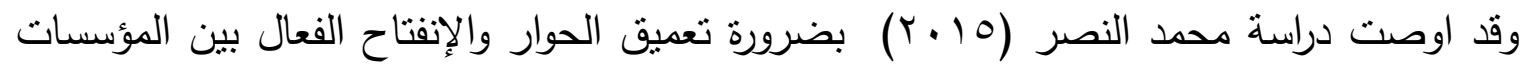
التربوية والمؤسسات الأمنية فالأمن مسؤولية يجب أن يضطلع بها الجميع وليس المؤسسات الأمنية

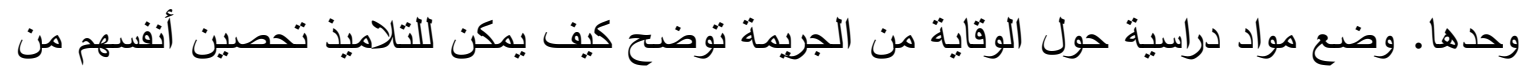

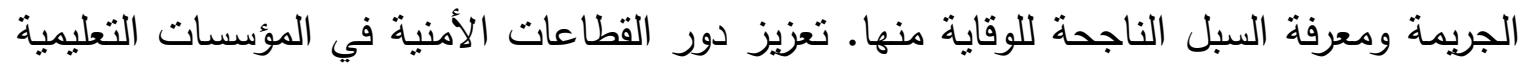

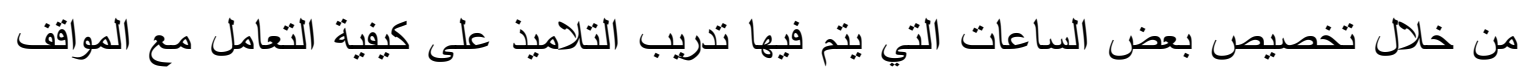
المختلفة وذلك تحت إنثراف متخصصين في التربية والإجتماع وعلم النفس وكذلك تأهيل رجال الأمن لأن

تربوياً للتعامل مع المواقف التعليمية المختلفة. (ץ) كما دعت دراسات وندوات ومؤتمرات محلية وعربية عدة إلي توطيد العلاقة بين القطاعات الأمنية والتعليمية بما يسهم من تحقيق التكامل الفعال بينها وبناء شراكة مستدامه بين وزارة التربية والتعليم

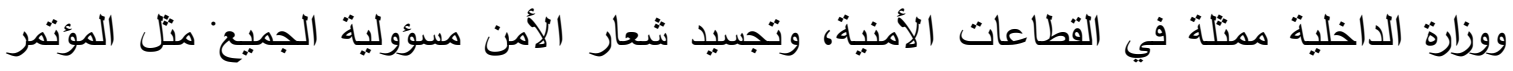

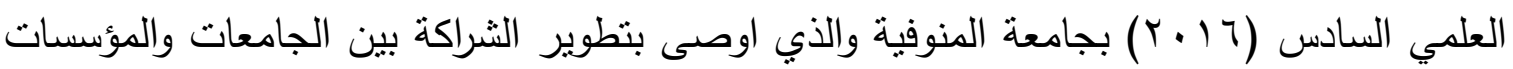

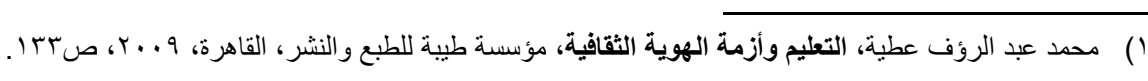
(r) محد النصر حسن، روية تريوية مقترحة لمتطلبات تحقيق التربية الأمنية بمرحلة التعليم الإبتدائي مجلد ع، العدد (rr) ص ص ع ـ T-7097. . 
التعليمية، ومؤسسات المجتمع المدني في تعزيز الأمن للطلاب من خلال البرامج وورش العمل

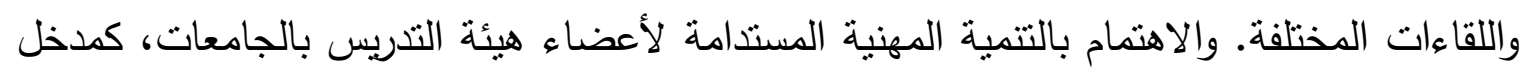

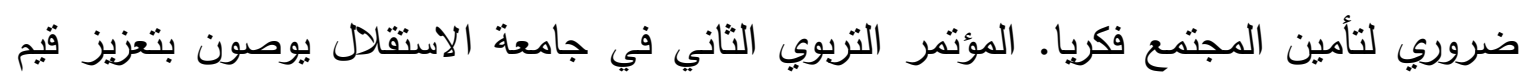

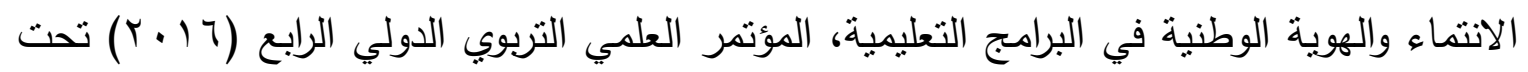

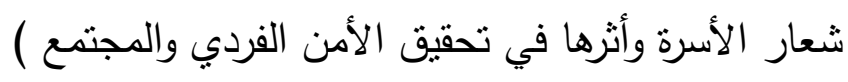

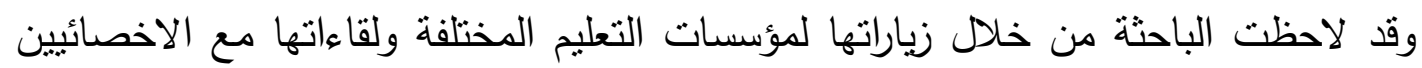

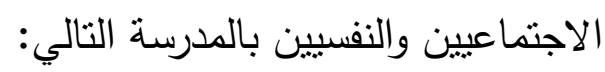
1- قيام بعض المتعلمين في المراحل المختلفة بأعمال عنف وتخريب مدفوعة بالإحباط، وأدى ذلك بلك الكين

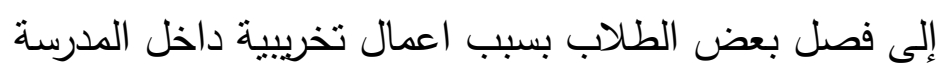
r- التطرف الفكري والخلقي الثنائع في بعض المدارس خاصة الددارس الثانوية والذب بعتبر نواة للارهاب والنطرف الديني ب- المظاهر السلوكية للمراهقة هي أهم مايميز الطالب في مرحلة التعليم الثانوي ، حيث تتسم ردود

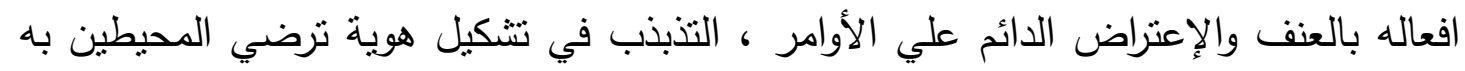

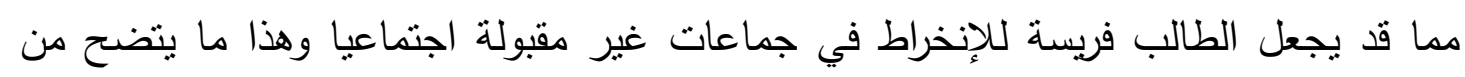

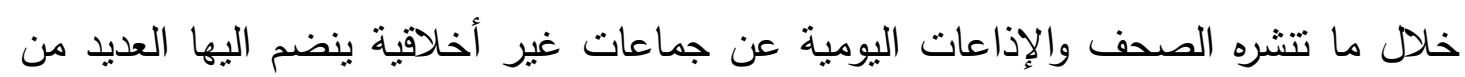
طلاب المرحلة الثانوية ـ بناءاً على ماسبق ، تحاول الدراسة الحالية استقصاء دور المدارس الثانوية في تحقيق التربية الأمنية

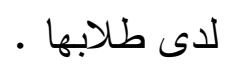
أسئلة الدراسة فلابهة

1- ما الإطار المفاهيمي للتربية الأمنية ؟

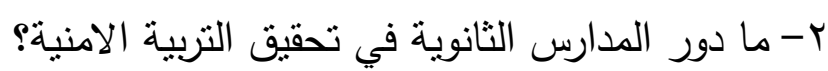

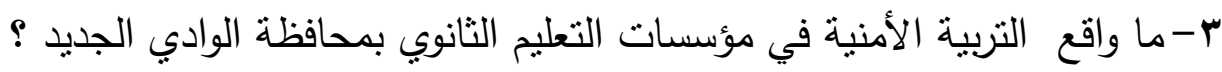
ـ - ما التوصيات التي يمكن أن تسهم في تعزيز دور مؤسسات التعليم الثانوي في تحقيق التربية

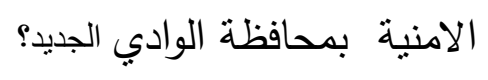
أهداف الدراسة تسعي الدراسة الحالية إلى:1- إلقاء الضوء على الإطار الدفاهيمي للتربية الأمنية في مؤسسات التعليم الثنانوي. r- التعرف على دور المدارس الثانوية في تحقيق التربية الأمنية. 
r- رصد الواقع الفعلي التربية الأمنية في مؤسسات التعليم الثنانوي بمحافظة الوادي الجديد، وأهم

$$
\text { المعوقات التي تواجهه. }
$$

ع- تقديم التوصيات اللازمة لتعزيز دور مؤسسات التعليم الثانوي في تحقيق التربية الأمنية بمحافظة الوادي الجديد.

أهمية الدراسة:

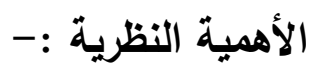

- تأخذ الدراسة أهميتها النظرية من أهمية الأمن في حياة الأفراد والمجتمعات، والدور المؤثر الذي تقوم

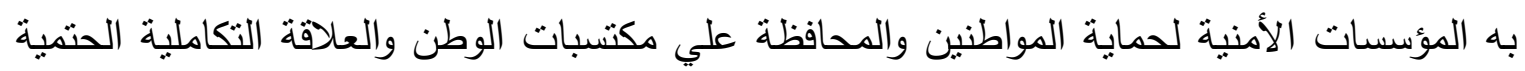
بين المؤسسات الأمنية والمؤسسات التربوية.

من المؤمل أن تعرض الدراسة تحليلا نظريا لدور المدارس الثانوية في تحقيق التربية الأمنية

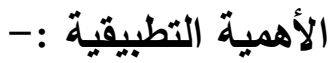

1- تزويد الهيئات والجهات التعليمية بجوانب القصور في دور المدارس الثانوية في تحقيق التربية الأمنية. r- تقديم عدد من التوصيات التي يمكن من خلالها تعزيز دور المدارس الثانوية في تحقيق التربية

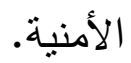

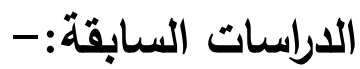

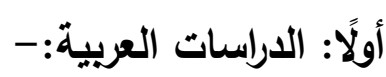

1 - دراسة (السلطان، 9 . . ץ) (1) "التربية الأمنية وإمكانية تطبيقها في المؤسسات التعليمية"

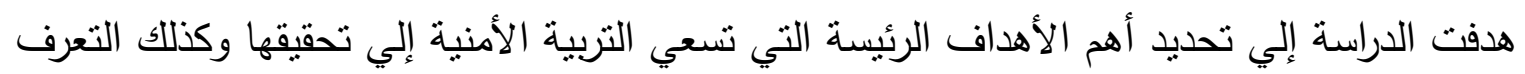

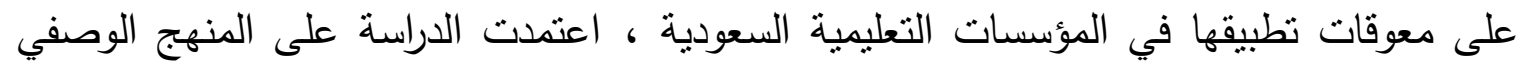

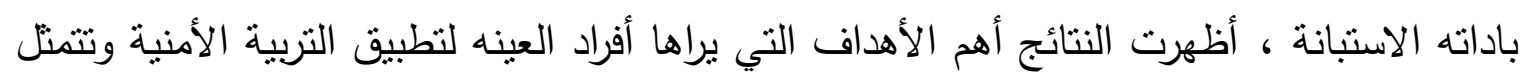

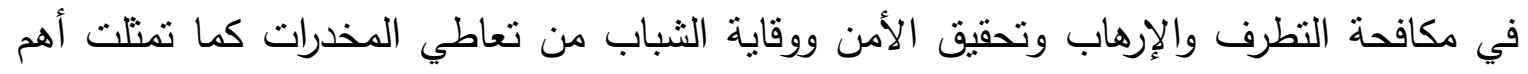
المعوقات في ضعف التتسيق بين المؤسسات الأمنية وكثرت المهام المطلوبة بالمدرسة.

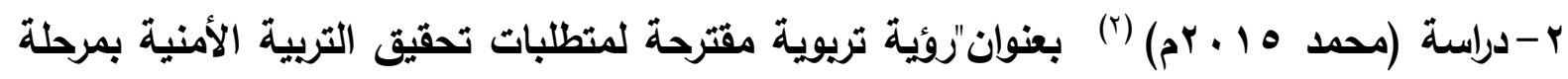

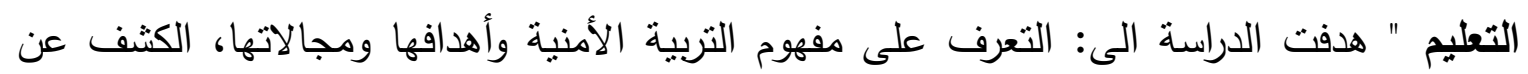

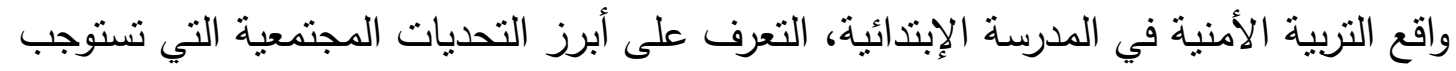


تفعيل التربية الأمنية في الددرسة ، تحليل أهم المعوقات التربوية التي نواجه التربية الأمنية لتلاميذ

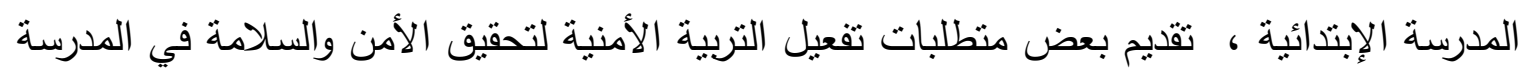

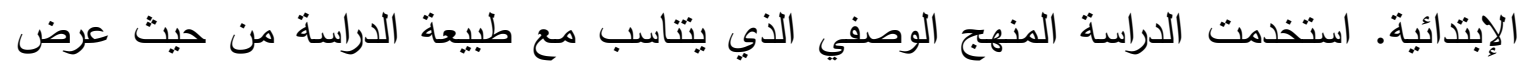

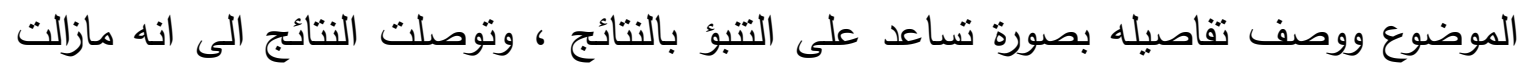

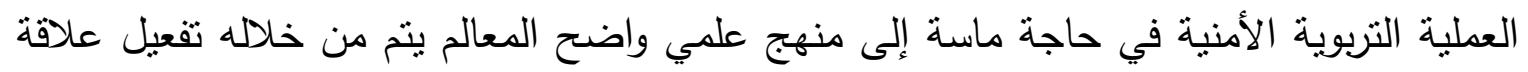

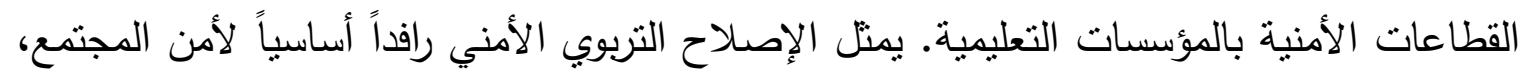

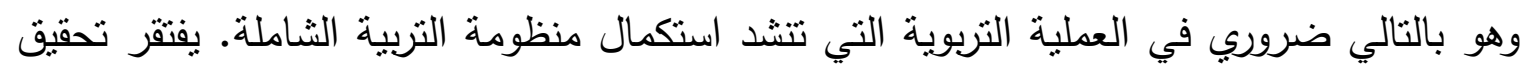
الأمن المدرسي إلى التخطيط الواعي والواقعي من جانب القائمين على التعليم في مختلف المراحل

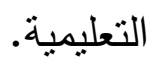

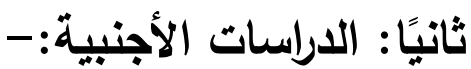
1-دراسة Bradshaw,s (2011) (') بعنوان تصميم منهج دراسي قائم علي الأمن الداخلي في

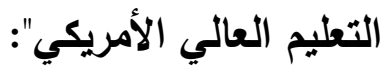

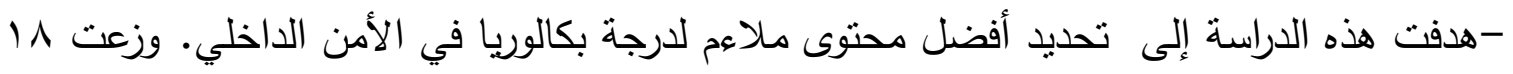
من الدراسات الاستقصائية عن طريق البريد، و(r/) عن طريق البريد الإلكتروني، بالاضافة الي لئي

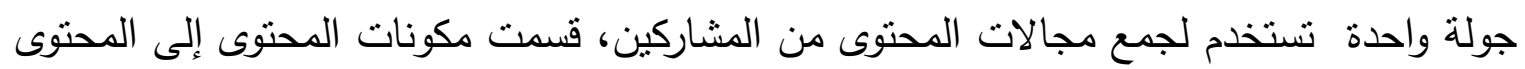
الرئيسي، وطلب من المشاركين لتصنيف مكونات المحتوى الرئيسية باستخدام مقياس Likert. بعد كل جولة، والوسائل والوسائط ونواتجها، أظهرت نتائج هذه الدراسة تسعة مجالات التي ستكون

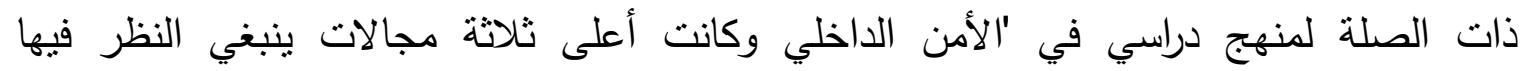

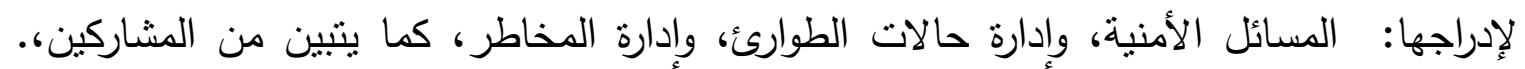

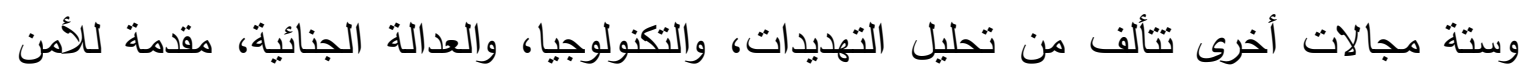

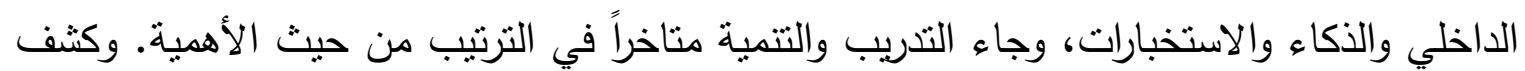

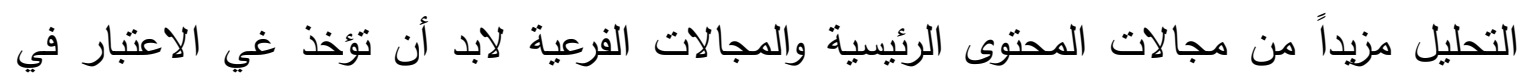
محتوى المناهج الدراسية. r-دراسة (2013Comp.) (ץ) بعنوان البرنامج الوطني للتربية الأمنية واحتياجاتها من الخدمات:

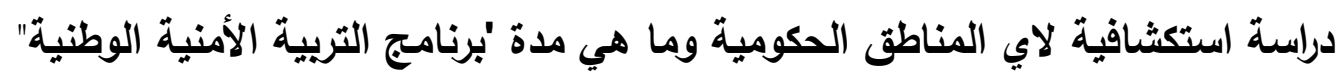

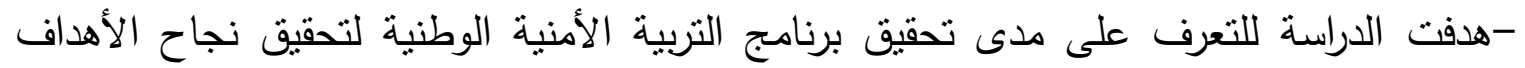

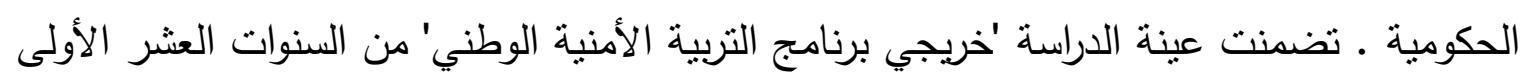

(1))Bradshaw, Chris William): Designing a homeland security curriculum in American higher education, Dissertation Abstracts International, Pro Quest 902491019 Ann Arbor, Texas, United States, 2011, P.15

(2) Comp, D. J.: The National Security Education Program and its service requirement: An exploratory study of what areas of government and for what duration National Security Education Program recipients have worked 2013). 
من البرنامج كوسيلة للإجابة على السؤال البحثي. أثتثت النتائج أن 'برنامج التربية الأمنية الوطنية

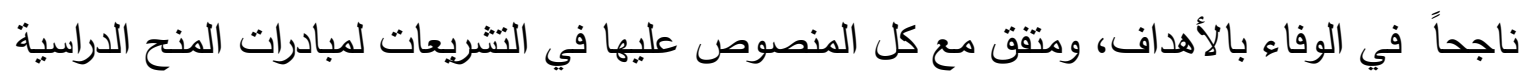
والزمالات الدراسية للبرنامج.

التعقبب على الاراسات السابقة

اتفقت معظم الدراسات السابقة المتعلقة بالتربية الأمنية علي أهمية التربية الأمنية، كما أكدت دور

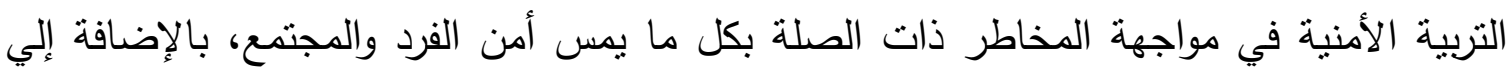

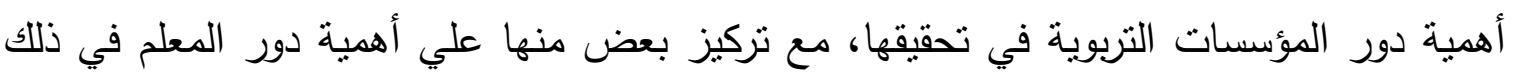
بإعتباره حجر الزاوية في العملية التعليمية .

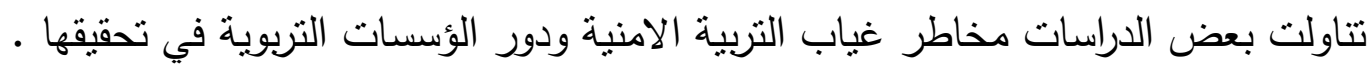

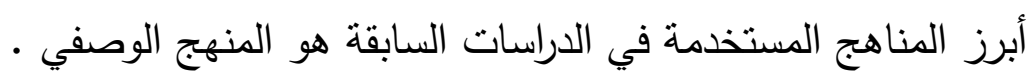

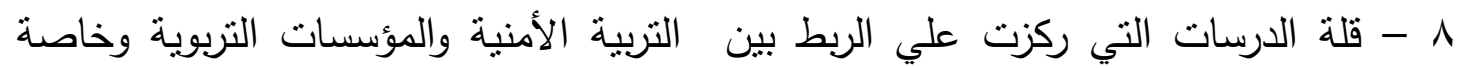

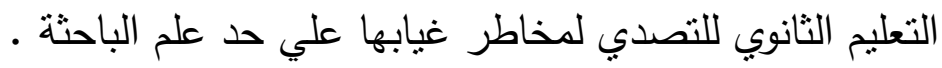

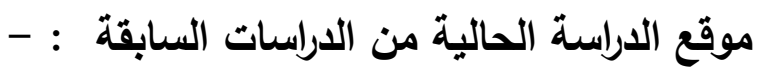
مما سبق تلخص الباحثة أوجه النتابة والإختلاف بين الدراسات السابقة والدراسة الحالية فيما يلي :

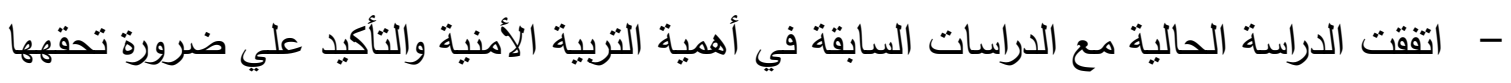

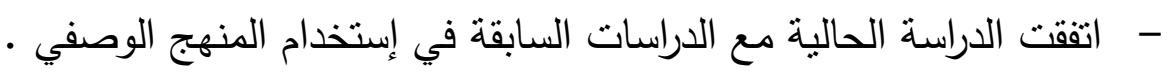
- اتفقت الدراسة الحالية مع الدراسات السابقة في الإعتماد علي الإستبانه كأداة لجمع البيانات . - متختلف الدراسة الحالية عن الدراسات السابقة في الآتي : - تباينت هذه الدراسات في حدودها المكانية ( السعودية _ فلسطين - كندا - أمريكا ) أما الحدود المكانية لهذة الدراسة فتتنتل في ( الولايات المتحدة الأمريكية - نيجيريا - استراليا- المملكة العربية

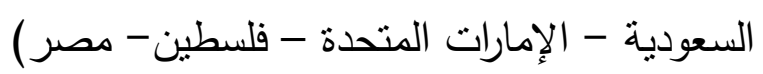
- - تتفرد هذه الدراسة في الإفادة من خبرات بعض الدول في النهوض بواقع التربية الأمنية في مؤسسات التعليم المصري. - كما اعتتت هذه الدرسة بدراسة واقع التربية الأمنية في التعليم الثانوي المصري وإمكانية النهوض به

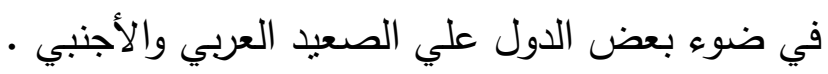

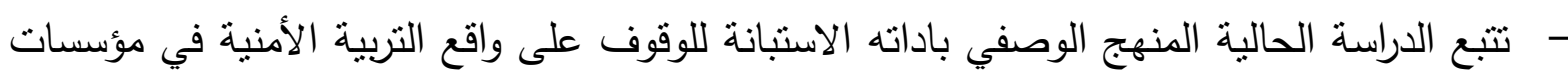
التعليم الثانوي الدصري والتي تعد في ضوء تحليلا للخبرات الدولية والعربية في مجال التربية الأمنية.

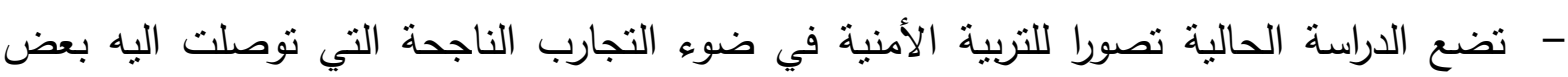
الدول وكذللك في ضوء ما نتجت عنه الدراسة الميدانية . 


\section{جوانب استفادة الدراسة الحالية من الدراسات السابقة : -}

- - بناء الإطار الفكري والنظري للاراسة .

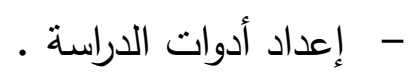

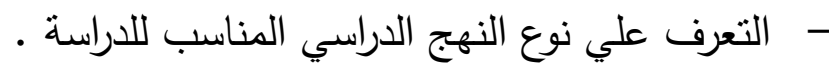

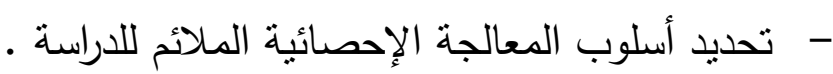

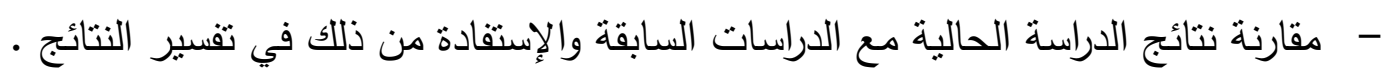

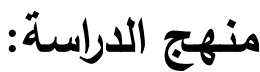

في ضوء طبيعة المثكلة وحدودها وأهدفها إتبع البحث المنهج الوصفي والذي يعتد علي وصف الظاهرة التعليمية وتحلياها ثقافياً والأسلوب التحليلي لها واستخدام الاستبانه والمقابلة المقننه كأحد

$$
\text { أدواته. }
$$

أدوات الدراسةة

- - إستخدمت الباحثة استبانه من إعدادها بهدف التعرف على واقع التربية الأمنية فى بعض التهابه المؤسسات التعليمية الثانوية في محافظة الوادي الجديد.

\section{حدود الدراسة}

أ - الحدود الموضوعية: اقتصرت الدراسة الحالية علي رصد واقع التربية الأمنية في مؤسسات التعليم الثانوي الدصري من حيث المفهوم ومبررات وآليات ومحتوى التطبيق فى ظل المستجدات

$$
\text { الراهنة . }
$$

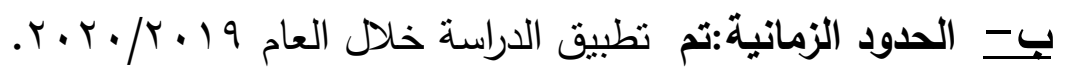
تـ- الددود المكانية: محافظة الوادي الجديد، الددارس الثانوية ، إدارات (الخارجة - باريس- الداخلة

$$
\text { - بلاط - الفرافرة). }
$$

ثـ- الدود البثرية: عينة من المعلمين والمعلمات فى المؤسسات التعليمية المختلفة بالمرحلة الثانوية بمحافظة الوادي الجديد.

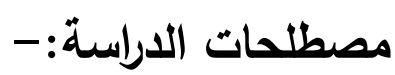

التربية الامنية: يعرفها (عبد الحميد، V. . Y) ('). بأنها "تعزيز الإنتماء الوطني والهوية الوطنية

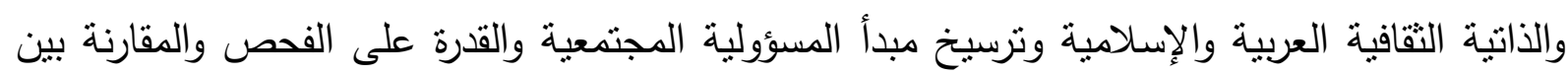




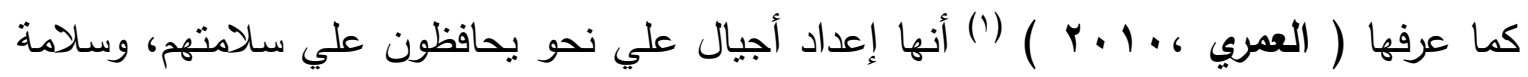

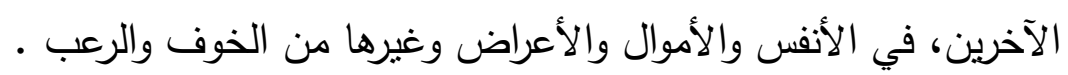

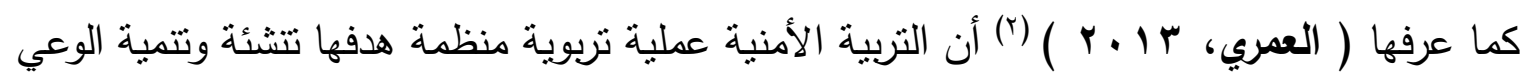

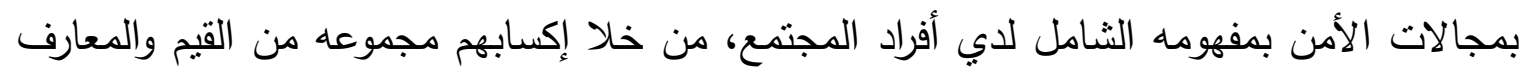

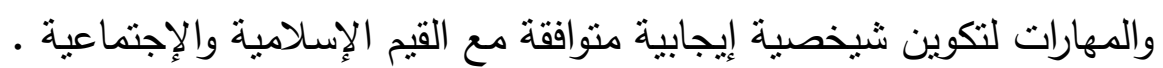

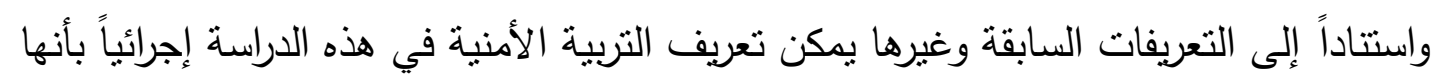

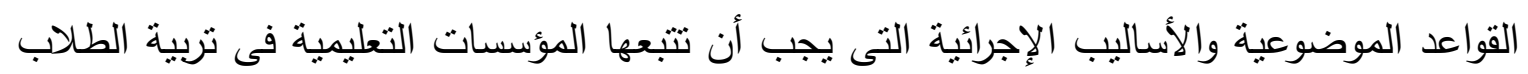

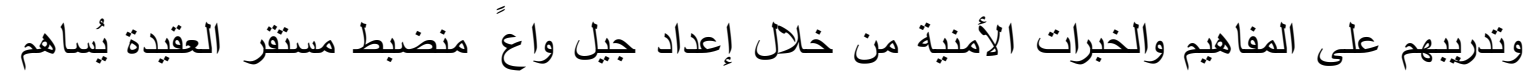
بفاعلية فى تأمين كيان المجتمع والدولة ضد الأخطار التي تهددها داخلياً وخارجياً وتأمين مصالحها

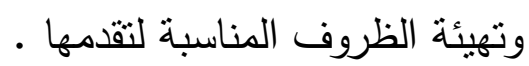

الإطار النظري للاراسة

يتضمن الإطار النظري للاراسة الإجابة عن التساؤلات الآتية:-

1- إ - الإطار المفاهيمي للتربية الامنية؟

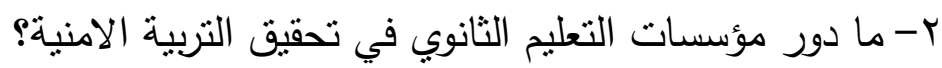
المحور الأول:- الإطار المفاهيمي للتربية الامنية:

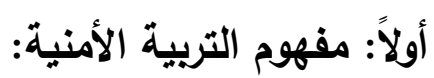

تعد التربية بمعناها العام جهود إنسانية مقصودة لإحداث تغييرات مرغوب فيها للفرد تتضمن

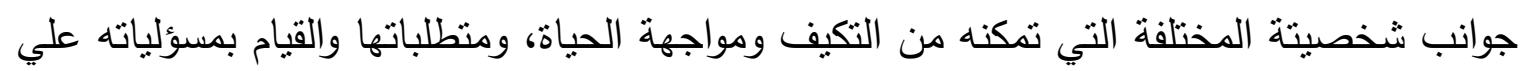

(ن) أكمل وجه.

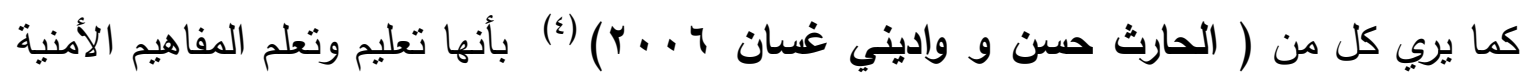

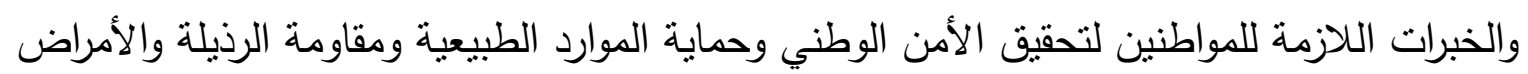
الإجتماعية . الإنات

(') محمد بن سعيد العمري، التربية الأمنية في الإسلام اصولها ودورها في تكوين الوعي بالأمن الإجتماعي لاي

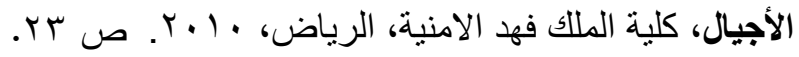

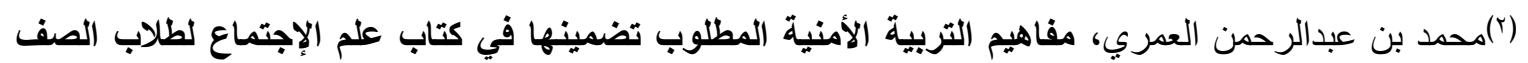

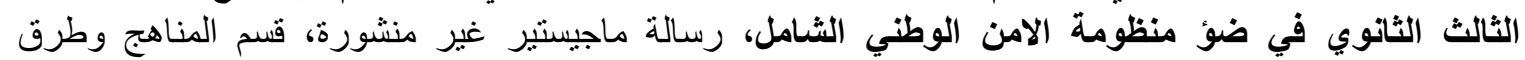

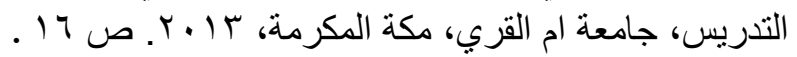

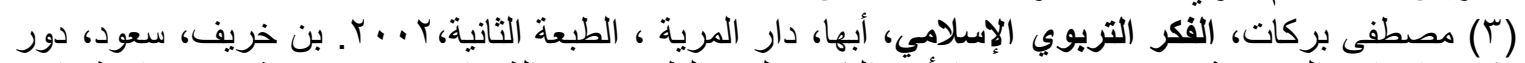

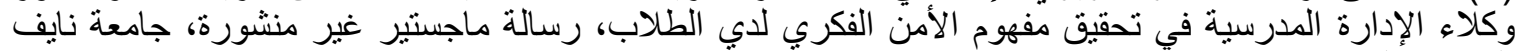

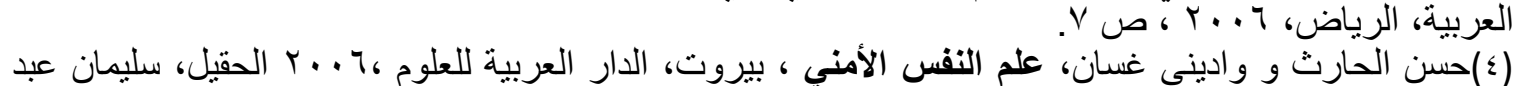

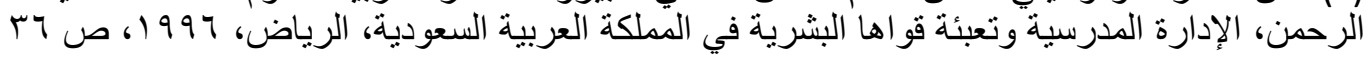


بينما يري (عبد اللطيف، رشاد V . . P) بأنها تدريب الطالب علي التصكك بالنظام في مختلف نواحي

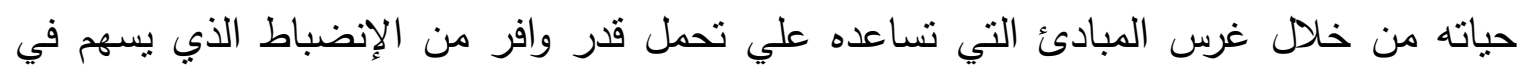

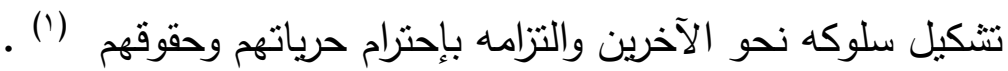

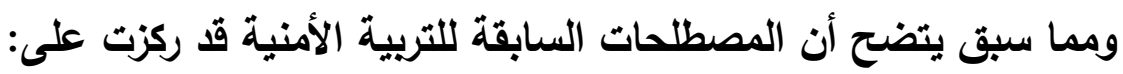

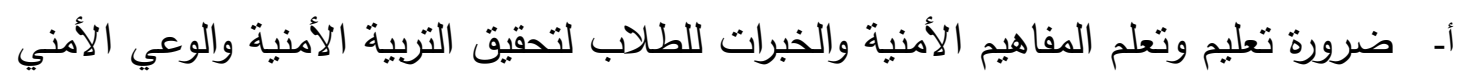
لإيهم. ب- غرس المبادئ الني تساعد الأفراد علي تحمل قدر وافر من الإنضباط الذي يسهم في تنكيل سلوكهم نحو الآخرين والتزامهم بإحترام حرياتهم وحقوقهم. ج- تقوية الروابط بين الفرد والبلد الذي ينتمي إليه.

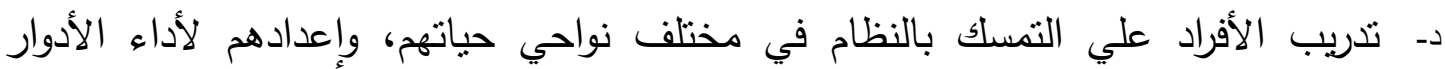
والواجبات والمسئوليات التي ينبغي عليهم القيام بها. وفي ضوء التعريفات السابقة يمكن تعريف التربية الأمنية بأنها عملية يتم بمقتضاها تزويد المتعمين بالمفاهيم والمبادىء الأمنية التي تسهم في تتكيل سلوكه، وتدربهم على الإنضباط، وتحميهم من

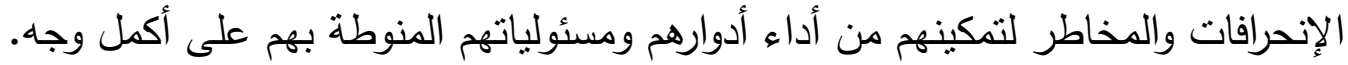
ثانياً: أهمية التربية الأنية الأمنية:

تسهم التربية الأمنية في بناء فكر الطلاب وإعدادهم لمواجهة الحياة بكافة أصنافها وضروبها وأطيافها، وانسجامه داخل نسيج المجتمع الددرسي؛ بشكل يتوافق فيه كل طالب مع أقرانه ومجتمعه بما لا يضّر بنفسه، ولا يضّر بمن يتعامل معه في مناحي الحياة المختلفة، ويمكن توضيح أهمية الهية

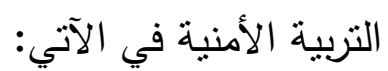
أ- حماية الفرد والمجتمعات من أخطار الجرائم والحوادث للعمل بكفاءة مطمئنين على حياتهم الاتهائ

\section{ومستقبلهم (ץ)}

ب- مكافحة جرائم الإختلاس وتهريب النقد وتزييف العملة التي تؤثز بشكل مباشر على الإقتصاد

الوطني وما يترتب عليه من إضعاف المقدرة المالية للدولة (r) .

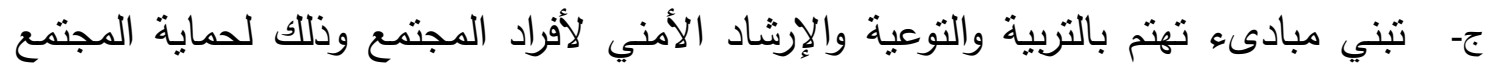
والتصدي إلى المخاطر التي تواجه. وأهم شريحة هي الطلاب لإثعارهم وتوعيتهم بخطورة

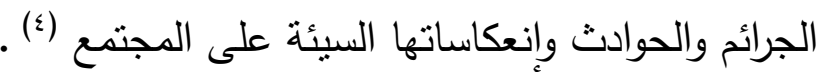

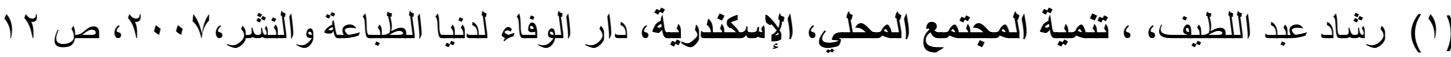

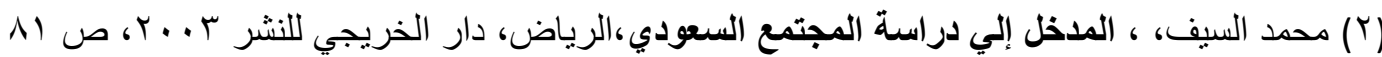

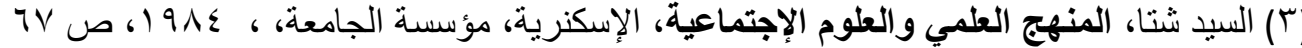

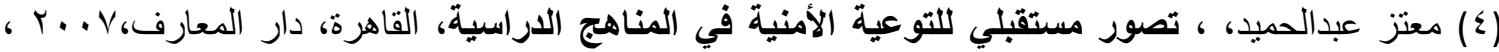


د- حاجة الإنسان للطمأنبة والسكينة والألفة والتي يترتب عليها سلامة الجنس البشري وهي لا

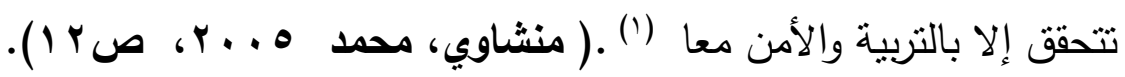

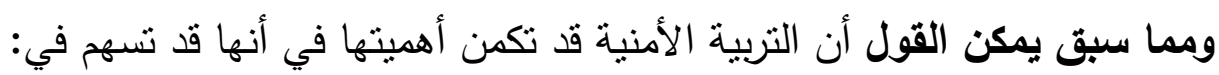

$$
\begin{aligned}
& \text { أ- عملية الضبط الإجتماعي. } \\
& \text { بـ الأمن الوقائي. } \\
& \text { ج- الحد من الجرائم والمخالفات. } \\
& \text { د- الإصلاح السلوكي. }
\end{aligned}
$$

هـ - الإسهام في عملية الوحدة الإجتماعية بين مواطني الدولة. و- إعداد أجيال المستقبل بحيث تسهم بشكل كبير في تحقيق الأمن الإجتماعي وبناء جيل

$$
\text { قادر على حماية نفسه وبناء وطنه. }
$$

ثالثًا: أهداف التربية الأمنية:

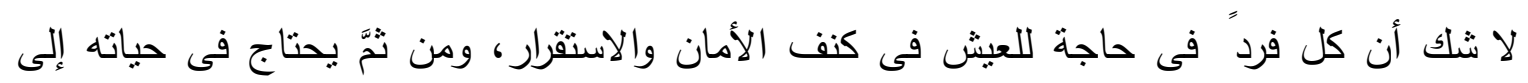

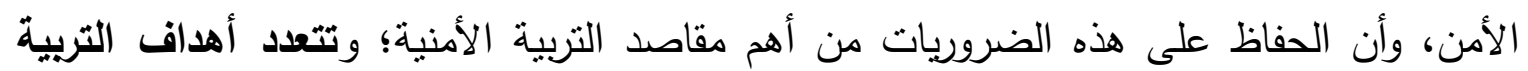
الأمنية، ويمكن إيجازها في النقاط التالية: أ- تربية المواطن وتتشئنه تتشئة قويمة وتعزيز الإنتماء الوطني والهوية الوطنية وتأصيل الإنتماء والولاء والمسئولية من خلال تعميق مفهوم الأمن الثشامل، وتعزيز الوعي الأمني ونئي

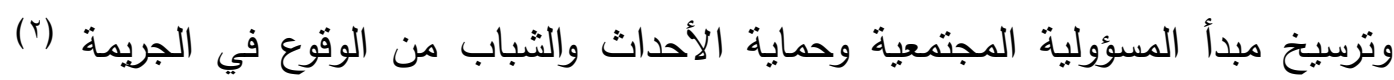

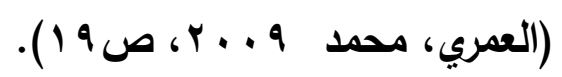

ب- تتكيل وجدان النشه وذلك بإعداد جيل طلاب واع ومحصن أمنياً وراسخ أخلاقياً يستطيع

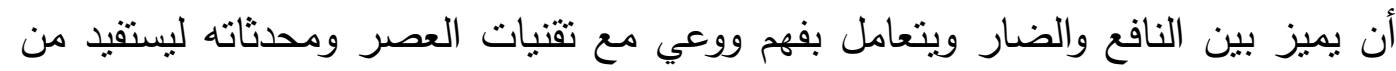

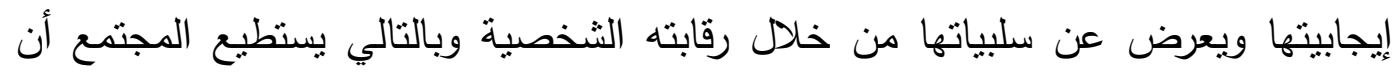
يحبط المخططات التي تنتهدف تدمير شبابه والمغريات التي نواجهه للإيقاع بأبنائه،

$$
\text { (r) وإيذائهم }
$$

ج- مساهمة الفرد في أمن نفسه وأمن مجتمعه وخلق الرقبب الذاتي الملازم لتعديل كل الأفعال

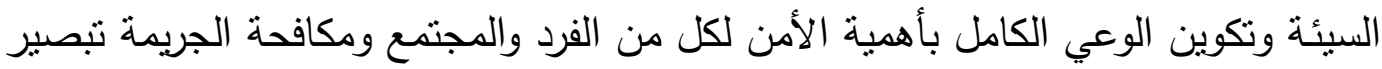
الفرد بحقوقه الأمنية وبواجباته وتمكينه من تطوير شخصيته وخاصة جوانبها الأمنية وكذلك اللك

(1) محمد منشاوي، رأي الجمهور في الثرطة المجتمعية، ورقة عمل مقدمة لندوة مفهوم الثرطة المجتمعية

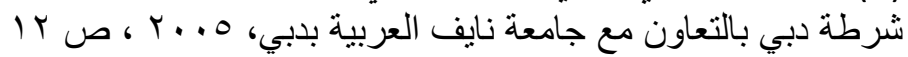

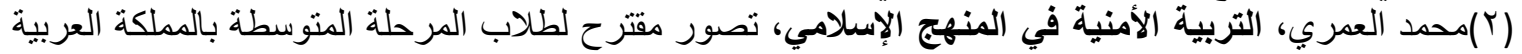

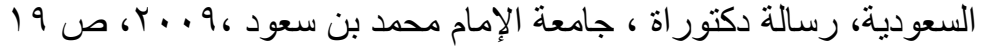

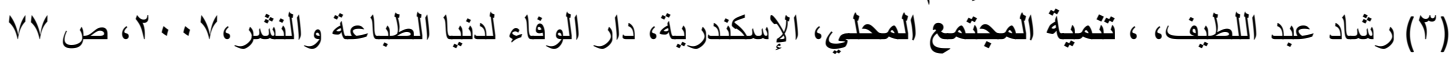


تحقيق الإخاء الإنساني والدعوة إلى التعاون بين الناس على الخير والحق والإصلاح

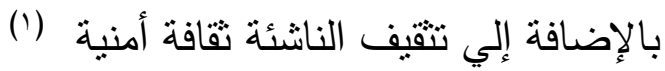
دـ قيام علاقات إجتماعية على أساس متين من التراحم والمودة والإثبار والتضحية والعفو عند

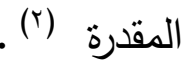

\section{ومما سبق تخلُص الباحثة على أن التربية الأمنية قد تهدف إلي:}

أ- تتمية المفاهيم الأمنية لاى الطلاب والحث على احترام القانون والنظام العام .

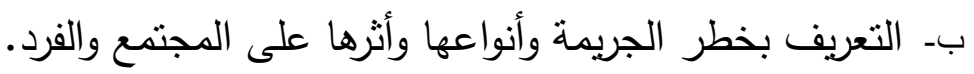
ج- مكافحة الجريمة والوقاية من الإنحراف.

دـ التوعية بأساليب المنحرفين والمجرمين في إرتكاب الجرائم المختلفة.

هـ - تعزيز مفهوم الأمن مسؤولية الجميع.

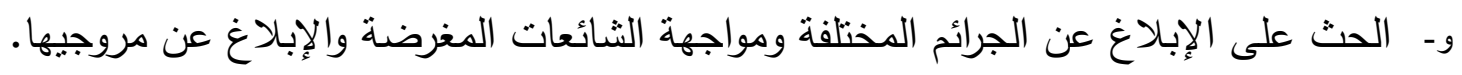

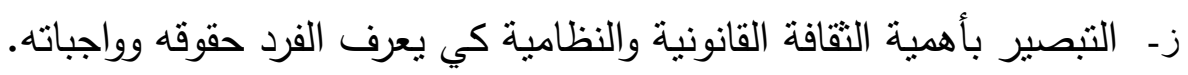
ح- تحقيق الأمن الوقائي لمواجهة الجريمة. طـ ضمان إستقرار حياة الفرد وإطمئنانه على ضرورات لإنهات حياته مما يضمن له حياة آمنة هانئة مستقرة.

ي- إستقرار المجتمع ودعمه لمقومات الأمن والتتمية مما يكفل تأمين حاجات الفرد والقدرة على حماية مصالحهم.

رابعاً: مخاطر وأضرار غياب التربية الأمنية: ان غياب التربية الأمنية تتضح آثارها في النقاط التربة الانية: التالية:

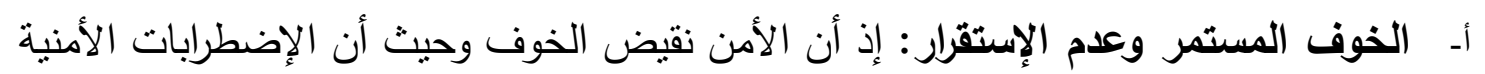

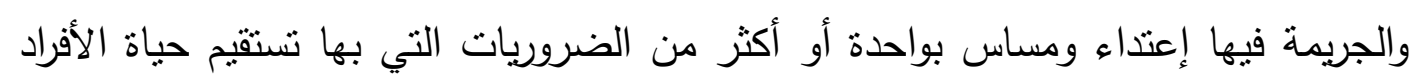

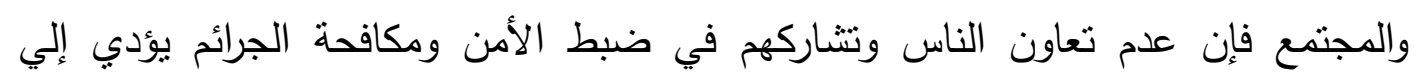

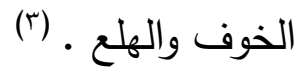
بـ تراجع التنمية البشرية والحضارية أو إنعدامها: حيث أن التتمية الثاملة تحتاج إلي العامل

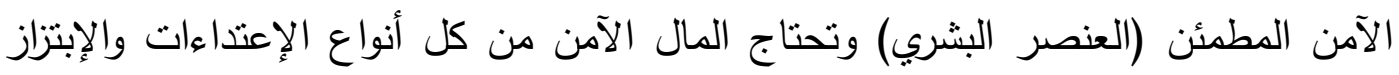

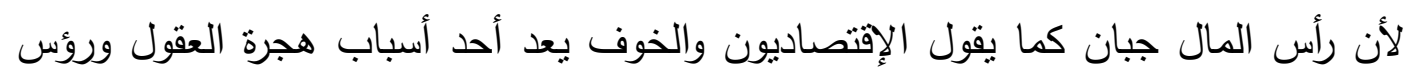

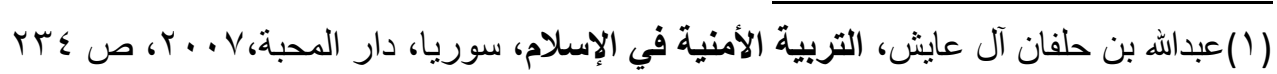

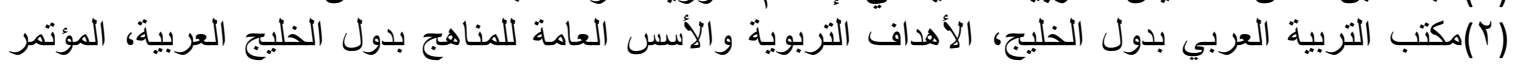

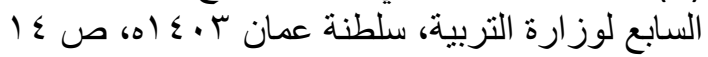

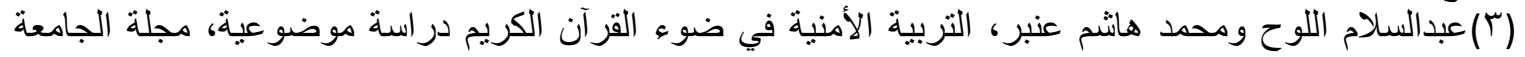

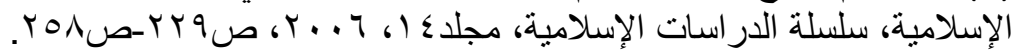


الاموال خارج البلاد نحو البلاد الاكثر امنًا وإستقرارًا وكل ذلك أدي إلي إستمرار التخلف في التي

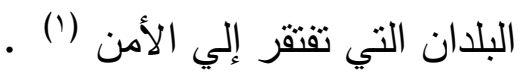
ج- تفاقم الجرائم بثتي أنواعها: لأن الوعي المترتب علي تربية الأفراد تتمية أمنية بمثل درعًا واقيًا دون إنزلاقهم في مهاوي الجريمة.

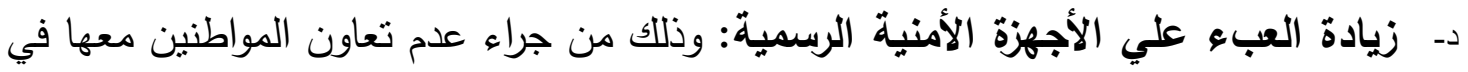

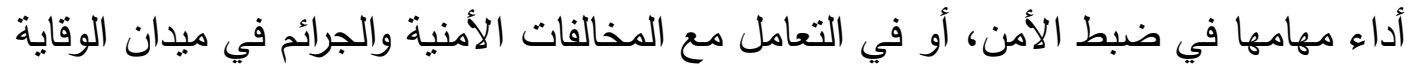

$$
\text { أو في ميدان المكافحة. }
$$

ه- بروز تصرفات غير مسؤولة أو مخلة بالأمن من الأفراد: نتيجة لقصور وعيهم الأمني وعدم

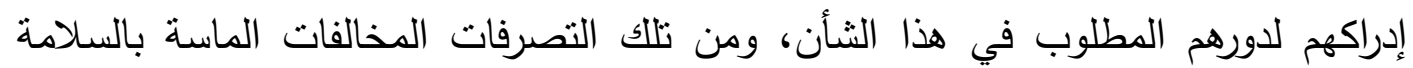
العامة في المجال المروري، أو مخالفة قواعد السلامة في المباني والمرافق والمنشآت

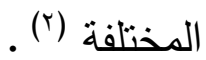
و- أضرار إقتصادية تمس الدولة والأفراد: علي حد سواء، لأن الخلل الأمني وانتشار الجرائم يؤدي إلي خراب المرافق والمنشآت العامة والممنلكات الخاصة. ز- الخسائر في الأرواح البشرية التي تذهب ضحية الجرائم علي الأبدان أو ما دون الأبدان.

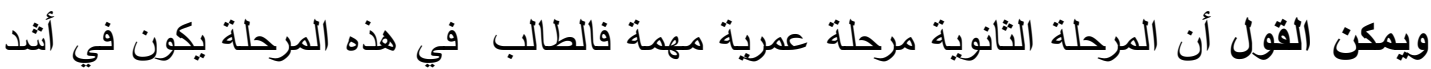
حالاته العاطفية، سريع الثأثر بما يجري حوله في المجتمع من تغيرات في جوانب الحياة المختلفة.

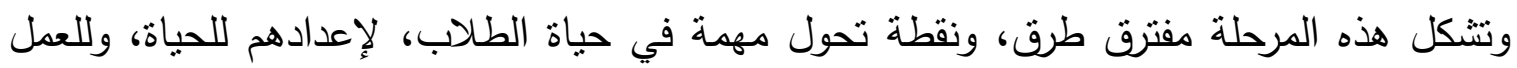

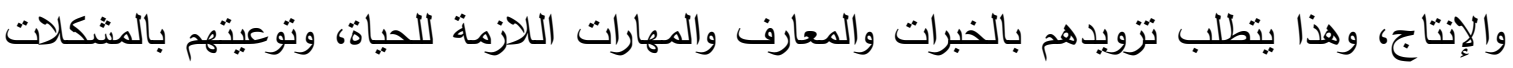

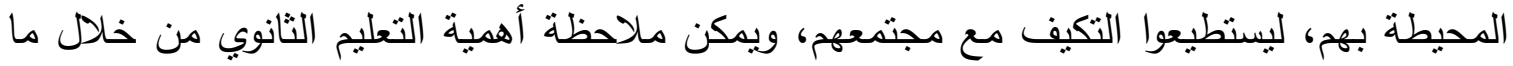

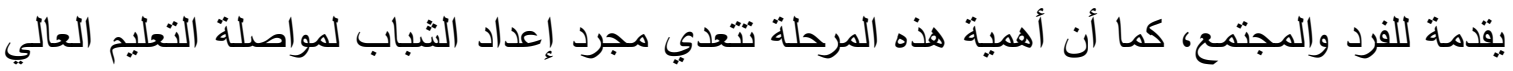

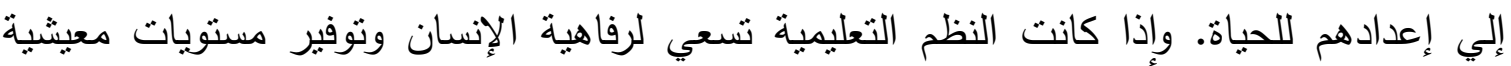

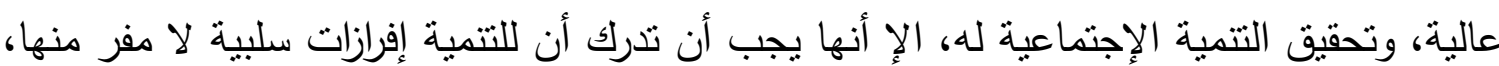
وبخاصة التتمية التي لا يدخل العنصر الأمني ضمن مخططاتها.

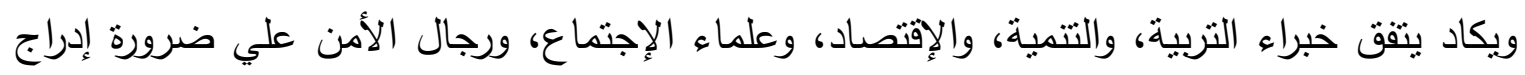
خطط أمنية ضمن مخططات التربية والتعليم ، للنقليل من حدة الإختال الأمني والتخفيف من أثاء الثاره

(1) (حسن شحاته،، المنهج الإسلامي للأمن والتتمية، خواطر إسلامية، القاهرة، جامعة الأزهر. شوقار ، جادي،

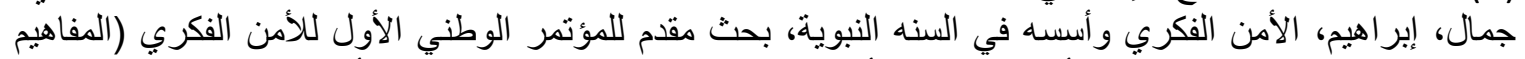

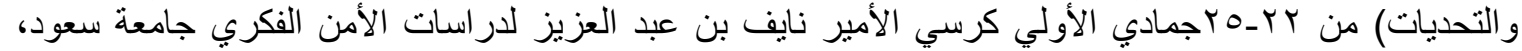

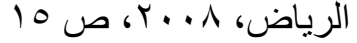

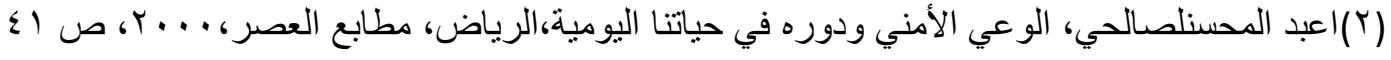


الضارة (')، ومن هنا أصبح المراهق يعيش في حيرة من أمره نتيجة التضارب بين تلك الافكار

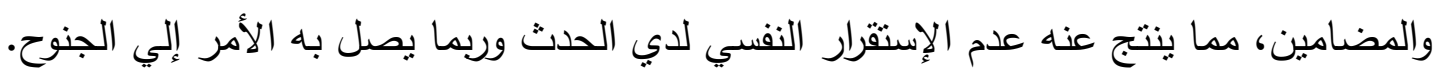
المحور الثاني: دور مؤسسات التعليم الثانوي في تحقيق التربية الامنية:أولاً: مبررات تحقيق التربية الأمنية في المرحلة الثانوية:

تجدر الإثشارة إلى أن طبيعة المرحلة الثانوية وما يتميز به طلابها من سمات وخصائص، والتغيرات الجذرية التي يشهدها العالم في ثورة العلم والتكنولوجيا قد أثنت على كافة نواحي الحياة ومنها

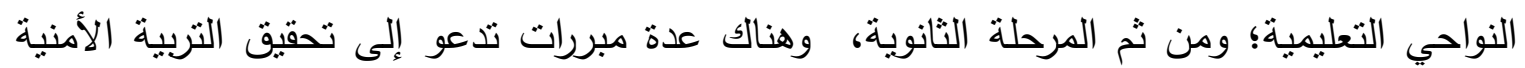
ويمكن سرد أهمها على النحو التالي (r) :. أ- التأثبر السلبي للإعلام وتقنية المعلومات والذي تسبب ضعف لهف دور الأسرة في إتخاذ التدابير التربوية والخلقية نحوها، والتأثير السلبي لبعض وسعائي التبات التربية غير الرسمية كجماعة الأقران والتي تعصف بما تأسس في التربية الأسرية وما يحتاجه ذللك من جهود نربوية وقائية وعلاجية من المدرسة.

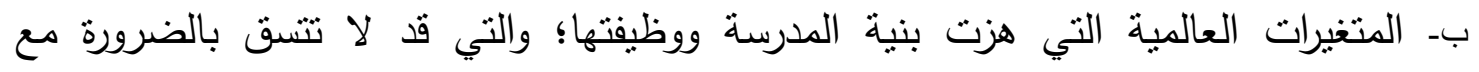
التوجهات الأخلاقية الحاكمة لسلوكيات المجتمع المدرسي المستمدة من الخصوصية التقافية. ج- تراجع الإمتيازات التربوية للمدرسة أمام ضغوط المؤسسات غير النظامية والنظامية كوسائل الإعلام مع تتامي ثقافة العنف في المجتمع، وانتشار الجريمة، وظاهرة النطرف والإرهاب،

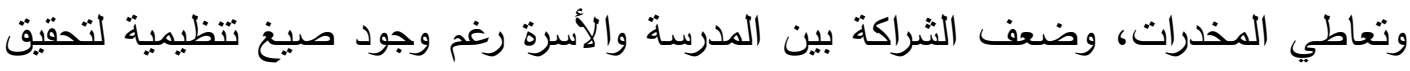
تلك الثراكة وذلك التعاون مثل مجالس الآباء والمعلمين مما ضعف فاعليتها كتظيمات داعمة لوظيفة الضبط الإجتماعي داخل المدرسة.

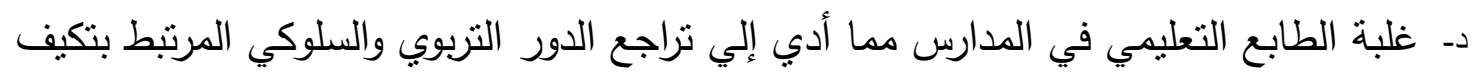

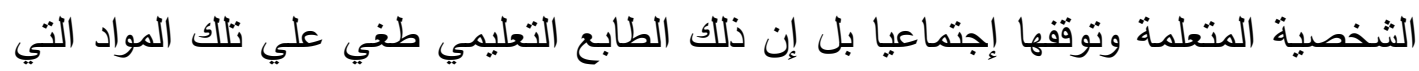
تصب في الجان الإجتماعي والسلوكي للطالب كمواد التربية الدينية والوطنية. هـ وجود العديد من المشكلات التي يجدها الطالب في المرحلة الثانوية ومنها: المشكلات

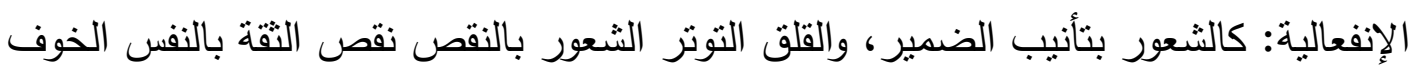

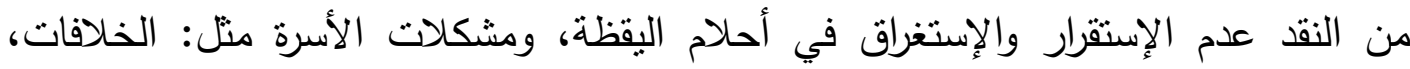
الإنفصال، الطلاق بين الوالدين، العقاب بالضرب وغيره، مناورة الوالدين والرد عليه،، معاملته

(')سليم الهذلي، درجة إسهام الإدارة المدرسية في تحقيق أهداف الأمن الفكري لدي طلاب المرحلة الثانوية بمدينة مكة المكرمة من وجهة

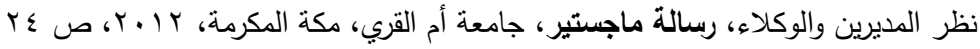

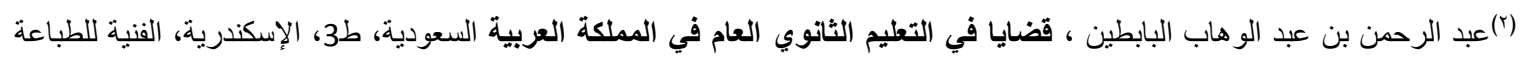

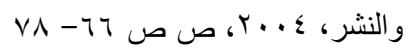


كطفل في الأسرة، وشعوره بأنه عبء علي الوالدين.، ومشكلات الددرسة مثل: صعوبة تركيز

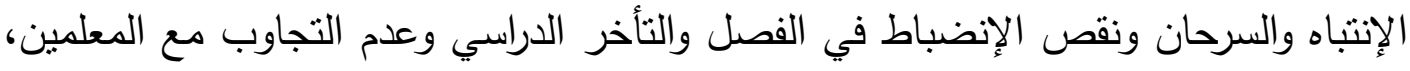
والمشكلات الإجتماعية منل: عدم القدرة علي التماسك في المواقف الإجتماعية، والخوف من النيان ارتكاب الأخطاء الإجتماعية الخوف من مقابلة الناس قلة الأصدقاء وعدم وجود من يناقش

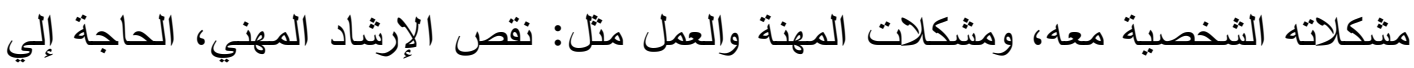
المساعدة في معرفة الفرص المناحه في المجالات المختلفة الحاجة إلي المساعدة في إختيار

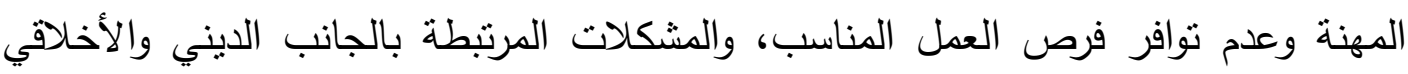
كالحاجة إلي الإرشاد الديني، وعدم إقامة البعض للشعائر الدينية وعدم إحترام القيم الأخلاقية

$$
\text { ومحاولة التغلب علي العادات السيئة. }
$$

وـ التراجع التدريجي لدور الأسرة في الضبط الإجتماعي نظراً لعدد من الأسباب كالتفكك الأسري

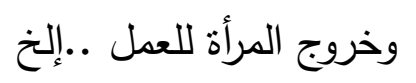

ومما سبق يتضح أن هناك مبررات كثثرة أمام المدرسة الثانوية نظرًا لحساسية هذه المرحلة

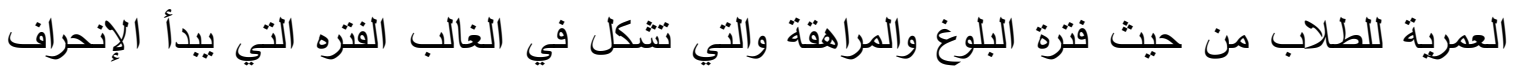
منها، الأمر الذي يتطلب إصدار التشريعات والقوانين التي تحظر العنف الددرسي، وتوفير العديد من في فئن برامج الحماية وبرامج ضد الجريمة، وتقديم خدمات لمساعدة الأسرة علي تقليل العنف. ثانيًا: ركائز التربية الأمنية في المرحلة الثانوية:

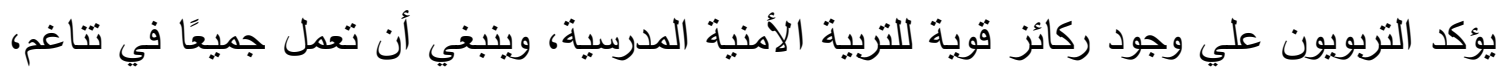

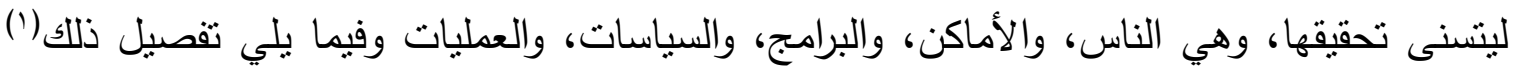

:(purkey, 1999)

أـ الناس: ينبغي أن يعمل المعلمون والعاملون في الددرسة كأسرة واحدة لأن الأنشطة المدرسية

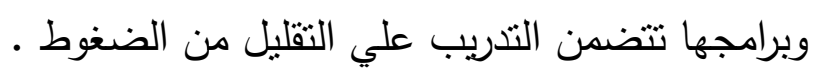

بـ الأماكن: ينبغي الإهتمام بالبيئة المادية للمدرسة، بما فيها الإضاءة الجيدة، والمباني، والغرف المباف

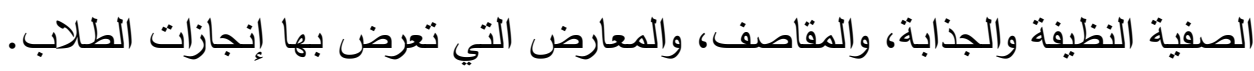

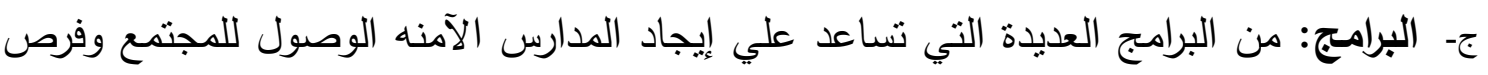

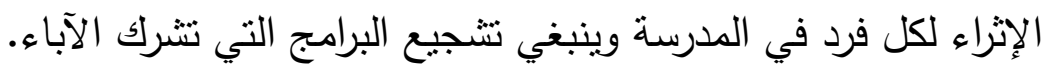

(1)Purkey, w ,creating safe schools through Invitational Education ,ERIC Identifi er ;ED ะr०१ะч. Pp.197-198. 
دـ السياسات: ويمنل ذللك في الخضوع، وتتظيم الفصول، والإنتقال، والنظام، وسياسات آخري

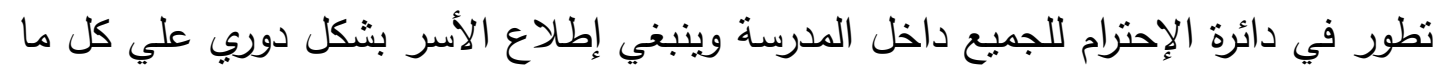
يهمهم عن أبنائهم. هـ العمليات:العملية هي الطريقة التي بها تؤدي بها الأعمال داخل المدرسة، وينبغي أن تصمم

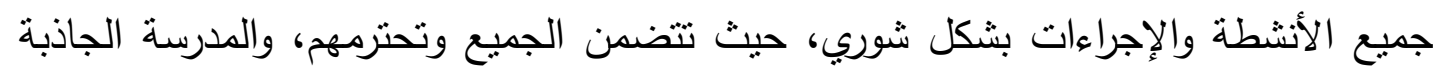
هي التي ترحب بكل الأفكار والإقتراحات ونقبلها بمرونه. و- النقافة المدرسية: هو وجود ثقافة مدرسية تتجع علي الإنضباط وتسعي لتحقيقه، فنقافة

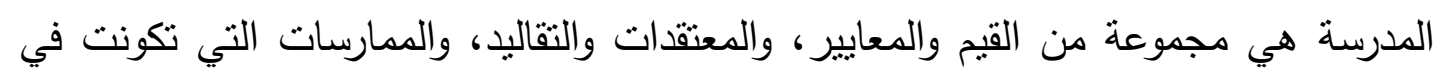

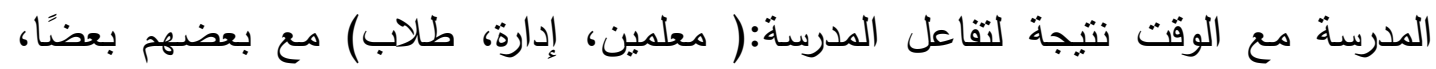

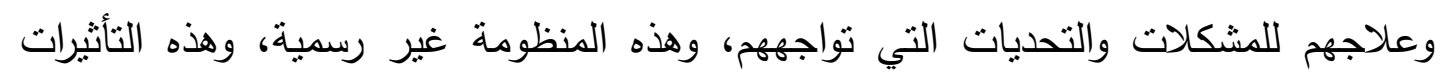

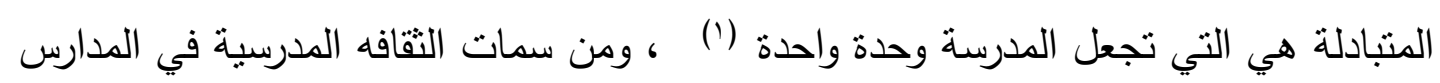

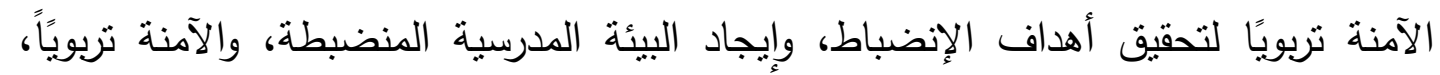
توفير بيئة تعليمية مشجعة للتعلم والإنضباط.

إجراعات الدراسة الميدانية ونتائجها

لتحقيق أهداف الدراسة قامت الباحثة ببناء بإجراء الدراسة الميدانية من خلال أداة الدراسة:

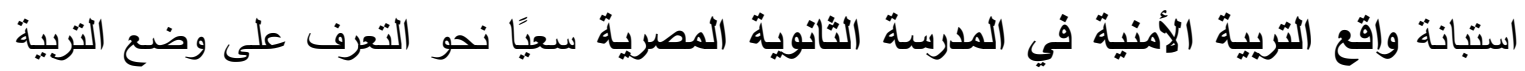

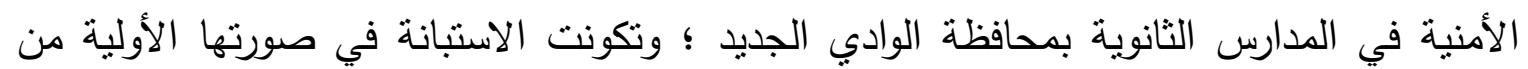
جزأين هما:الجزء الأول: البيانات الثخصية الجزء الثاني:- واقع التربية الامنية في مؤسسات التعليم الثانوي. أولاً: مرحلة التأكد من صدق الاستبانة: فقد تم مراعاة صدق الاستبانة من جانبين:1- أن اختبار المحاور والعبارات تم في ضوء أدبيات الدراسة والدراسات والبحوث السابقة المتصلة العولمة الثقافية ودور المعلم في مواجهنها. r- تم عرض الاستبانه على خبراء وأعضاء هيئة تدريس في الجامعات المختلفة وعددهم (19)

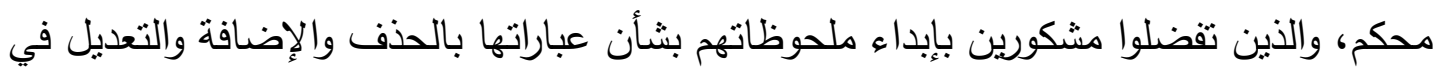

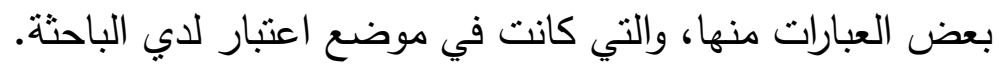


ثانيًا: صدق وثبات الاستبانة:

تم تطبيق الاستبانة علي (·r) معلما كعينة استطلاعية وذللك للتأكد من ثبات وصدق فقراتها

كالتالي: - n

صدق الاتساق الاخلي:Internal Validity : وهو مدى اتساق كل عبارة من عبارات الاستبانة

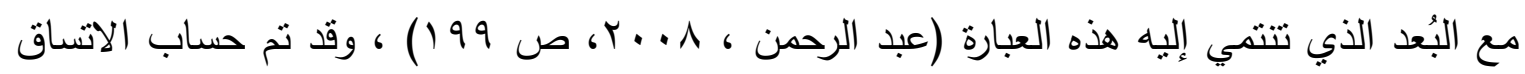

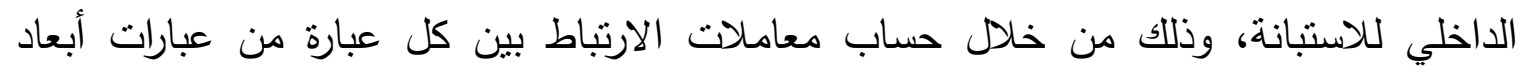

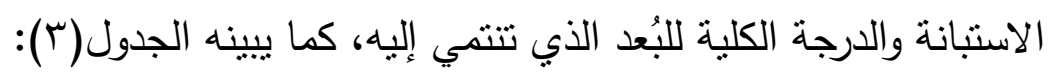

جدول(r)

قيم معامل الارتباط بين كل عبارة من عبارات البُعد مع الدرجة الكلية للبُعد.

\begin{tabular}{|c|c|c|c|c|c|c|c|c|c|c|}
\hline 1. & 9 & $\Lambda$ & V & 9 & o & $\varepsilon$ & $r$ & $r$ & 1 & /العبارا \\
\hline $\begin{array}{r}\cdot, V \Psi \\
*\end{array}$ & $\begin{array}{r}\cdot, \wedge r \\
*\end{array}$ & $\begin{array}{r}{ }^{*}, \wedge \wedge \\
*\end{array}$ & $\begin{array}{r}\cdot, \wedge r \\
*\end{array}$ & $*_{,}, \vee q$ & 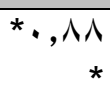 & $\begin{array}{r}* * \\
\cdot, 91\end{array}$ & $*_{,}^{*}, \mathrm{~V}$ & $*_{\bullet}^{*}, \mathrm{v}$, & $*_{,}, \vee q$ & الاول \\
\hline & & & $\begin{array}{r}\cdot, \wedge r \\
*\end{array}$ & $*_{0}, V$ & ${ }^{*}, v r$ & $*_{,}, \vee q$ & 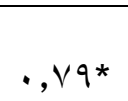 & $\begin{array}{r}* * \\
., 9 \\
., 9\end{array}$ & ., ২৭* & الثاني \\
\hline & & ${ }^{*} \cdot, \Lambda r$ & $\begin{array}{r}\cdot, \times 4 \\
*\end{array}$ & $\begin{array}{r}{ }^{*}, \wedge \wedge \\
*\end{array}$ & ${ }^{*} \cdot, T V$ & $\cdot, v \cdot *$ & $\begin{array}{r}{ }^{*}, \wedge \wedge \\
*\end{array}$ & ${ }^{*} \cdot, \vee \vee q$ & ${ }^{*},, v \cdot$ & الثالث \\
\hline & & $*_{*,, \vee q}$ & , ${ }^{*}{ }^{*}$ & $\begin{array}{r}*, \text {, } 0 \\
*\end{array}$ & $*_{,}, \vee \vee$ & $*_{,}, \vee q$ & $\begin{array}{r}*_{*}, 91 \\
*\end{array}$ & $*_{v}, \gamma$. & ${ }^{*_{*}, 9 \varepsilon}$ & الرابع \\
\hline
\end{tabular}

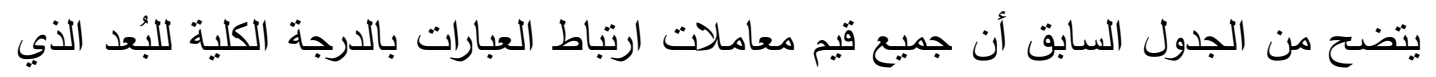
تتنمي إليه دالة إحصائياً عند مستوى( (.,.)، ويحقق هذا درجة مرتفعة من الاتساق الداخلي للعبارات.

د-r. الصدق البنائي:Structure Validity: للتحقق من الصدق البنائي بحساب معاملات الارتباط بين درجة كل بُعد من أبعاد الاستبانة والدرجة الكلية لعبارات الاستبانة، كما يبينه

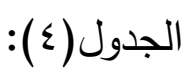

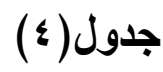

قيم معامل الارتباط بين كل بُعد من أبعاد الاستبانة مع الارجة الكلية لها.

\begin{tabular}{|c|c|c|c|c|}
\hline الرابع & الثالث & الثانى & الاول & البعد \\
\hline$* *, \wedge\rceil$ & $*,, \vee \wedge$ & $* *$ & $*,, \vee q$ & معامل الارتباط \\
\hline
\end{tabular}

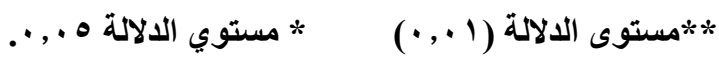


يتضح من الجدول السابق أن جميع قيم معاملات بيرسون للارتباط لجميع الأبعاد تراوحت ما

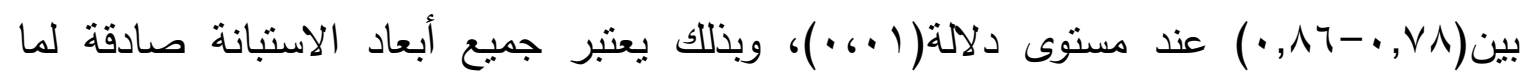
وضعت لقياسه.

هـ- ثبات الاستبانة Reliability: أي مدى انساق نتائج الاستبانة، فالمقياس الثابت هو الذي

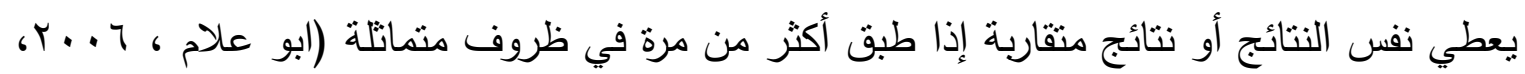

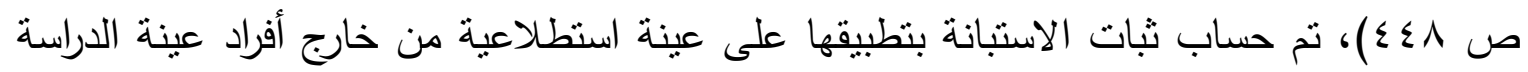

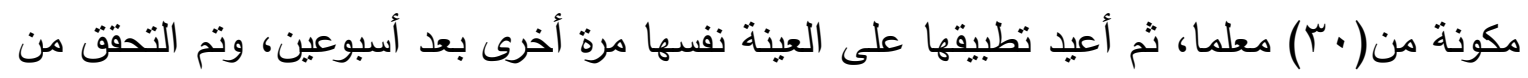

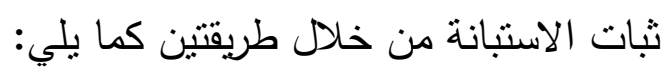
هـ- 1 ـ معامل ألفا كرونباخ Cronbach's Alpha Coefficient: تم حساب معاب معامل الاتساق الداخلي ألفا كرونباخ لكل بُعد من أبعادها وللاستبانة ككل، كما يبينه الجدول(ه): جدول (0) معامل الثبات(الفا كرونباخ) لأبعاد الاستبانة.

\begin{tabular}{|c|c|c|c|}
\hline معامل ألفا & البُعد & معامل ألفا & البُعد \\
\hline$\cdot$, , NT & 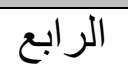 & $\cdot, \wedge$. & الأول \\
\hline$\cdot, \mathrm{\vee} \wedge$ & الثاالث & $\cdot, \wedge$. & الثاني \\
\hline \multicolumn{3}{|c|}{$\cdot, \mathrm{VA}$} & معامل الثبات الكلى \\
\hline
\end{tabular}

يتضح من الجدول السابق أنه تراوحت قيم معامل الثبات (معامل ألفا كرونباخ) لجميع الأبعاد

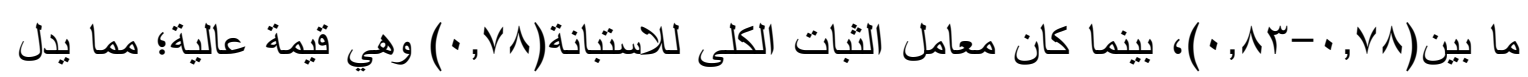

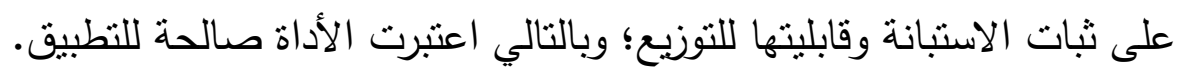
هـ - معامل الإرتباط بين التطبيقين حيث نم تطبيق الاستبانة علي عدد (•r) معلم من غير عينة الدراسة ثم اعيد نطبيقها بعد مرور

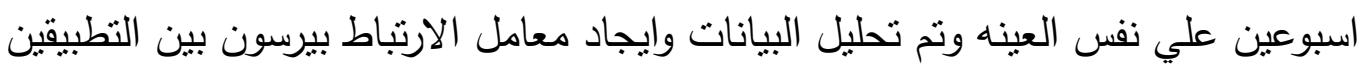
جدول(؟) معامل الارتباط بين التطبيقين.

\begin{tabular}{|c|c|c|c|}
\hline الارتباط & البُعد & الارتباط & البُعد \\
\hline$\cdot$, Vo & الثالث & $\cdot, \wedge \mathrm{V}$ & الأول \\
\hline$\cdot, \wedge \varepsilon$ & الر ابع & $\cdot, 9 \leqslant$ & الثاني \\
\hline \multicolumn{3}{|c|}{$\cdot, \wedge \mu$} & معامل الثبات الكلي \\
\hline
\end{tabular}

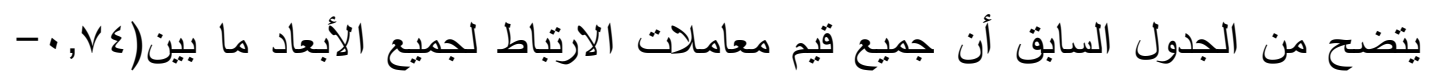

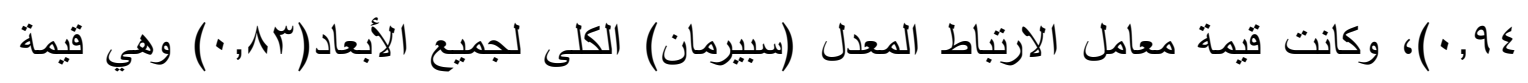
عالية؛ مما يدل على ثبات الاستبانة. 
ثانيًا:عينة الدراسة وإجراءات اختيارها:

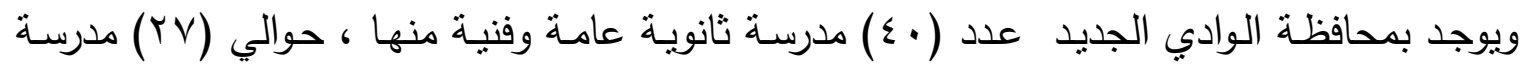
ثنانوية عامة ، (T () مدرسة للتعليم الفني موزعة علي إدارات (الخارجة - الداخلة- بلاط- الفرافرة -

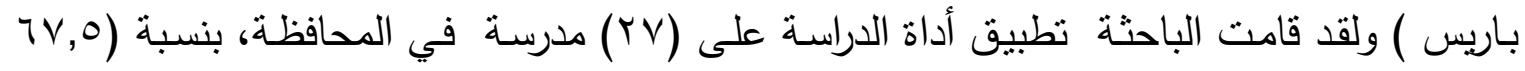
\% بالنسبة لإجمالي عدد المدارس). جدول ( ) يوضح المدارس الثانوية التي تم التطبيق عليها.

\section{جدول (1)}

المدارس الثانوية التي تم التطبيق عليها

\begin{tabular}{|c|c|c|c|}
\hline العدد & أسماء المدارس الثانوية & المدينة & م \\
\hline Ir & 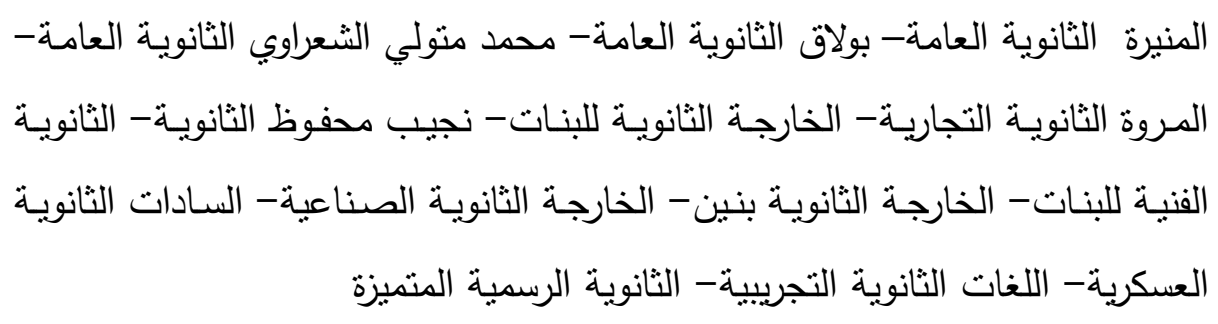 & 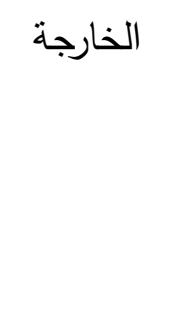 & -1 \\
\hline$\varepsilon$ & القلمون الثانويـة- الثــيد أحمد المنسي الثانويـة- العسكرية- موط الثانويـة الزراعية- & الداخلة & $-Y$ \\
\hline 7 & 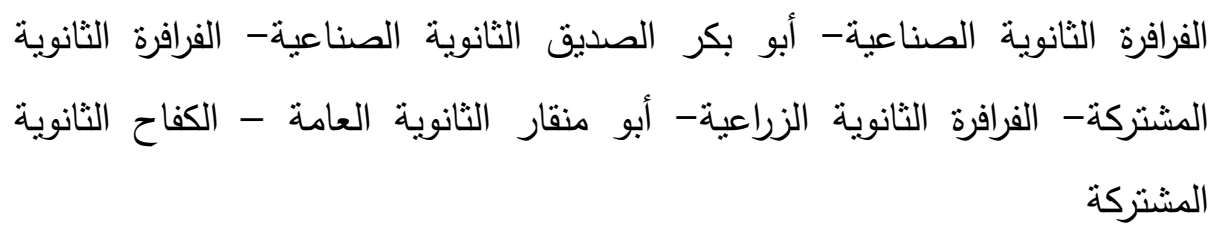 & 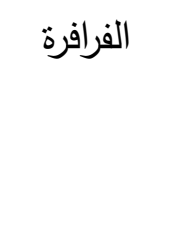 & r \\
\hline r & بلاط الثانوية العامة- تتيدة الثانوية العامة- بلاط الثانوية الزراعية & 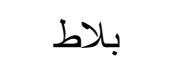 & $\varepsilon$ \\
\hline r & باريس الثانوية العامة- باريس الثانوية الزراعية & 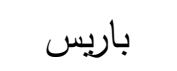 & $\circ$ \\
\hline & 27 & 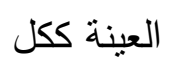 & \\
\hline
\end{tabular}

ويتضح من الجدول السابق نتوع المدارس التي نم إجراء الدراسة الميدانية فيها بهدف الحصول علي أراء موثوقة وتعبر عن مدي واسع لمجتمع الدراسة. وقد تمنلت عينة الدراسة في جميع معلمي ومعلمات المدارس الثانوية بمحافظة الوادي لكثرة

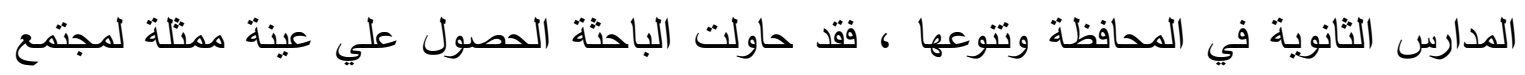
الدراسة ، جدول (r) يوضح مواصفات عينة الدراسة. 
جدول(؟) خصائص عينة الداسة.

\begin{tabular}{|c|c|c|c|c|c|c|}
\hline 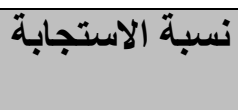 & عدد الاستمارات & | نسبة التمثيل & الدراسةة & مالدراسة & الفئات المستهدفة & b \\
\hline$\% 1 \cdots$ & 104 & $\% 1\{$ & 104 & 1.0 & معلمي المدارس الثانوية العامة.(') & 1 \\
\hline$\% \wedge \vee, Y \vee$ & $\leqslant 1$ & $\%$ \%r & 00 & \&VY & معلمي المدارس الثانوية الفنية.(r) & $r$ \\
\hline$\% \wedge \vee, Y Y$ & « & $\% 17$ & $\varepsilon V$ & r^^ & معلمي المدارس الثنانوية الزراعية.(() & $r$ \\
\hline$\%^{\wedge \varepsilon, \varepsilon \varepsilon}$ & $r \Lambda$ & $\% \leqslant r$ & \&0 & $1 . \varepsilon$ & معلمي المدارس الثانوية التجارية.(؟) & $\varepsilon$ \\
\hline \%qr,r & $r \wedge$. & $\% 17$ & r.. & $191 \varepsilon$ & الإجمالي & \\
\hline
\end{tabular}

يلاحظ من الجدول السابق تتوع النسب الممثلة لعينة الدراسة بالنسبة لمجتمع الدراسة ككل ، حيث

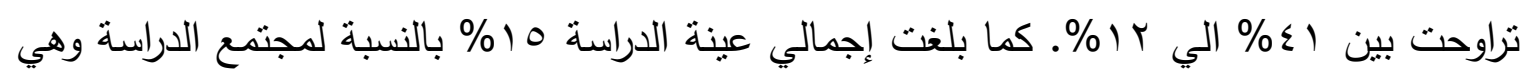

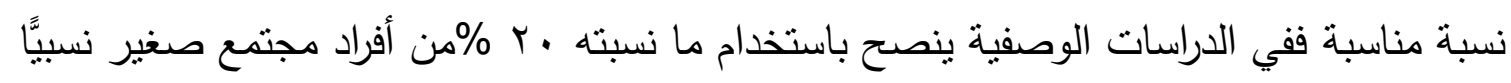

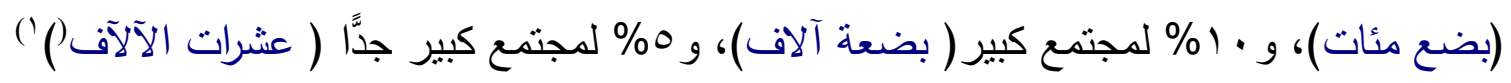

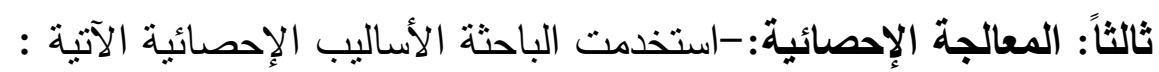

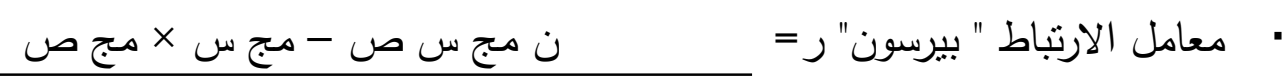

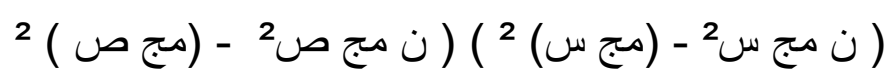
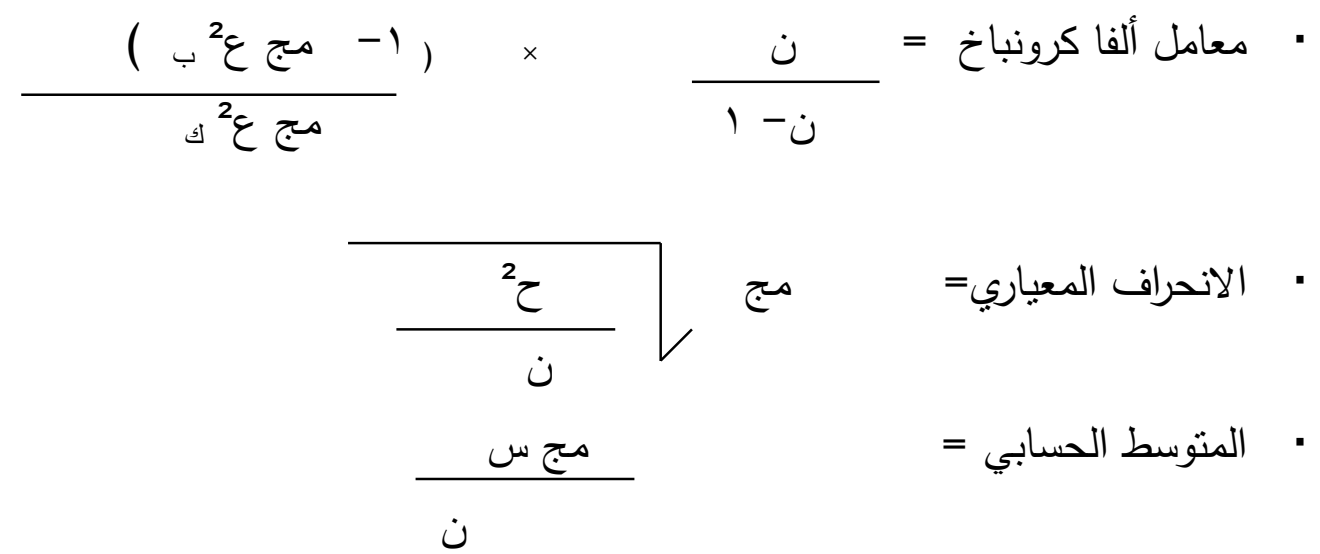

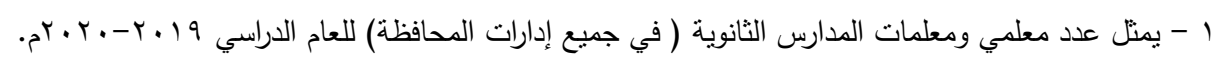

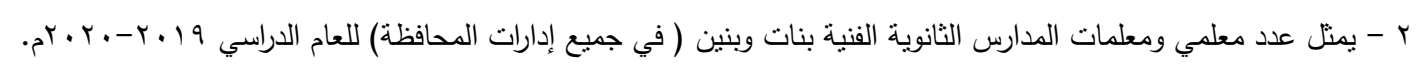

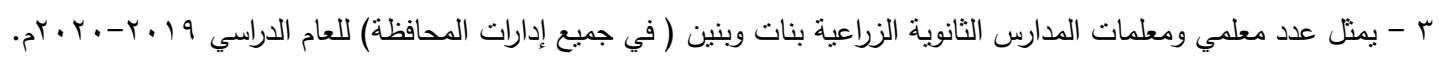

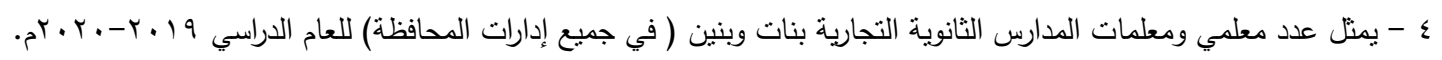

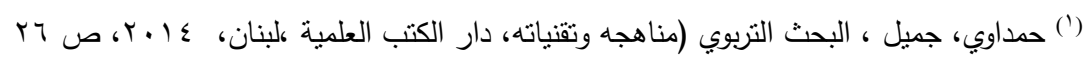




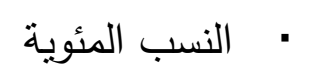

• • معامل الصدق الذاتي = جذر معامل الثبات

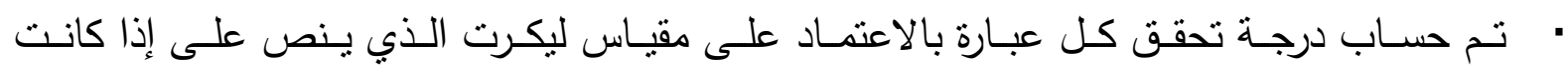

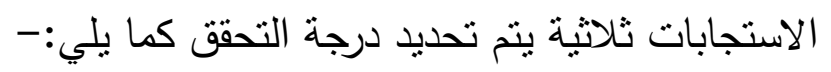

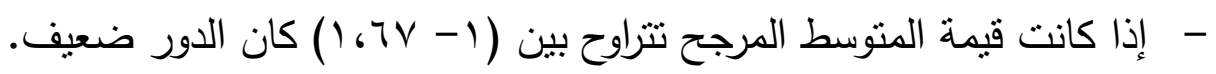

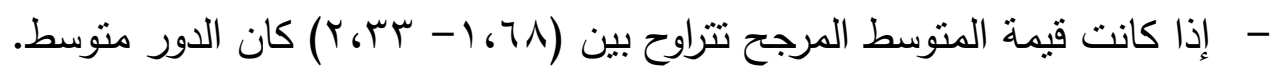

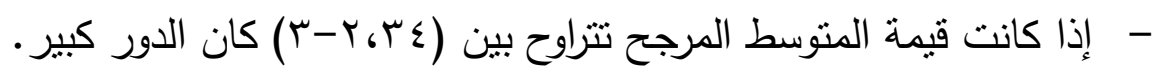
نتائج الاراسة الميدانية وتفسيرها فيما يلي عرض للنتائج التي تم التوصل إليها من خلال الإجراءات السابق ذكرها:-

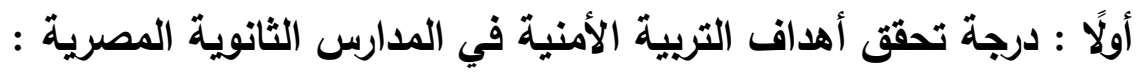

وللوصول إلى وجهة نظر أفراد العينة من معلمي المدارس الثانوية (العامة والزراعية والصناعية

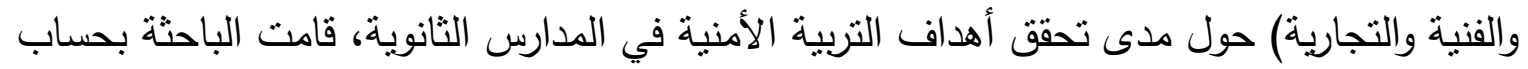

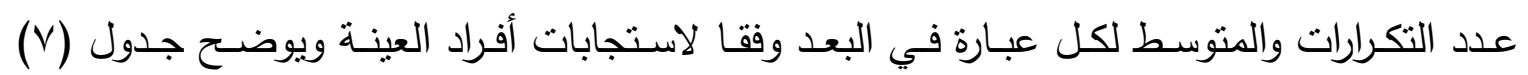

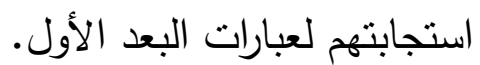


جدول (v)

وجهة نظر أفراد العينة حول تحقق اهداف التربية الأمنية في الدارس الثانوية.

\begin{tabular}{|c|c|c|c|c|c|c|c|}
\hline \multirow[b]{2}{*}{ الترتيب } & \multirow[b]{2}{*}{ الاتجاه } & \multirow[b]{2}{*}{ المتوسط } & \multicolumn{3}{|c|}{ النسبة } & \multirow[b]{2}{*}{ 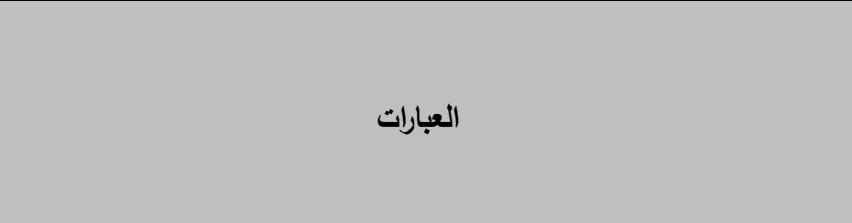 } & \multirow[b]{2}{*}{ s } \\
\hline & & & غوافق & موافق & موافق & & \\
\hline 0 & 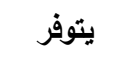 & r, VV & $7, \cdot \vee$ & 1. & $\wedge r, q r$ & توضح للطلاب أهمية الأمن والإستقرار والسلامة لبناء المجتمع وتطويره . & 1 \\
\hline$\checkmark$ & يتوفر & ץ, ૧. & $\cdot, 1$ & Ir,ov & $V ५, \varepsilon Y$ & توعي الطلاب بأخطار الجرائم والإنحرافات السلوكية واضرارها علي الفرد & $r$ \\
\hline$\wedge$ & يتوفر الي & r, r. & $\cdot, 1 r$ & $01, \vee \wedge$ & $r_{\uparrow, \cdot V}$ & تدرب الطلاب علي آليات الحماية والدفاع عن النفس من المجرمين & $r$ \\
\hline 7 & يتوفر & Y,V & $\cdot, \cdot V$ & $9, Y \wedge$ & $\Lambda r, O V$ & ترستخ شعار الأمن مسئولية الجميع & $\varepsilon$ \\
\hline 1 & يتوفر & $r, q q$ & - & $\cdot, v_{1}$ & $q ৭, r q$ & تغرس قيم وقيم الولاء والإنتماء وغيرها من القيم المجتمعية المرغوية. & o \\
\hline$\varepsilon$ & يتوفر & $r, \wedge \vee$ & $\cdot, \cdot \varepsilon$ & $\bullet, r \Delta$ & $91, \cdot v$ & تعزز دور الثرطة ورجالها في حماية الوطن وتقديم المساعدة للمحتاجين . & 1 \\
\hline$\wedge$ & يتوفر إلي & r, r. & $\cdot, \cdot 7$ & $10, v 1$ & $r \wedge, \diamond V$ & تلعم المشاركة المجتمعية بين المؤسسات التريوية والمؤسسات الأمنية. & 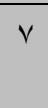 \\
\hline$r$ & 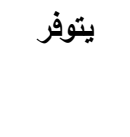 & r, १० & $\cdot, \cdot 1$ & r, $1 \leq$ & $৭ ५, \vee \wedge$ & تعرف الطلاب القضايا السياسية والأمنية الداخلية والخارجية وعلاقة الدولة & $\wedge$ \\
\hline$r$ & يتوفر & r, १० & $\cdot, \cdot 1$ & $1, \varepsilon r$ & $9 \vee, 1 \leq$ & تقلل العنف داخل المدرسة . & 9 \\
\hline r & 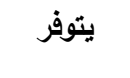 & r, १V & $\cdot, \cdot 1$ & $\cdot, v_{1}$ & $q \wedge, r \cdot$ & تسهم في التفوق الدراسي للطلاب من خلال توفير جو دراسي آمن مستقر . & 1. \\
\hline & & & Y, $\vee \varepsilon$ & & & 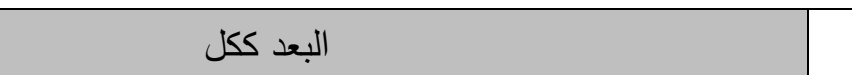 & \\
\hline
\end{tabular}

يتضح من الجدول السابق أن أفراد العينة ككل متفقون على أهداف التربية الأمنية محققة بدرجة

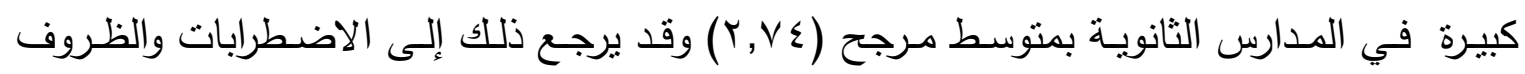

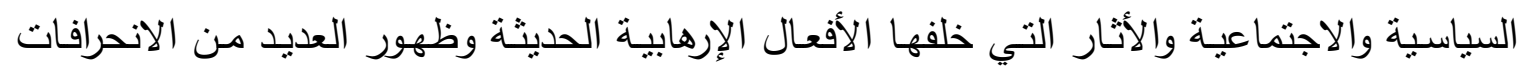
والاضطرابات السلوكية لدي الطلاب من تتمر وعنف مدرسي مما دفع التربويين وصناع القرار في الإني

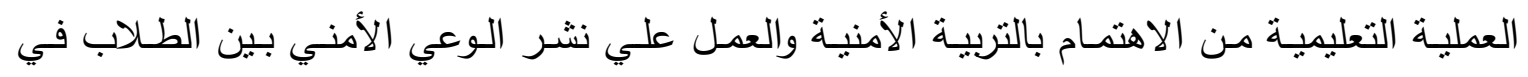


المدارس وتعزيز تقافتهم الأمنية من خلال توزيع نشرات تهدف في مضمونها إلي تحقيق أهداف التربية الأمنية داخل المدارس بالإضافة الي نشر فكرة المدارس العسكرية في المدارس الثانوية العامة والفنية ـ كما يتضح من الجدول السابق النتائج التالية:

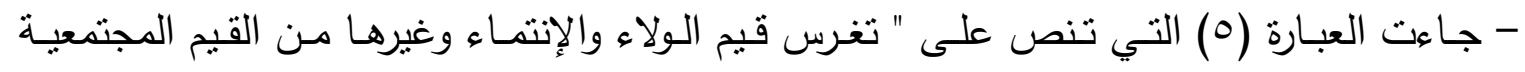

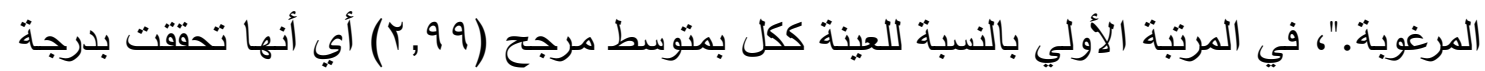

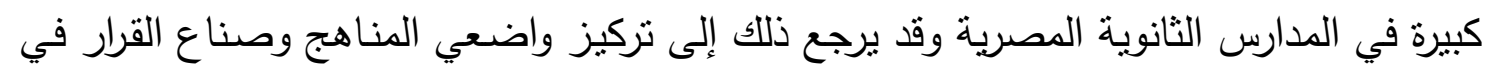

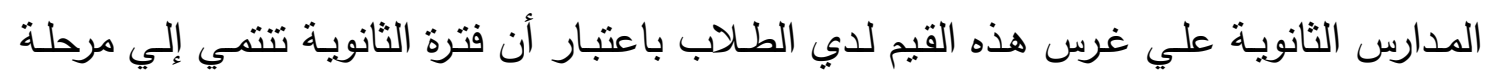

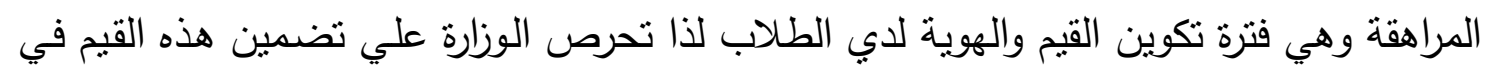

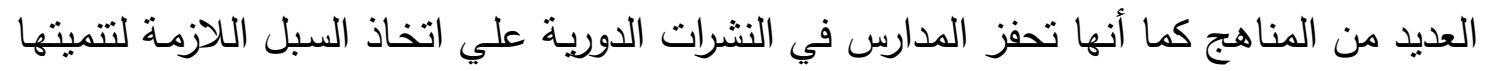

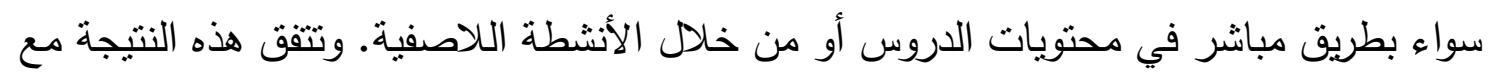

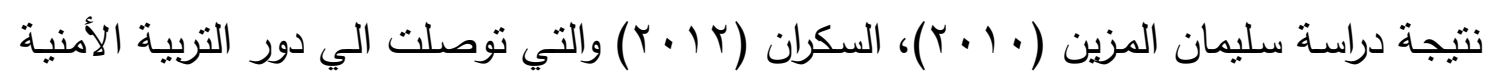

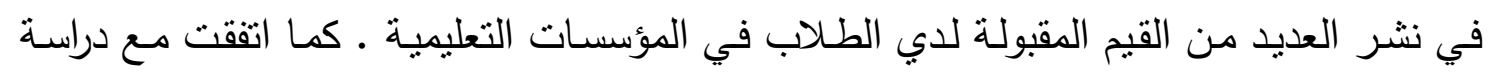
(2013) والتي توصلت إلي نجاح برنامج التربية الأمنية في غرس القيم المجتمعية

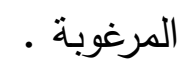

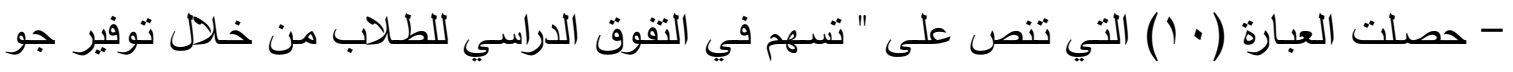

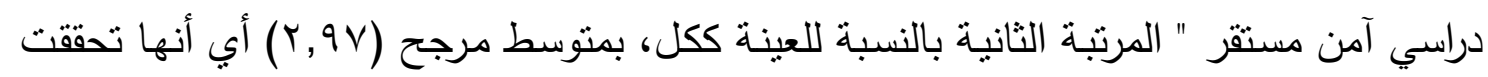

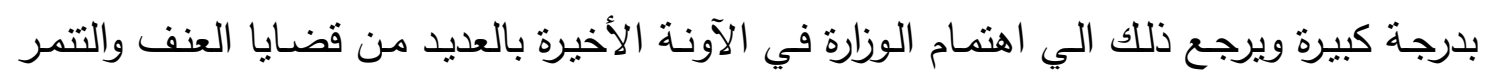

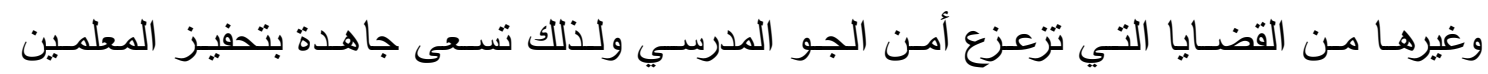

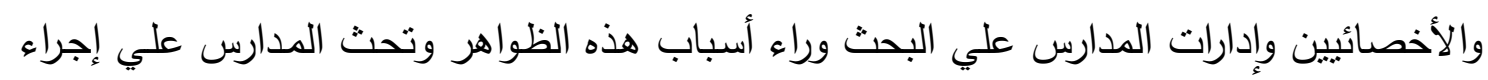

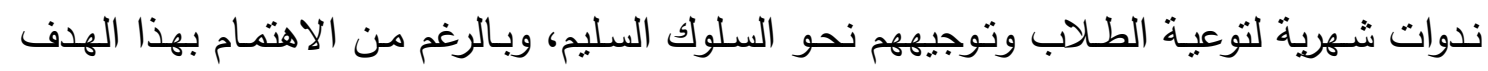

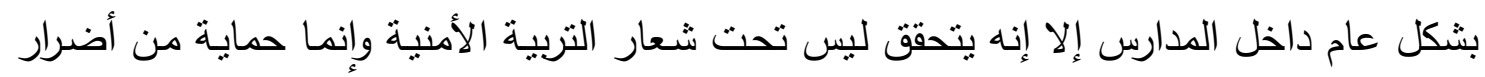

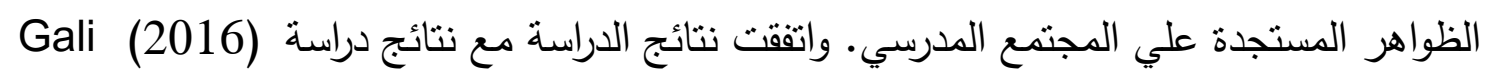

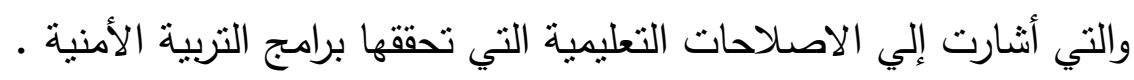

- حصـلت العبـارة (^) التـي تنص على " تعـرف الطـلاب القضـايا السياسـية والأمنيـة الداخليـة

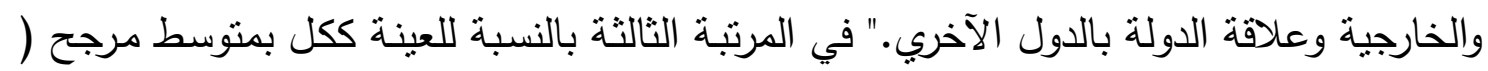

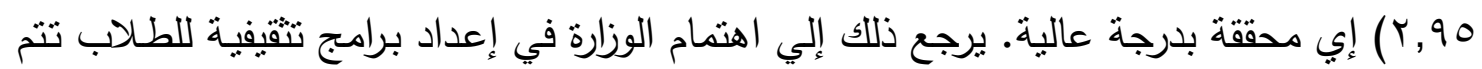

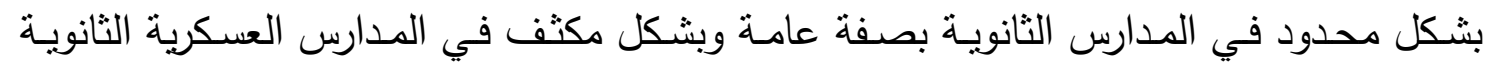
والفنية تهدف الي نوعية الطلاب بأهمية جمهورية مصر العربية ومكانتها بين الدول ـ واتفقت هذه 


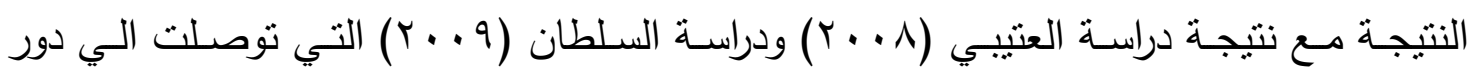
التربية الأمنية في نشر القضايا الأمنية .

- جاعت ايضـا العبارة (9) التي تنص على " تقلل العنف داخل المدرسـة "، في المرتبـة الثالثة

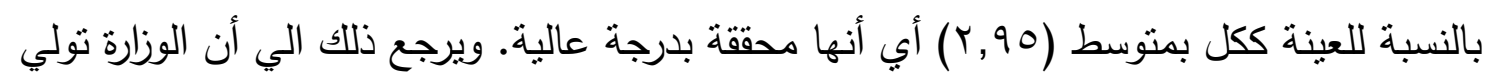

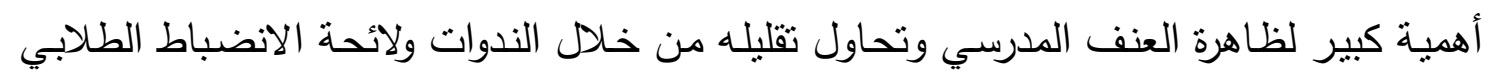

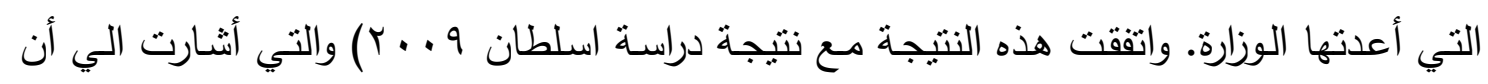

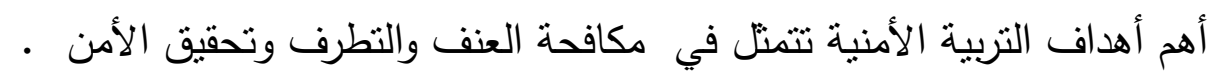

- جاءت العبارة (7) والتي تنص على " تعزيز دور الثشرطة ورجالها في حمايـة الوطن وتقديم

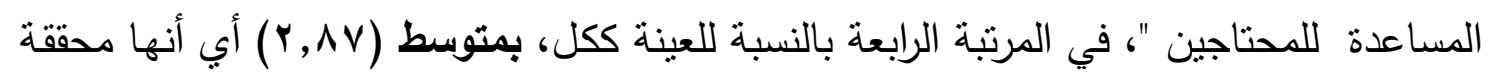

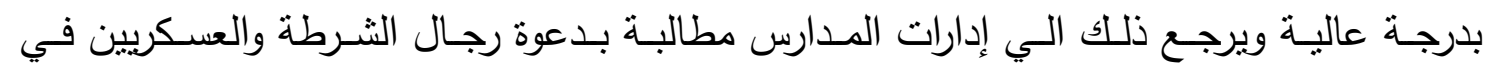
المناسبات الوطنية في المدارس لحضور الاحتفالات الوطنية وإلقاء كلمة للتوعية بدورهم في حماية

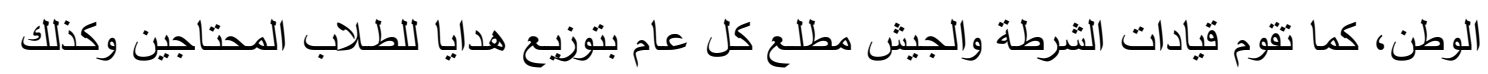

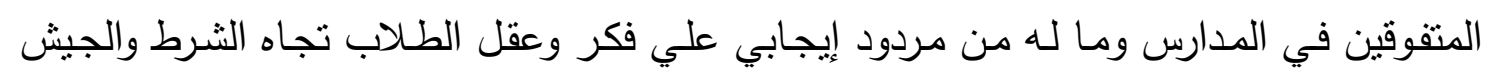
ورجالهم.

- حازت العبارة ( ) والتي تنص على " توضح للطلاب أهمية الأمن والإسنقرار والسـلامة لبناء

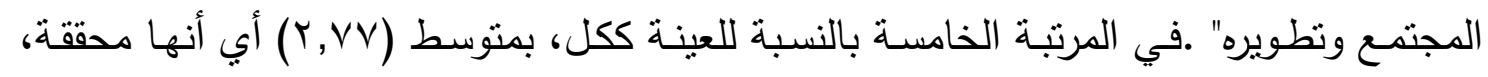

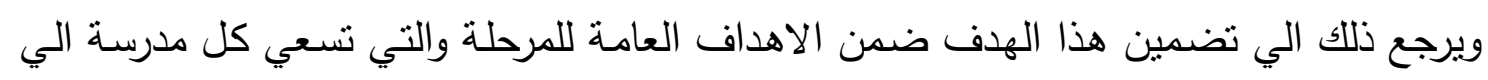

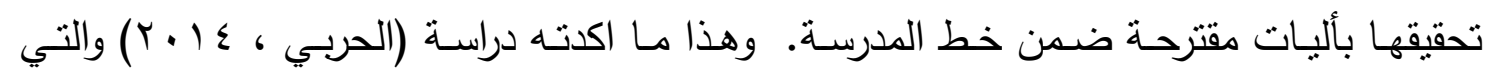

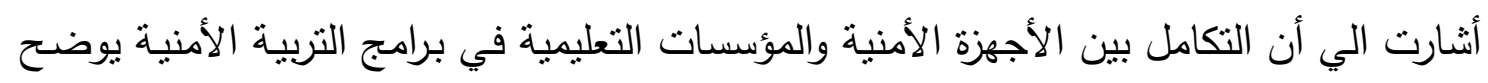

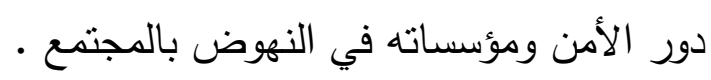

- جاءت العبارات (؟) التي تتص علي " ترسخ شعار الأمن مسئولية الجميع" في المرتبة السادسة

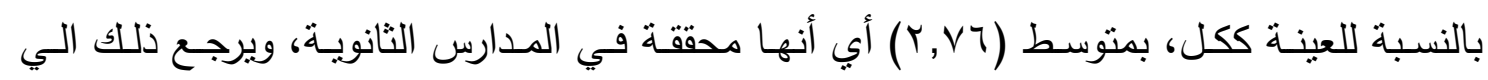

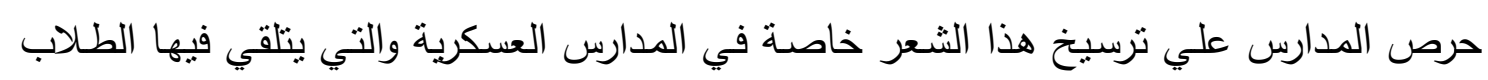

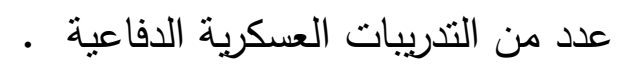
- حصلت العبارة (Y) التي تنص علي " توعي الطـلاب بأخطـار الجرائم والانحرافـات السلوكية

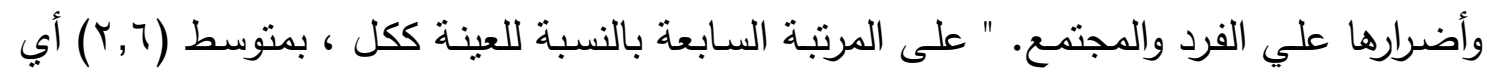

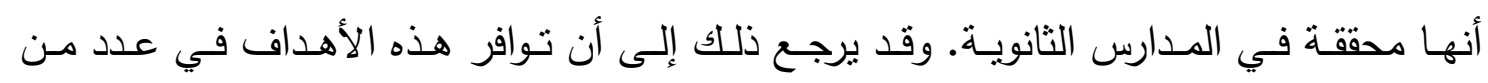

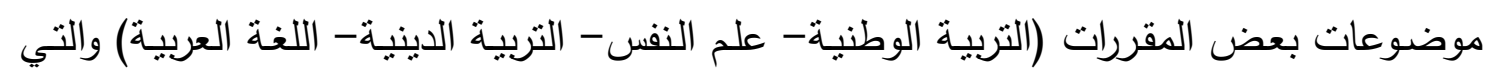


تسعى الي تبصير الطلاب بخطورة الجرائم علي الفرد والمجتمع. وهذا ما اكدته دراسة (السكران ،

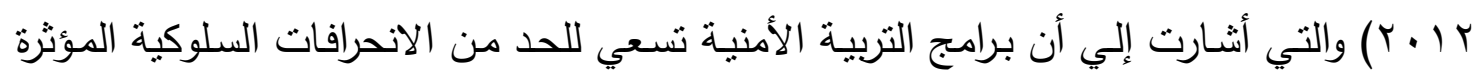

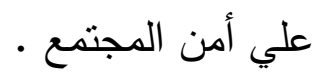
- حازت العبارة (r) والتي تتص علي " تدرب الطلاب علي آليات الحماية والدفاع عن النفس من

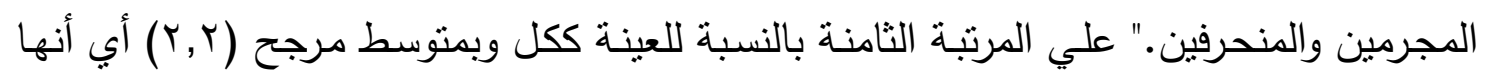

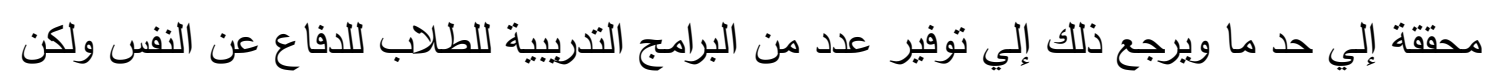

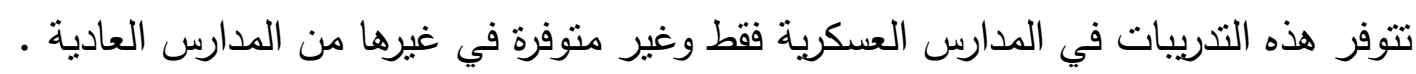
- كما حازت العبارة (V) والتي تنص علي " تدعم المشـاركة المجتمعيـة بين المؤسسـات التربويـة

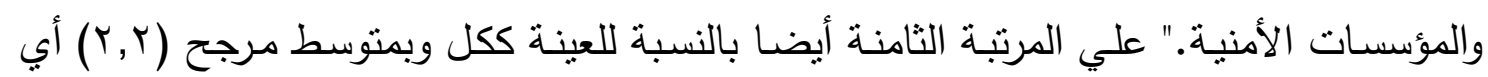

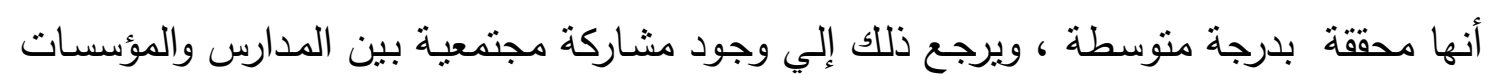
الأمنية ولكن ذلك غير متوفر في كل المدارس وإن وجد ينم في صورة مشـاركة في الاحتفالات

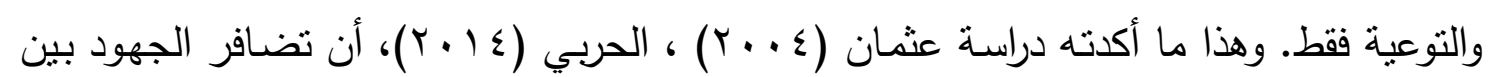
مؤسسات الأمن والمؤسسات التعليمية هي أهم أهداف التزبية الأمنية . ثانيا سياسات تحقيق التربية الأمنية في المدارس الثانوية المصرية . وللوصول إلى وجهة نظر أفراد العينة من معلمي المدارس الثانوية (العامة والزراعية والصناعية

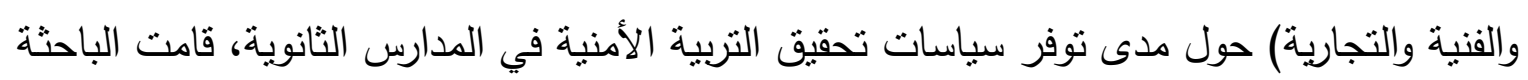

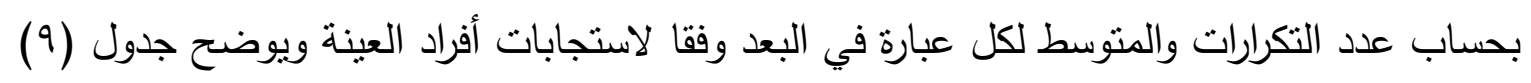
استجابتهم لعبارات البعد الثالث. 


\section{جدول (9) ج (9)}

وجهة نظر أفراد العينة حول توفر سياسات تحقيق التربية الأمنية في المدارس الثانوية.

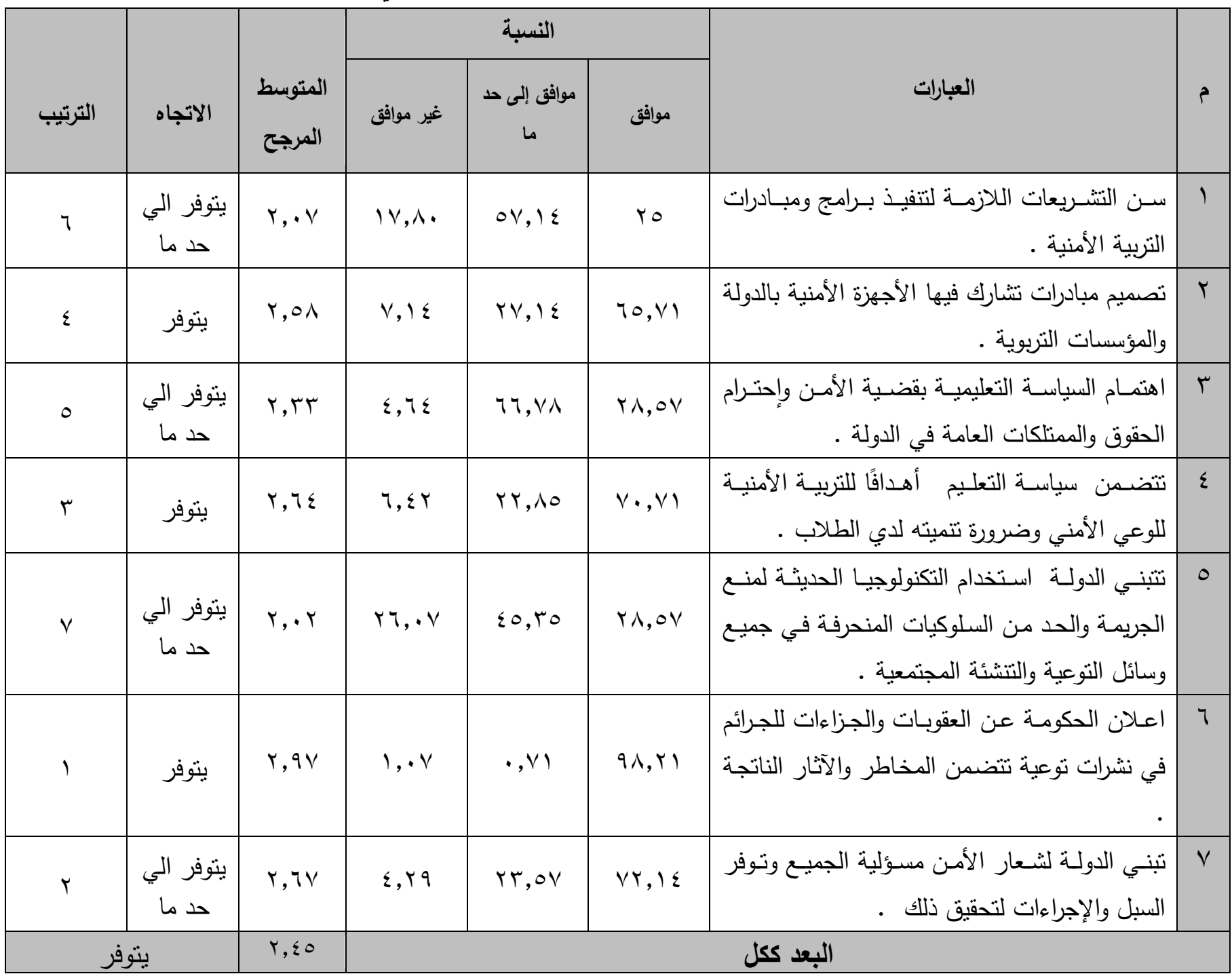

يتضح من الجدول السابق أن أفراد العينة ككل متفقون على أن سياسات تحقيق التربية الأمنية

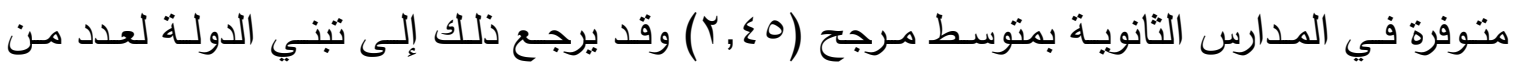

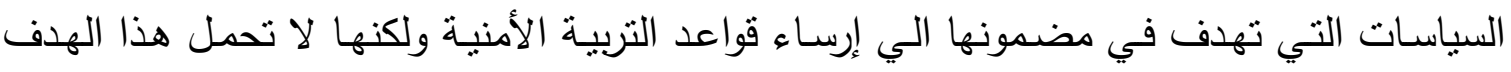
بشكل واضح بل قد يكون من أجل تحسين الجوانب السلوكية للطلاب وتطوير الجانب القيمي لديهم. كما يتضح من الجدول السابق النتائج النالية: - جاءت العبارة (7) والتي تنص علي " اعـلان الحكومـة عن العقوبات والجزاءات للجرائم في

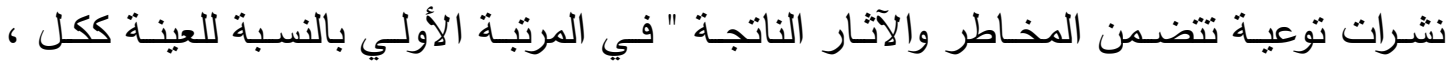

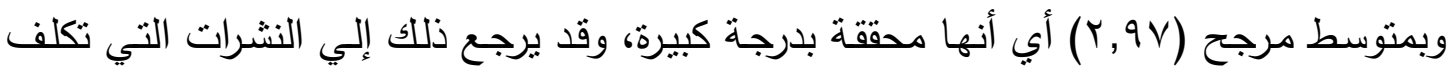


فيه الوزارة الأخصـئيين الاجتماعيين والنفسيين في المدارس وكذلك رواد الفصول في حصص الربادة من تعريف الطلاب بدواعي الأمن وعقوبات الجرائم وكذلك قواعد الانضباط السلوكي.

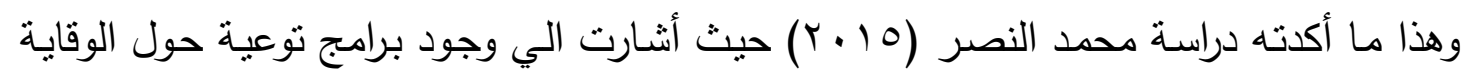
من الجريمـة توضـح كيف يمكن للتناميذ تحصين أنفسـهم من الجريمـة ومعرفة السبل الناجحة للوقاية منها - جاءت العبارة (V) والتي تنص علي " تبني الدولة لشعار الأمن مسؤلية الجميع وتوفر السبل والإجراءات لتحقيق ذلك " في المرتبة الثانية بالنسبة للعينة ككل ، وبمتوسط مرجح (Y,TV)، أي أنها محققة ، ويرجع ذلك الي اهتمام الدولة في الآونة الاخيرة بتوعية افراد المجتمع بقواعد الأمن والحماية وخاصة عقب ثورة Oب يناير والانفلات الأمني الذي تبعها، حيث سخرت الدولة وسـائل الاعـلام المختلفة لعرض بـرامج لتوعيـة الافراد ، امـا في المدارس الثانويـة فينت توجيـه نشرات للمدارس بعقد لقاءات مع مسئولي الامن بتوعية الطلاب باجراءات الامن الازمة وكذلك يتم يتم ممارسة أنشطة لاصفية منل المسرحيات والمبادرات التي توعي الطلاب بمسئولية الأفراد

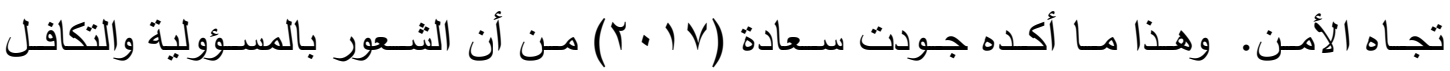
الاجتماعي والتعايش السلمي المشترك من أهم آليات تحقيق التربية الأمنية . - جاءت العبارة (ع) والتي تنص علي " تتضـن سياسـة التعليم أهدافًا للتربيـة الأمنيـة للوعي الأمني وضـرورة تتميته لدي الطـلاب" في المرتبـة الثالثة بالنسبة للعينـة ككل وبمتوسط مرجح

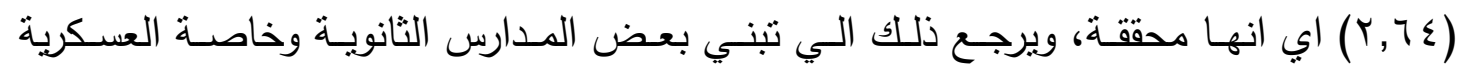
حصصا كنشاط لاصفي لتنمية الوعي الامني لدي الطلاب، بالاضافة الي توجيه ادارات التربوية المدارس لعقد ندوات مسع رجال الامن تهدف الي تتمية الوعي الامني لدي الطلاب مرة واحدة علي الاقل في عدد كبير من المدارس في المراكز المدنية الكبري. وهذا ما اكدته دراسـة محمد النصر (10 • ب) الي وجود جهود واضحة للوزارة في لتحقيق الأمن والسلامة - جاءت العبارة (Y) والتي تنص علي " تصـميم مبـادرات نثـارك فيهـا الأجهزة الأمنيـة بالدولـة والمؤسسات التربوية ." في المرتبة الرابعة بالنسبة للعينة ككل، بمتوسط مرجح (Y,ON) أي أنها محققة بدرجة كبيرة ، ويرجع ذلك إلي توجه عدد من المدارس الثانوية الي عمل مبادرات سواء داخل المدارس بمعاونة رجال الأمن والجيش لتصميم عدد من الأنشطة للتعريف برجال الأمن أو لورئه من خلا الزيارات الميدانية للمؤسسات العسكرية . - جاءت العبارة (r) والتي تنص علي " اهتمـام السياسـة التعليميـة بقضية الأمسن وإحترام الحقوق والممتلكات العامة في الدولة ." في المرتبة الخامسة بالنسبة للعينة ككل بمتوسط مرجح (T, Y, أي أنها محققة بدرجة متوسطة، وقد يرجع ذلك إلي تبني الدولة عدد من الأهداف التعليمية والقيم 
المنضمنة في المقررات الدراسية كاللغة العربية والتربية الوطنية ولكن بشكل بسيط وغير مكثف

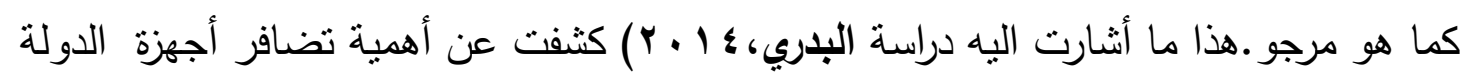

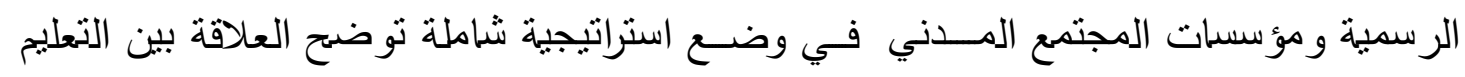

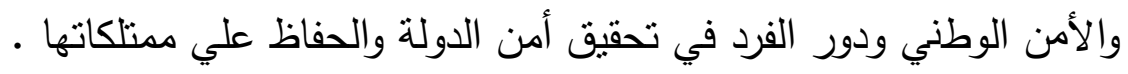
- - جاءت العبارة ( (1) والتي تتص علي " سن التشريعات اللازمة لتنفيذ برامج ومبادرات التربية

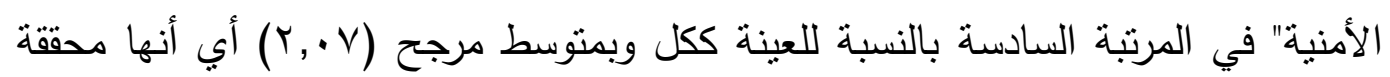

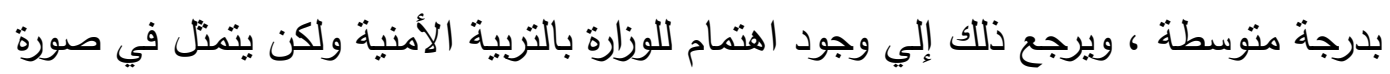

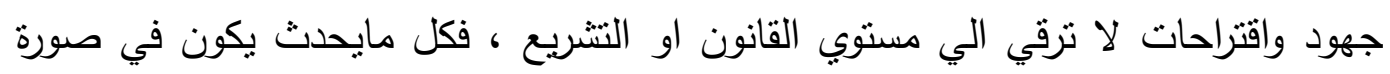

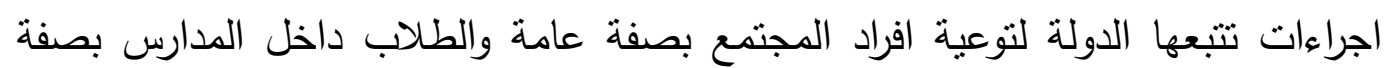

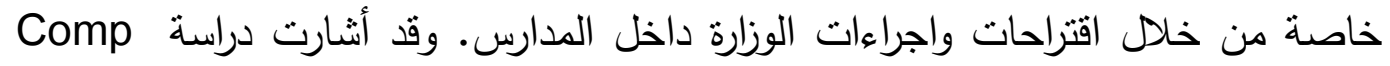

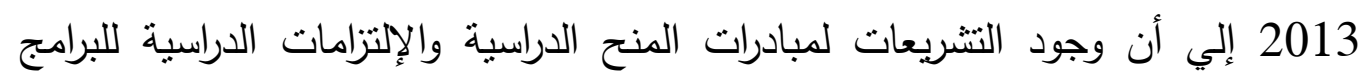

التربية الأمنية بدعم تحقيقها لأهدافها.

جاءت العبارة (0) والتي تتص علي " تتبني الدولة استخدام التكنولوجيا الحديثة لهنع الجريمة والحد

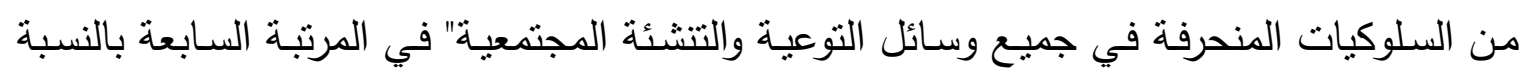

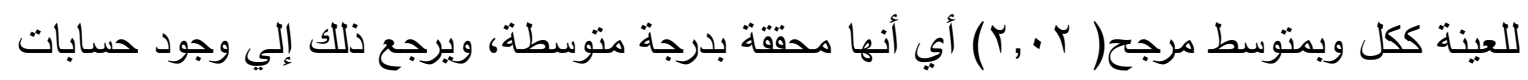

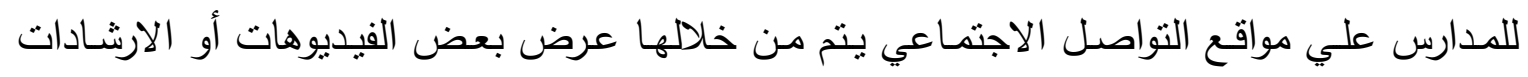
للطلاب لغرس القيم الحسنة والتي قد تسهم في الحد من الانحرافات السلوكية. ثالثا: دور الإدارة المدرسية في تعزيز التربية الأمنية في المدارس الثانوية المصرية وللوصول إلى وجهة نظر أفراد العينة من معلمي المدارس الثانوية (العامة والزراعية والصناعية

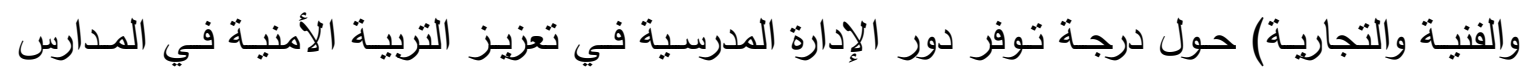
الثانوية، قامت الباحثة بحساب عدد التكرارات والمتوسط لكل عبارة في البعد وفقا لاستجابات أفراد العينة ويوضح جدول (1) (1) استجابتهم لعبارات البعد الخامس. 


\section{جدول (11)}

وجهة نظر أفراد العينة حول دور الإدارة المدرسية في تعزيز التربية الأمنية في المدارس الثانوية.

\begin{tabular}{|c|c|c|c|c|c|c|c|}
\hline \multirow[b]{2}{*}{ الترتيب } & \multirow[b]{2}{*}{ الاتجاه } & \multirow[b]{2}{*}{ 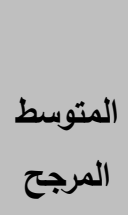 } & \multicolumn{3}{|c|}{ النسبة } & \multirow[b]{2}{*}{ العبارات } & \multirow[b]{2}{*}{ p } \\
\hline & & & غير موافق & 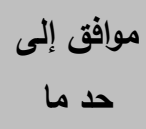 & موافق & & \\
\hline 1 & يتوفر & $r, \cdot \wedge$ & $1 \cdot, v_{1}$ & $r_{\cdot,, r_{0}}$ & OA,QY & داخل المدرسة. إدارة الددرسة علي برامج للتربية الأمنية & 1 \\
\hline$\wedge$ & لا يتوفر & 1,01 & $r, v 1$ & $\mathrm{Y \Psi ,VA}$ & $1 Y, 0$ & تسند المدرسة أدوار ومهام المعلمين المسئولين & $r$ \\
\hline . & يتوفر & r,oq & $v, 1 \varepsilon$ & $r \Upsilon, \cdot V$ & $\checkmark$ ४ $\mathrm{Y}$ & من أجم إدارة الأدرسة نغدرات تستضيف الوعي الأمني بين الطسئولين & $r$ \\
\hline v & يتوفر الي & $r, \cdot r$ & ro & $\{v, 1 \leqslant$ & $Y v, \Lambda 0$ & تشتـــــ إدارة المدرســة علـي معسكرات للطـلاب & $\varepsilon$ \\
\hline ؛ & يتوفر & r,V६ & 1. & $0, v_{1}$ & $\Lambda \varepsilon, Y$ & تطوار الطلاب المدرسة برنـامج الثـرطة الدرسية وتنظم & 0 \\
\hline$r$ & يتوفر & r, YA & $0, V_{1}$ & $1, r, r$ & $\Delta r, q r$ & 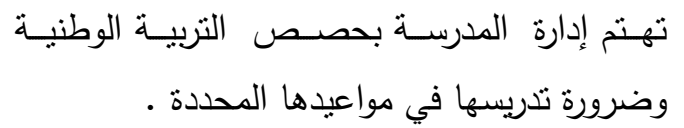 & 7 \\
\hline 1 & يتوفر & r, 94 & $\cdot, v_{1}$ & $r, 0$ & $Q_{4} \uparrow \mathrm{VA}$ & 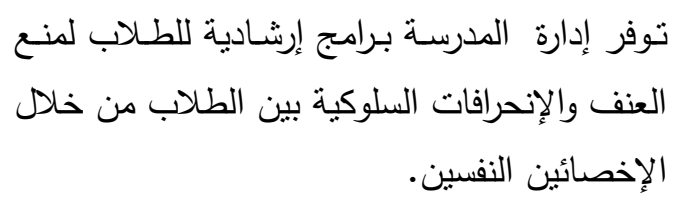 & $v$ \\
\hline$r$ & يتوفر & $r, \wedge 1$ & $0, v 1$ & $\curlyvee, \vee \wedge$ & $\Delta v, 0$. & 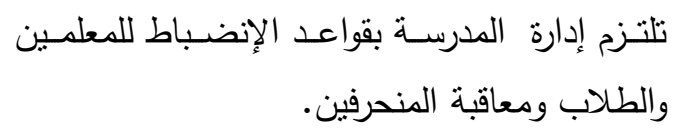 & $\wedge$ \\
\hline & يتو & $r, \sum q$ & & & & البعد ككل & \\
\hline
\end{tabular}

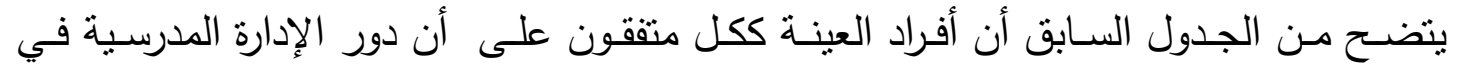

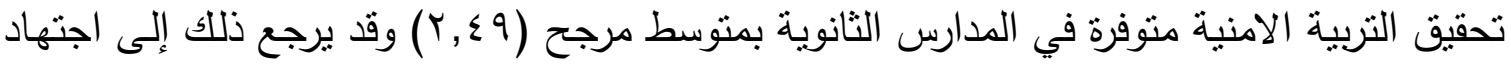

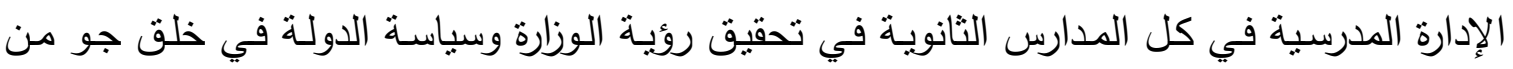

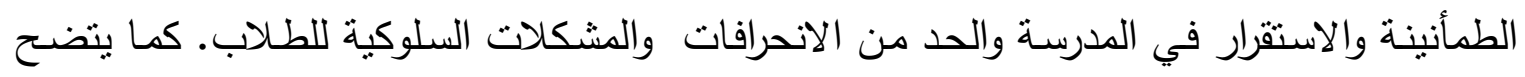

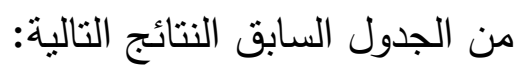

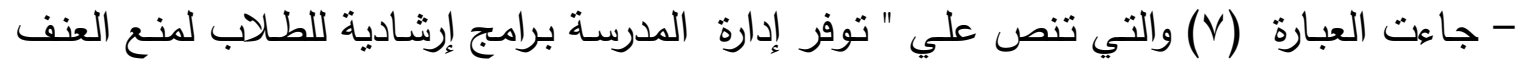

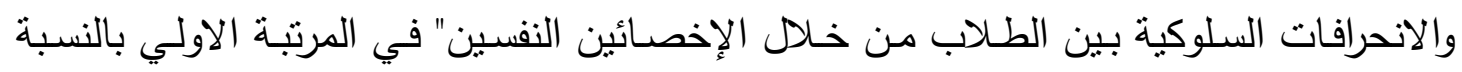

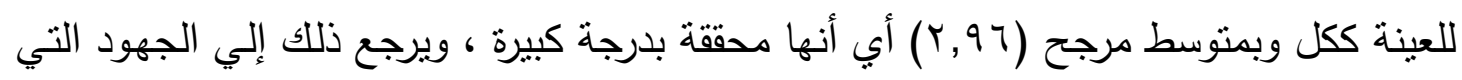


تبذلها الإدارة في تكليف الاخصـائيين الاجتماعين في المدرسـة بعمل ندوات او برامج تدريبية

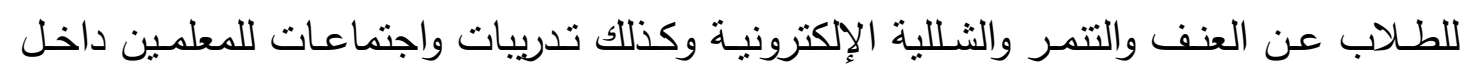
المدرسة للتعرف علي آلية ضبط الصف واحتواء الطلاب المشاكسين. وأثنارت دراسة روان خليل

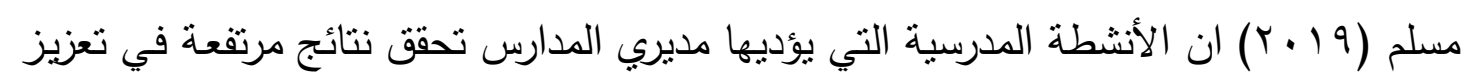
مفاهيم الامن منها الأمن الاجتماعي.

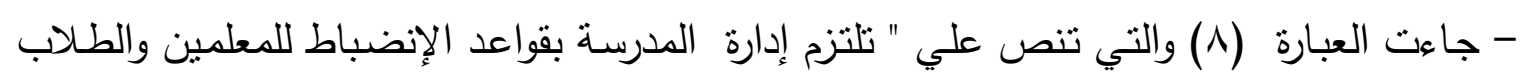

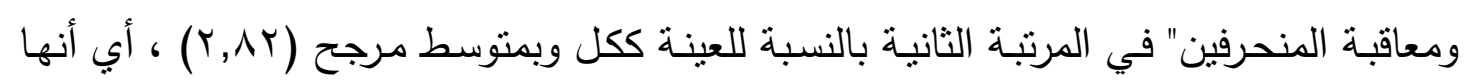

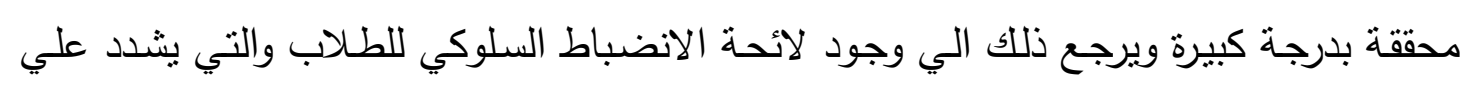
الإدارات المدرسية الالتزام بها وترفق بقواعد العقاب وآلياته. كما يتوفر لابي كل مدرسة لإنة لائحة

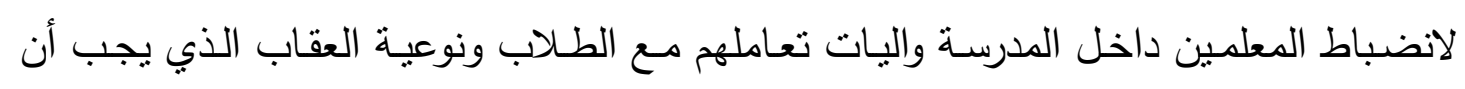
يستخدم . يلإن - جاءت العبارة (ج) والتي تنص علي " تهنم إدارة المدرسة بحصص التربية الوطنية وضرورة

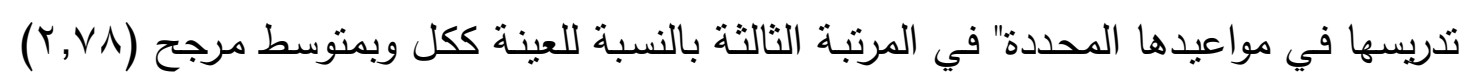

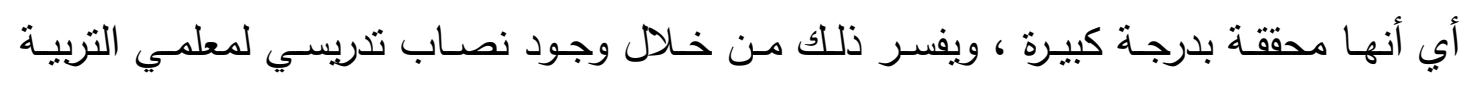
الوطنية داخل الددرسة وحصص محددة داخل اليوم الدراسي وتتتوع الحصص من الفترة الأولي

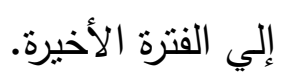

- جاءت العبارة (0) والتي تنص علي " تطبق المدرسة برنـامج الثنرطة المدرسية وتنظم أدوار

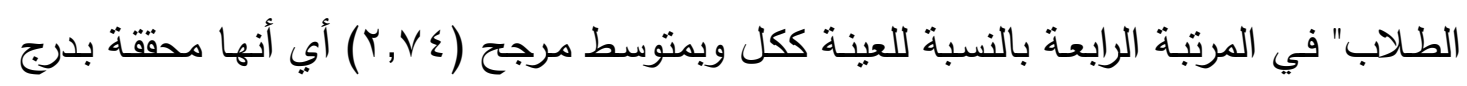

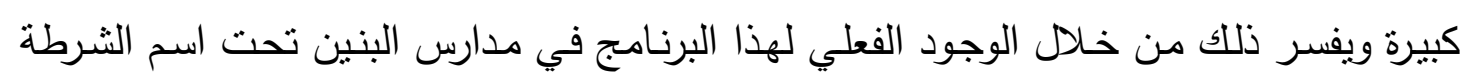

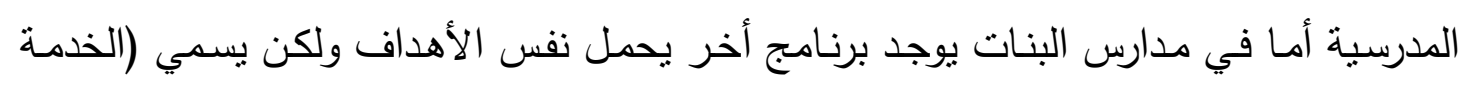

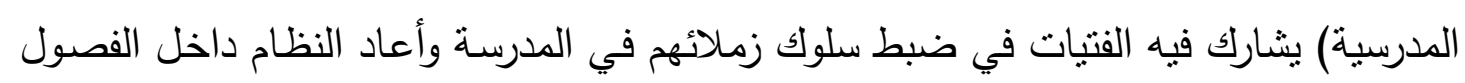

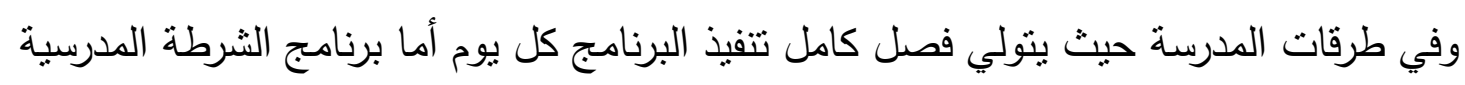
في مدارس البنين تقوم بتنفيذه جماعة الثرطة المدرسية

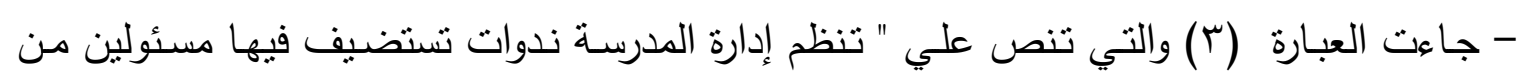

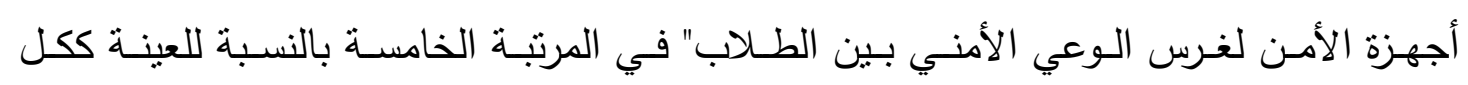

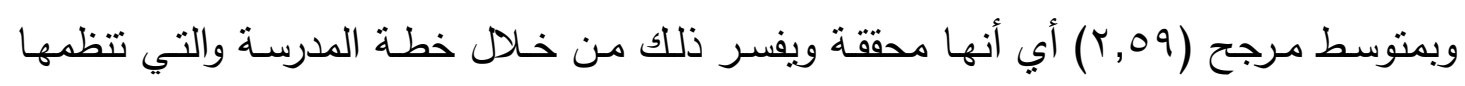

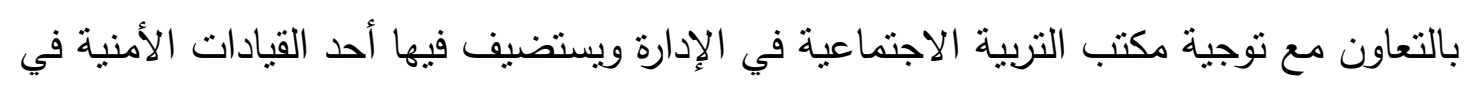

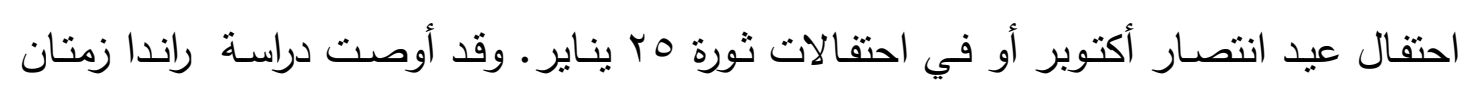

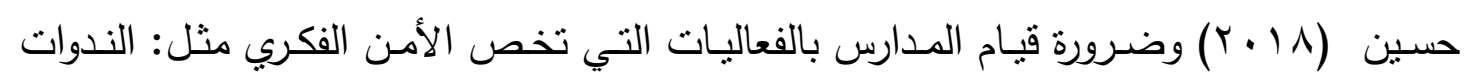


والمسرحيات والخطابة والدورات لنشر المفاهيم الأمنية وتعزيز الأمن الفكري بصفة خاصـة في

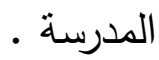

- جاءت العبارة ( () والتي تنص علي " تشرف إدارة الددرسـة علي برامج للتربيـة الأمنيـة داخل

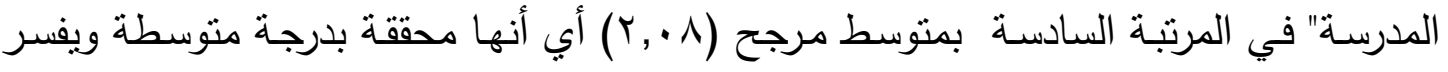

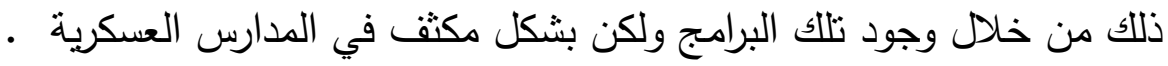
- حازت علي العبارة (乏) والتي تنص علي " تشرف إدارة المدرسة علي معسكرات للطلاب داخل

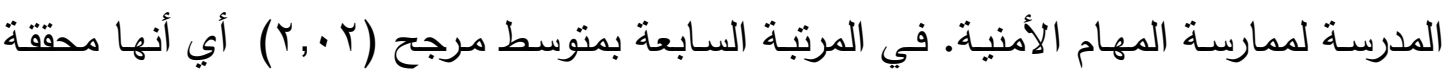
بدرجة متوسطة ويفسر ذلك وجود تلك المعسكرات في الدارس العسكرية وبعض مدارس الثانوية

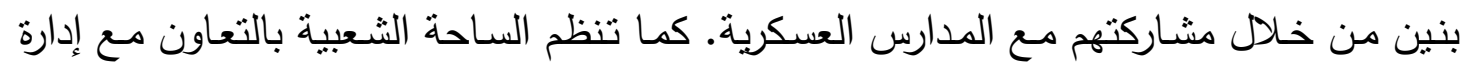
المدرسة الثانوية للبنين معسكر داخل الساحة الثعبية لممارسة التنريبات العسكرية والرياضية . - حازت العبارة (r) والتي تنص علي " تسـد المدرسـة أدوار ومهام المعلمين المسئولين عن

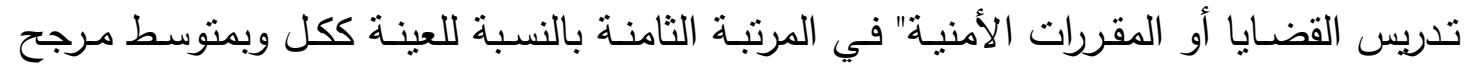
(1,01) أي أنها غير محققة ويفسر ذلك بانه لايوجد مقرر أمني مستقل للتربية الأمنية وإنما يتم

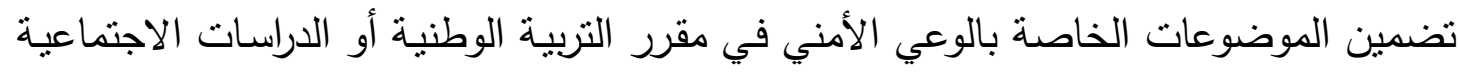
وكذلك دروس في التربية الدينية ولا يطالب أب معلم بالتخلي عن مقرره مهما كان مقرر فرعي.

رابعا: دور المعلم في تعزيز التربية الأمنية في المدارس الثانوية المصرية وللوصول إلى وجهة نظر أفراد العينة من معلمي المدارس الثانوية (العامة والزراعية والصناعية والفنية والتجارية) حول درجة توفر دور المعلم في تعزيز التربية الأمنية_في المدارس الثانوية، قامت

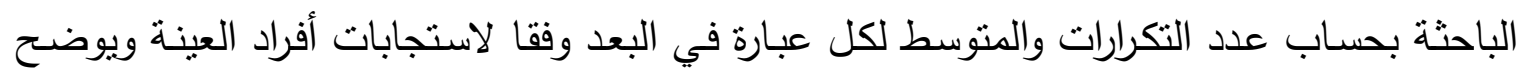
جدول (r ( ) استجابتهم لعبارات البعد السادس. 


\section{جدول (r)}

وجهة نظر أفراد العينة حول دور المعلم في تعزيز التربية الأمنية في المدارس الثانوية.

\begin{tabular}{|c|c|c|c|c|c|c|c|}
\hline \multirow[b]{2}{*}{ الترتيب } & \multirow[b]{2}{*}{ الاتجاه } & \multirow[b]{2}{*}{ 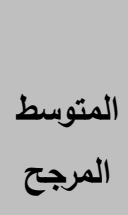 } & \multicolumn{3}{|c|}{ النسبة } & \multirow[b]{2}{*}{ العبارات } & \\
\hline & & & غوافق & 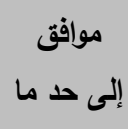 & موافق & & p \\
\hline r & يتوفر & ५.94 & $1, \varepsilon r$ & $1, \cdot v$ & qv, ०. & 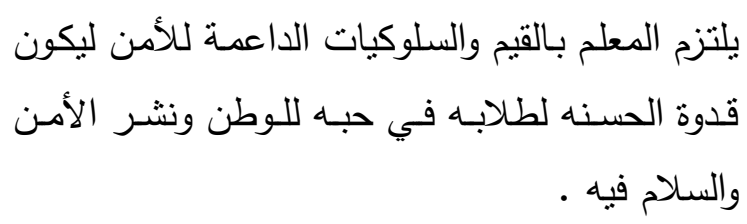 & \\
\hline v & لي الي حفر & $r, 1 \wedge$ & $V, I \varepsilon$ & $4, V$ & $r q, . V$ & 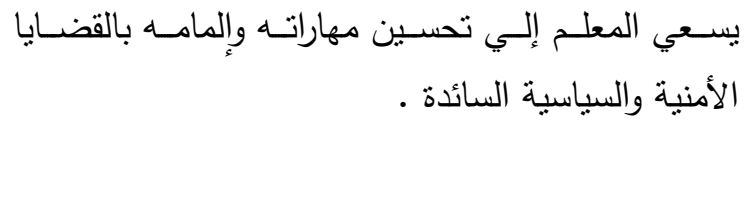 & $r$ \\
\hline 1 & يتوفر & r.99 & . & $\cdot, v_{1}$ & $৭ ৭, \curlyvee \wedge$ & 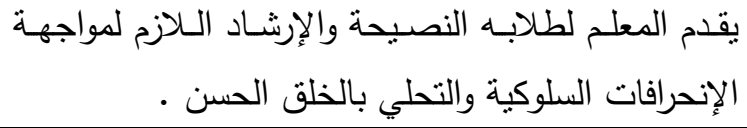 & $r$ \\
\hline$\varepsilon$ & يتوفر & $r, \wedge \Gamma$ & 0 & $7, \cdot V$ & A८,QY & 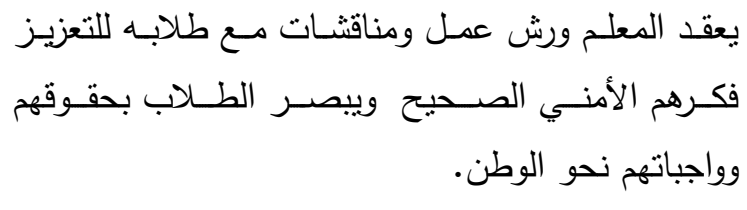 & $\varepsilon$ \\
\hline 0 & يتوفر & $r, v_{1}$ & $\Lambda, Q Y$ & $1,, v$. & $\Lambda_{\cdot}, \boldsymbol{r}$. & 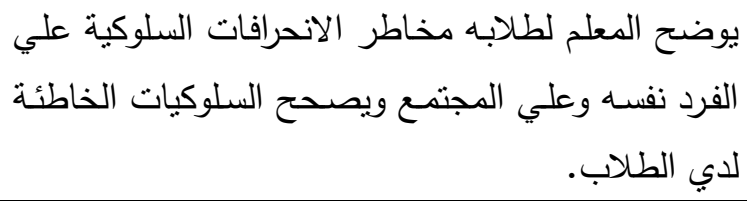 & 0 \\
\hline 7 & يتوفر & r. & $\Lambda, q \varphi$ & $18, .8$ & vo & 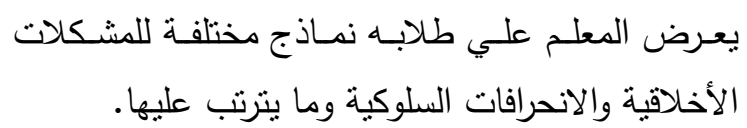 & 7 \\
\hline 1 & يتوفر & $r, 14$ & $\{, \uparrow \xi$ & $r r, q Y$ & $V_{1}, \varepsilon r$ & يتعاون المعلم مع الجهات الأمنية لحفظ الأمن وتوعية & v \\
\hline$r$ & يتوفر & $r, 90$ & $\cdot, v_{1}$ & $r, \wedge 0$ & $94, \& Y$ & 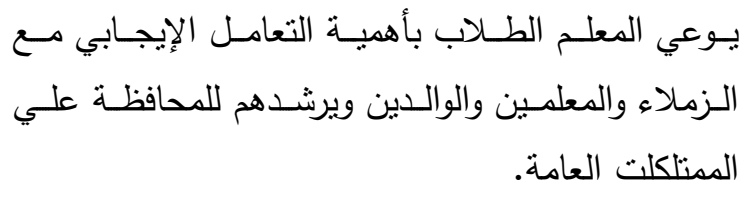 & \\
\hline \multicolumn{2}{|c|}{ يتوفر } & $Y, V \leqslant$ & & & & البعد ككل & \\
\hline
\end{tabular}

يتضـح من الجدول السـابق أن أفراد العينـة ككل متفقون على أن دور المعلم لتعزيز التربيـة

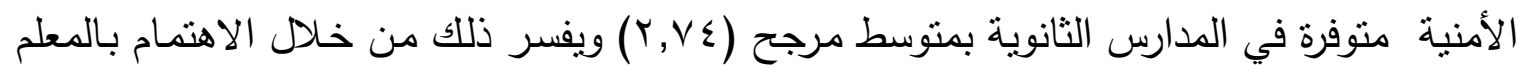
في الأونة الأخيرة باعتباره الناقل والممثل للقيم في المدرسة ويلقي معلم المرحلة الثانوية عناية خاصة حيث انه يتعامل مع طلاب في مرحلة عمرية حرجة ولذا يتلقي تدريبات عديدة عن التدريس الفعال 
وأليات ضبط الصف، والتفاعل الصفي والعلاقات الإنسانبة، كماسلكت الوزارة منهجا جديدا في تقويم

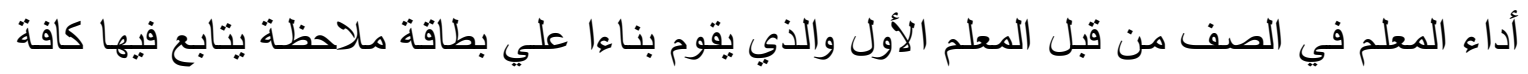
سلوكيات الصفية للمعلم وكذللك الموجة الخاص بـالمقرر ـ كما يتضـح من الجدول السـابق النتائج

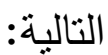

- جاعت العبارة (r) والتي تنص علي " يقدم المعلم لطلابـه النصيحة والإرشـاد اللازم لمواجهة الإنحرافات السلوكية والتحلي بالخلق الحسن"' في المرتبة الأولي بالنسبة للعينة ككل وبمتوسط لإنها

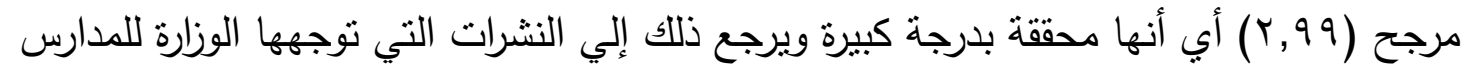

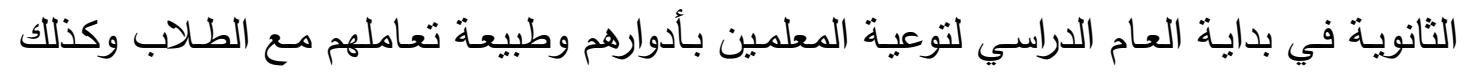
العقوبات التاديبية لكل من يصدر سلوكا منحرفا داخل المدرسة .

- - جاءت العبارة ( () والتي تتص علي " يلتزم المعلم بالقيم والسلوكيات الداعمة للأمن ليكون قدوة

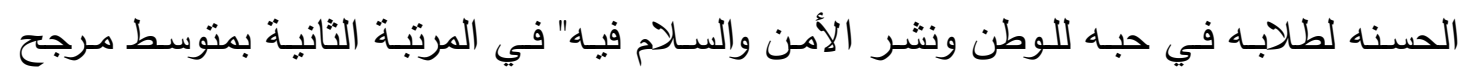

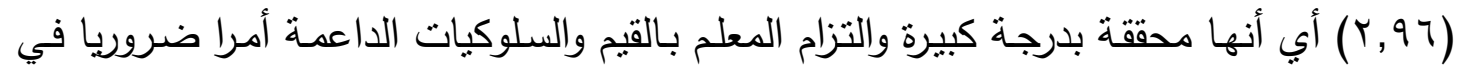

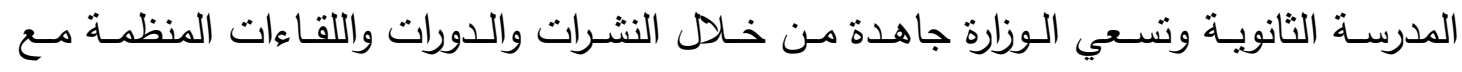
الموجهين والمعلمين إلي توعية وارشاد المعلم بالعديد من القيم منها الداعمة للامن والاستقرار

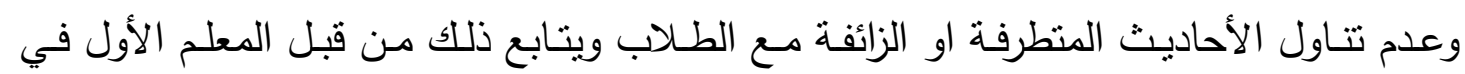

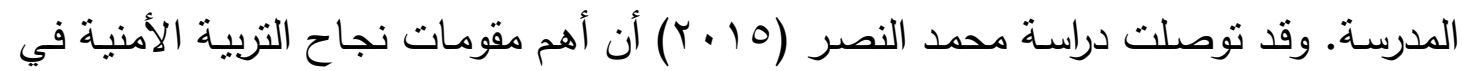

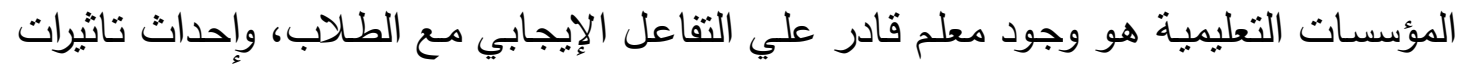
إيجابية في سلوكهم •

- جاءت العبارة (^) والتي تتص علي " يوعي المعلم الطلاب بأهمية التعامل الإيجابي مع الزملاء

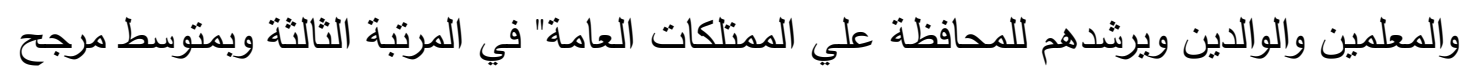

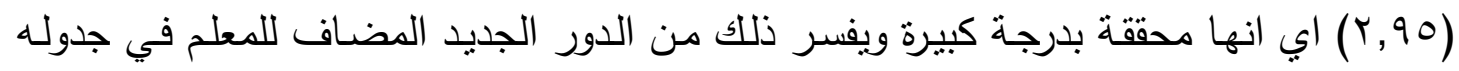

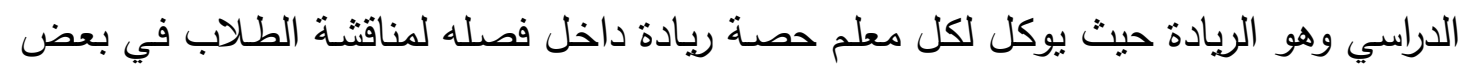
القضايا المدرسية والمجتمعية ومنها القضايا الأمنية وفقا لتوجيهات الوزارة . - حازت العبارة (ع) والتي تتص علي " يعقد المعلم ورش عمل ومناقثات مع طلابه للتعزيز فكرهم

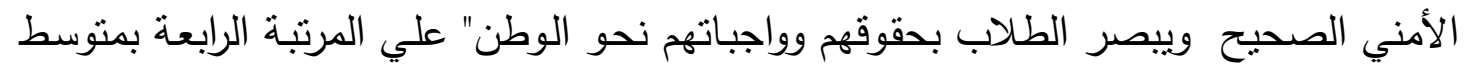

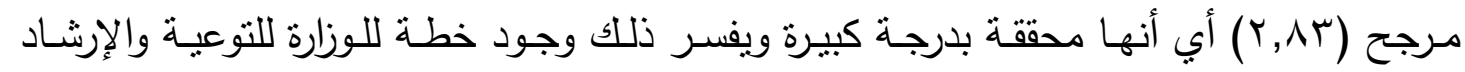

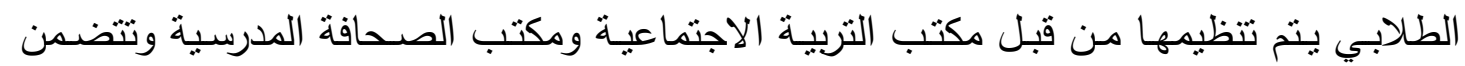

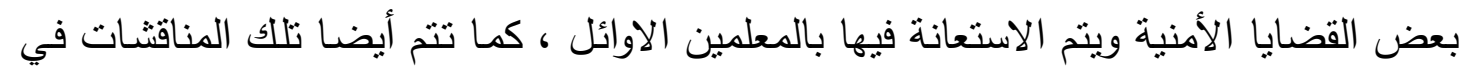

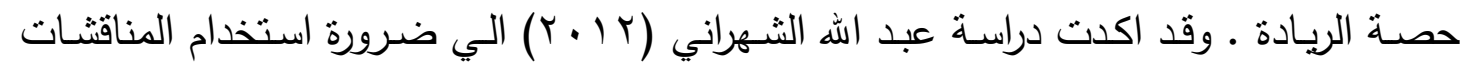


وغيرها من الانشطة التي يستطيع المعلم من خلالها الكثف عن أراء الطلاب ومحاولة تعديها وتكوين اتجاهات إيجابية نحو قضايا الأمن.

- حازت العبارة (0) والتي تنص علي " يوضح المعلم لطلابه مخاطر الانحرافات السلوكية علي

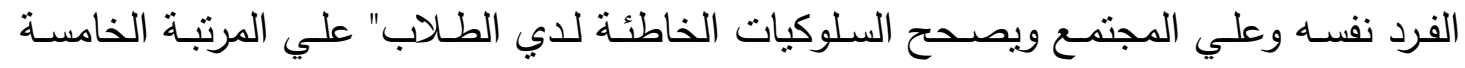
وبمتوسط مرجح (Y,Y) اي انها محقةة حيث يتم ذلك ايضا ضمن توصيف حصص الريادة

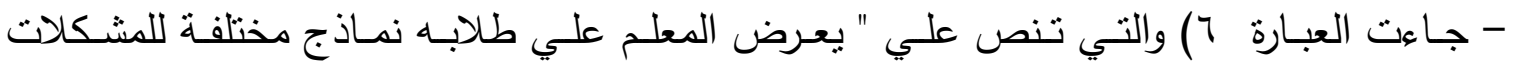

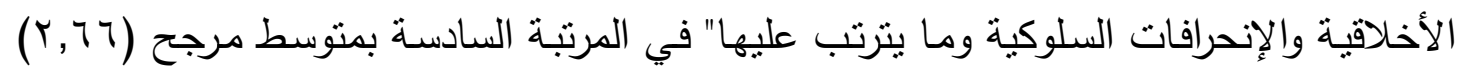

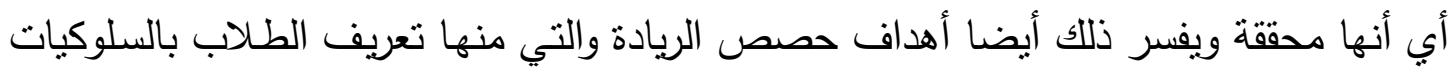
الخاطئة .

- جاءت أيضـا العبارة (V) والتي تنص علي " يتعاون المعلم مـع الجهات الأمنية لحفظ الأمن

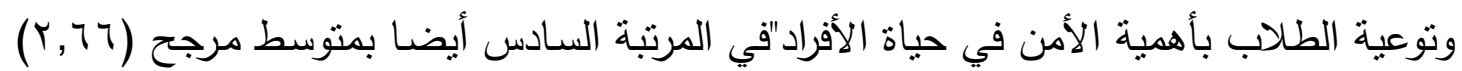
ويفسر ذللك

أن كل دور يقوم به المعلم لضبط سلوكيات الطلاب وتوعيتهم بالمخاطر التي تتتج عن الانحراف الإخلالي يعتبر مساعدة لإرساء الأمن والاستقرار ويعتبر بذلك مساندا لأهداف الجهات الأمنية . - حازت العبارة (r) والتي تتص علي " يسعي المعلم إلي تحسين مهاراته وإلمامه بالقضايا الأمنية

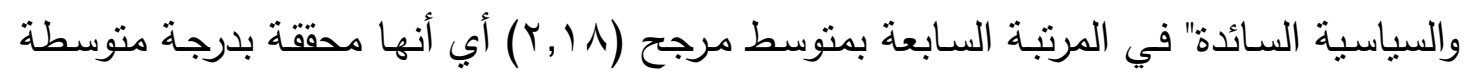

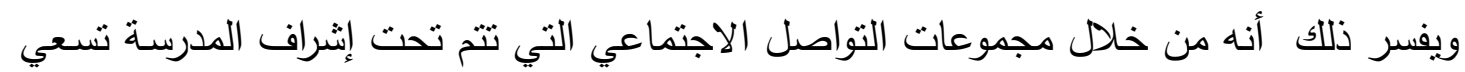

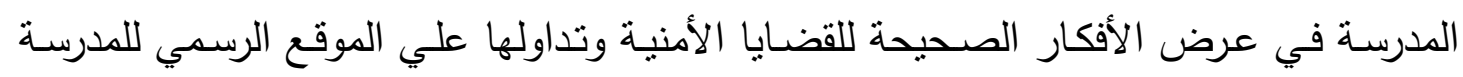
ومحاولة مناقتنها في إطار بناء.

نتائج الاراسة توصلت الدراسة النظرية والميدانية إلى عدة نتائج من أهمها:-

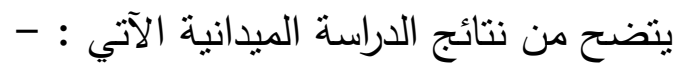

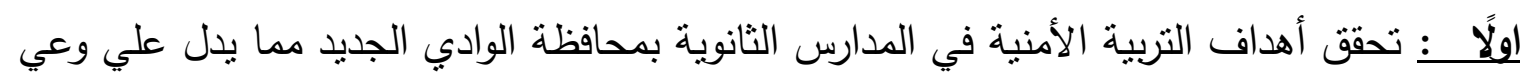

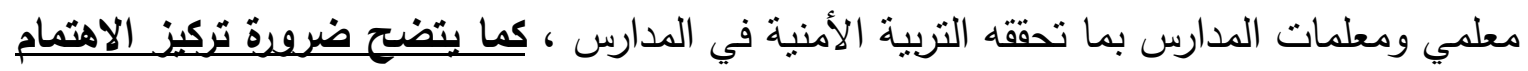
علي الاتي: - ن معلي - - تدريب الطلاب في المرحلة الثانوية علي آليات الحماية والدفاع عن النفس من المجرمين والمنحرفين من خلال إعداد دورات للطلاب بالتعاون مع الهيئات الأمنية بالمحافظة. 
- الاهتمام بالمشاركة المجتمعية بين المؤسسات التربوية والمؤسسات الأمنية من خلال تحديد آليات وبرامج للمشاركة المجتمعية التي تدعم أهداف التربية الأمنية .

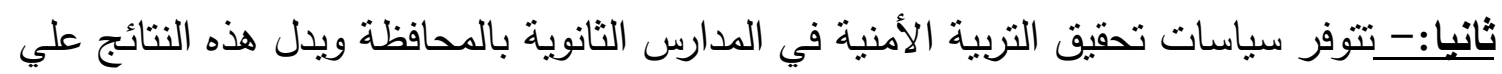

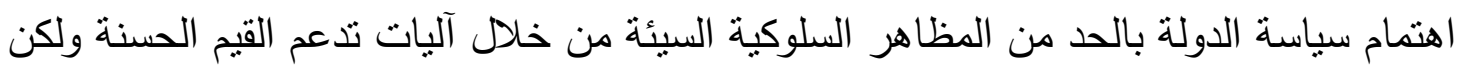

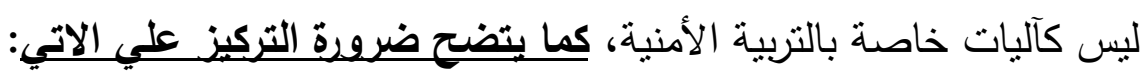
- اهتمام السياسة التعليمية بقضية الأمن وإحترام الحقوق والممتلكات العامة في الدولة . - سن التشريعات اللازمة لتتفيذ برامج ومبادرات التربية الأمنية .

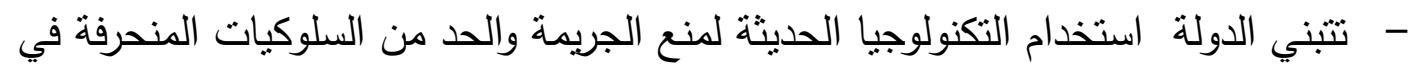
جميع وسائل التوعية والتنشئة المجتمعية . تتوفر دور الإدارة المدرسية في تعزيز التربية الأمنية في الددارس الثانوية بالمحافظة ويتضح ذلانك من الاجراءات التي تتخذها إدارات المدارس لتحقيق الأمن والاستقرار داخل الددرسة، كما ينبغى تركيز الإنيز الاهنمام على الآتي: - إثراف إدارة المدرسة علي برامج للتربية الأمنية داخل المدرسة. - - - إسناد المدرسة أدوار ومهام المعلمين المسئولين عن تدريس القضايا أو المقررات الأمنية .

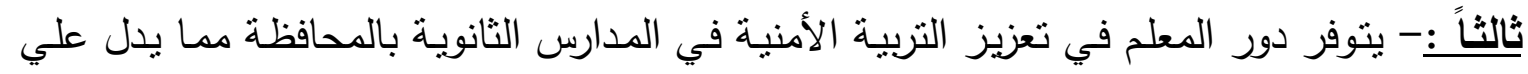

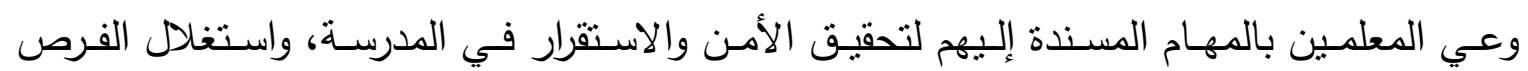
البسيطة المتاحة لتوعية الطلاب بأهمية السلوكيات الجيدة وأضرار العنف والانحرافات السلوكية، كميا ينبفي تركيز الاهتمام علي الاتي: - تحسين مهارات المعلم وإلمامه بالقضايا الأمنية والسياسية السائدة . توصيات الدراسة

في ضوء ما نوصلت إليه الدراسة الميدانية من نتائج توصي الباحثة بما يلي:- ت تطوير دور المعلم بما يتتاسب وتحقيق أهداف التربية الأمنية .

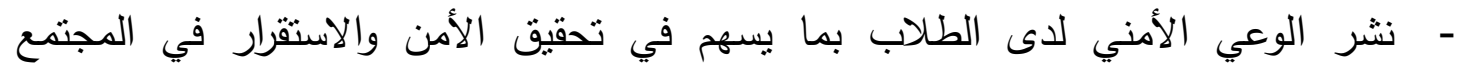

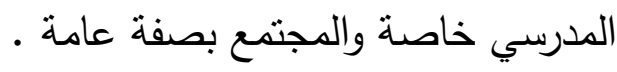

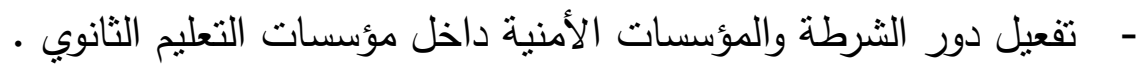

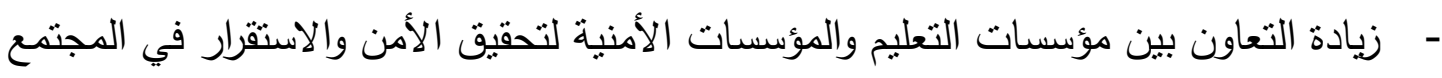


- اكساب الطلاب المهارات الحياتية المناسبة والكفاءات العقلية والإجتماعية لتمكين الفرد من

العيش في المجتمع والمساهمة في تتميته .

- 


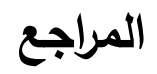 \\ أولًا : المراجع العربية}

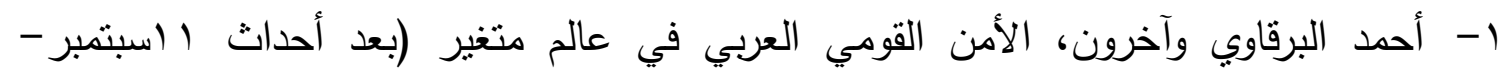

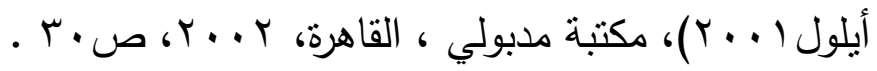

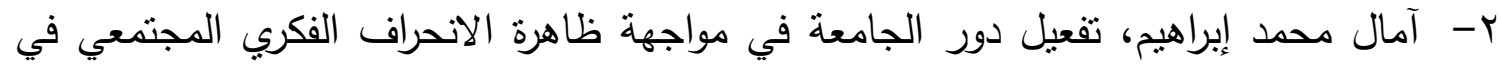
ضوء منطلبات تحقيق الأمن الفكري في الثريعة الإسلامية : دراسة تحليلي،مجلة كلية

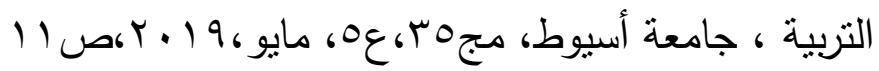

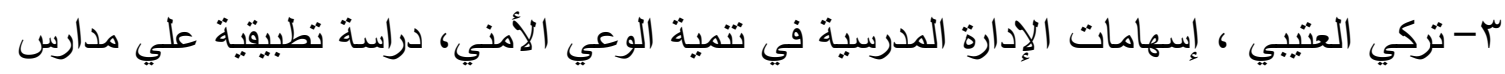

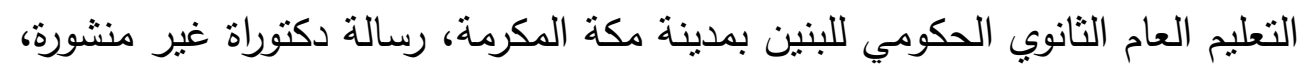

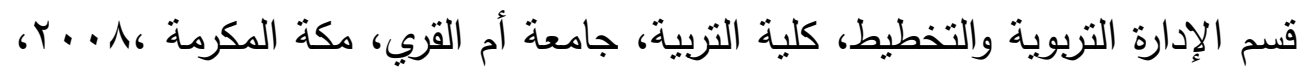
. V

ع-حسن الحارث و واديني غسان، علم النفس الأمني ، بيروت، الدار العربية للعلوم ،7... الحقيل، سليمان عبد الرحمن، الإدارة المدرسية وتعبئة قواها البشرية في المملكة

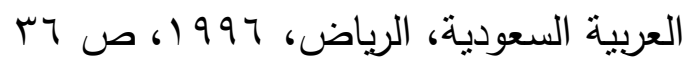

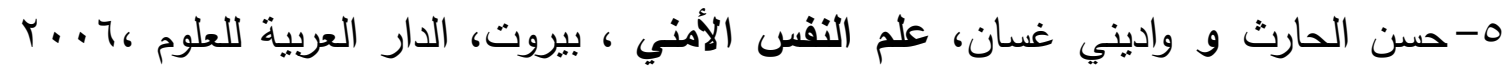

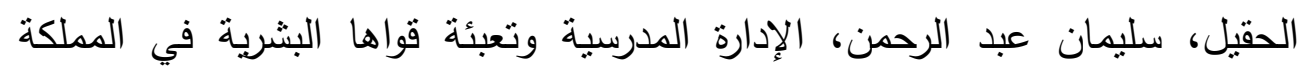

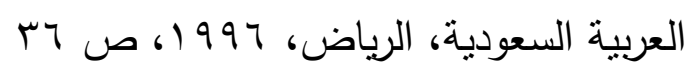
צ-حسن شحاته،، المنهج الإسلامي للأمن والتنمية، خواطر إسلامية، القاهرة، جامعة الأزهر .

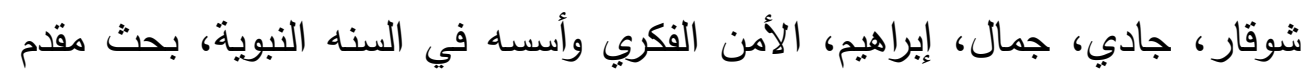

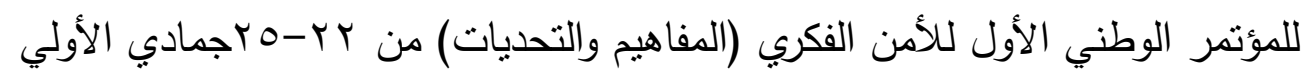

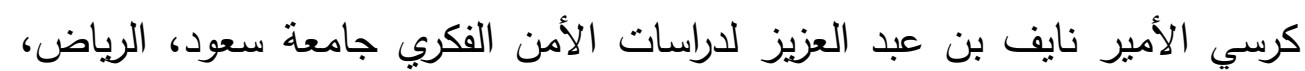

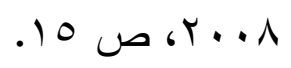

V-حسن محمد الزهراني، الأمن الفكري لاي الطلاب مظاهره وصوره وطرق الوصول إليه، مجلة

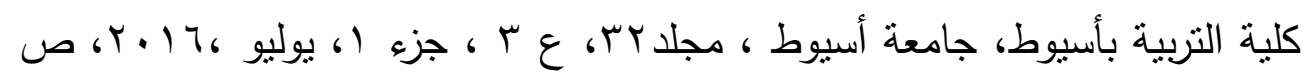

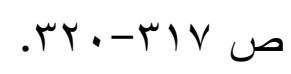
^-داود حلسو فايز شلدن، ، الددرسة الفعالة ودورها في تحقيق سمات البيئة التعليمية المشجعة علي الإنضباط السلوكي من وجهة نظر معلمي المرحلة الثانوية، مجلة الجامعة

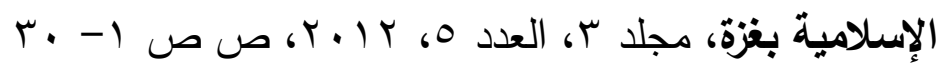


9-رشاد عبد اللطيف، ، تنمية المجتمع المحلي، الإسكندرية، دار الوفاء لدنبا الطباعة

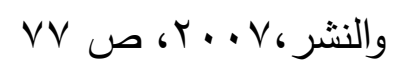

• 1-سليم الهذلي، درجة إسهام الإدارة المدرسية في تحقيق أهداف الأمن الفكري لدي طلاب

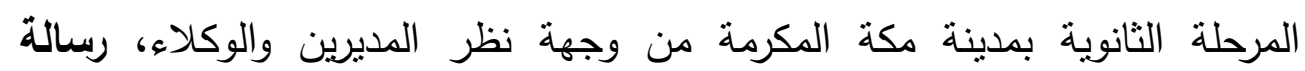

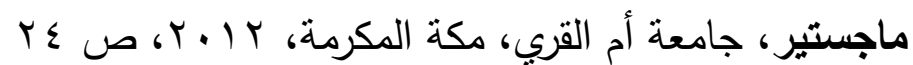

1 11-عبد الرحمن بن عبد الوهاب البابطين ، قضايا في التعليم الثانوي العام في المملكة العربية

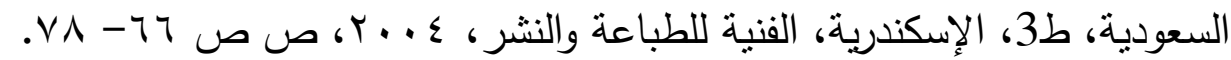

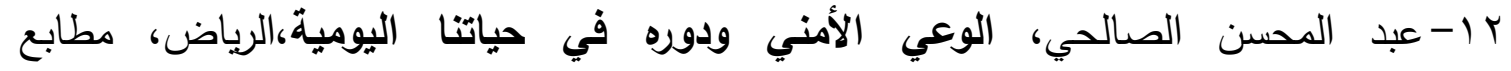

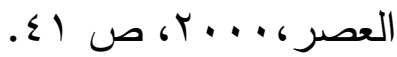

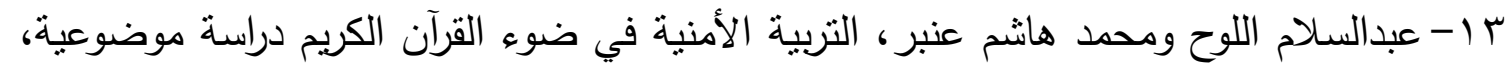

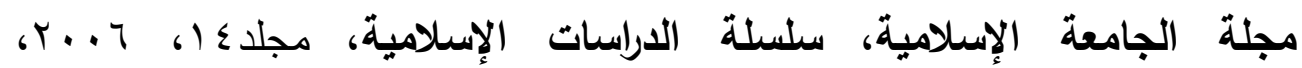

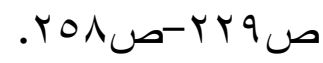

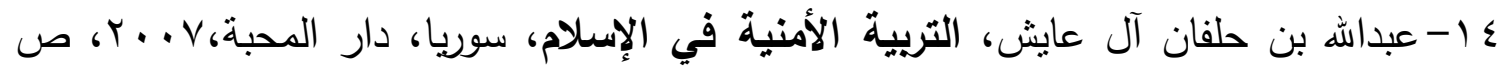
r r

10-فهر سلطان السلطان، التربية الأمنية وأمكانية تطبيقها في المؤسسات التعليمية ، بحث منشور مركز البحوث التربوية ،جامعة الملك سعود، 9 . . ب .

7 ا-محمد منشاوي، رأي الجمهور في الثرطة المجتمعية، ورقة عمل مقدمة لندوة مفهوم الشرطة

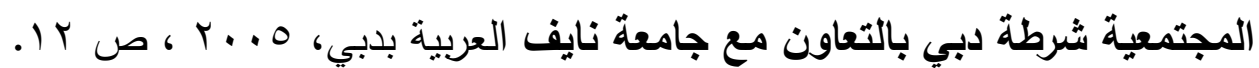

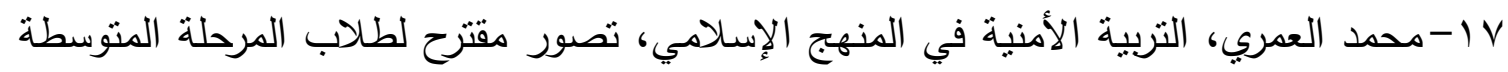

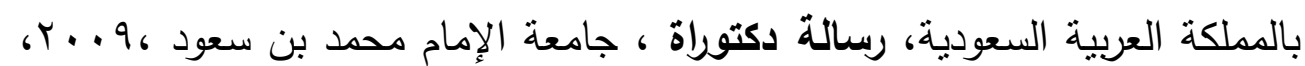
ص ص 19

11-محمد النصر حسن، رؤية تربوية مقترحة لمنطلبات تحقيق التربية الأمنية بمرحلة التعليم

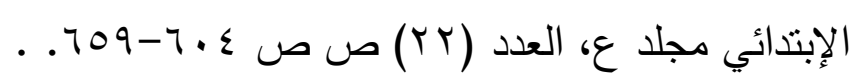

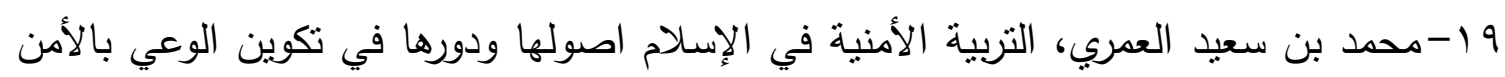

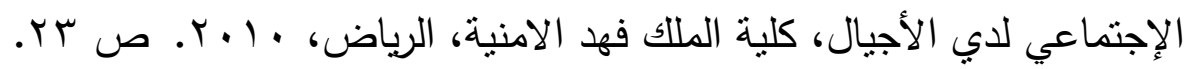

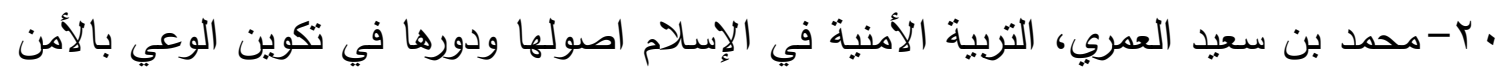

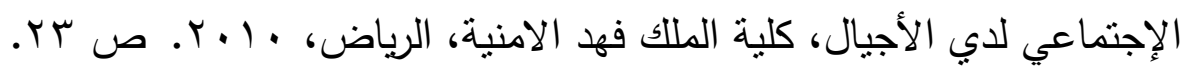




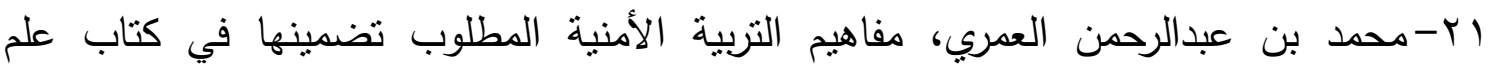

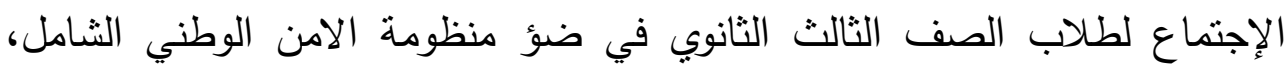
رسالة ماجيستير غير منشورة، قسم المناهج وطرق التدريس، جامعة ام القري، مكة الإنة

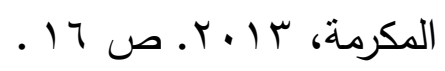

r ب-محد بن عبدالرحمن العمري، مفاهيم التربية الأمنية المطلوب تضمينها في كتاب علم

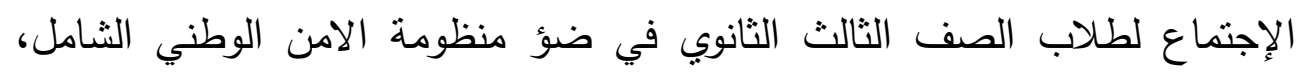
رسالة ماجيستير غير منشورة، قسم المناهج وطرق التدريس، جامعة ام القري، مكة

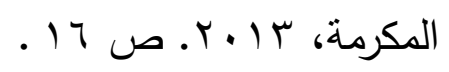

بr-محمد عبد الرؤف عطية، التعليم وأزمة الهوية الثقافية، مؤسسة طيبة للطبع والنشر ، القاهرة،

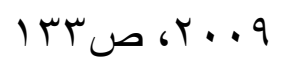

ع ب-محمدالمنشاوي ، رأي الجمهور في الثرطة الهتمعية، ورقة عمل مقدمة لندوة مفهوم الثرطة

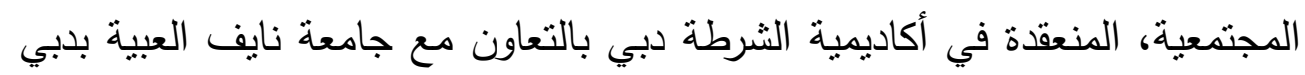

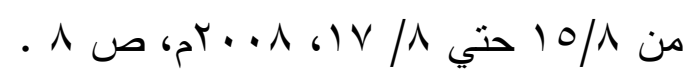

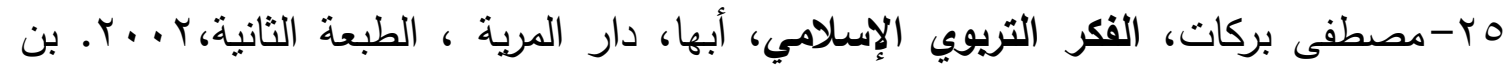

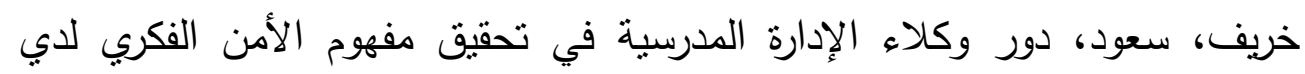

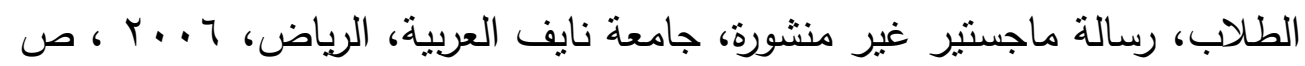

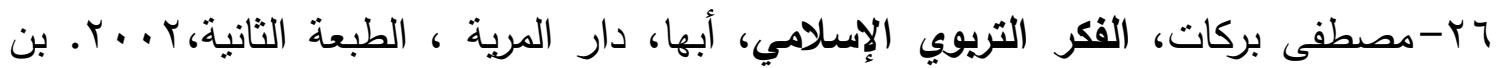

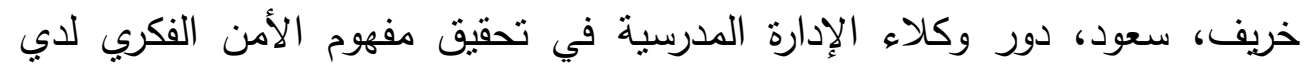

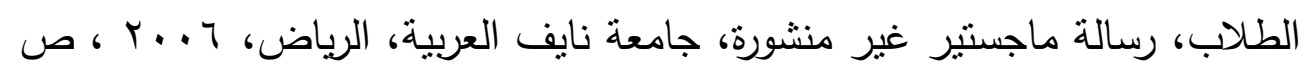
.$v$

VV-معتز عبدالحميد، ، تصور مستقبلي للتوعية الأمنية في المناهج الدراسية، القاهرة، دار

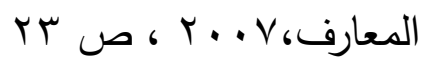

^ץ-معتز عبدالحميد، تصور مستقبلي للتوعية الأمنية في المناهج الدراسية، القاهرة، دار

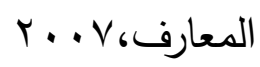

وץ-مكتب التربية العربي بدول الخليج، الأهداف التربوية والأسس العامة للمناهج بدول الخليج

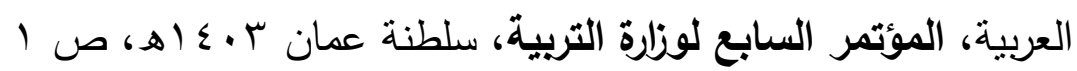




$$
\text { ثانيًا :- المراجع الأجنبية . }
$$

30- Bradshaw, Chris William): Designing a homeland security curriculum in American higher education, Dissertation Abstracts International, Pro Quest 902491019 Ann Arbor, Texas, United States, 2011, P.15.

31- Comp, D. J.: The National Security Education Program and its service requirement: An exploratory study of what areas of government and for what duration National Security Education Program recipients have worked 2013)

32- Purkey, w ,creating safe schools through Invitational Education ,ERIC Identifi er ;ED $\leqslant$ r०१ะ५. Pp.197-198. 